UNIVERSIDADE DE SÃO PAULO

FABIANA NOGUEIRA CHAVES

\title{
As Festas Populares e o Contexto Midiático: Lavras Novas e o futuro de sua identidade cultural.
}

São Paulo 
FABIANA NOGUEIRA CHAVES

\section{As Festas Populares e o Contexto \\ Midiático: Lavras Novas e o futuro de sua identidade cultural.}

Dissertação de Mestrado apresentada por Fabiana Nogueira Chaves, sob orientação do Prof. Dr. Dennis de Oliveira, como exigência parcial para obtenção do título de mestre em Ciências da Comunicação pela Escola de Comunicação e Artes da Universidade de São Paulo - USP.

Universidade de São Paulo Escola de Comunicação e Artes 
Autorizo a reprodução e divulgação total ou parcial deste trabalho, por qualquer meio convencional ou eletrônico, para fins de estudo e pesquisa desde que citada a fonte.

\author{
Catalogação na publicação \\ Serviço de Biblioteca e Documentação
}

Escola de Comunicações e Artes da Universidade de São Paulo

Chaves, Fabiana Nogueira

As festas populares e o contexto midiático : Lavras Novas e o futuro de sua identidade cultural / Fabiana Nogueira Chaves - São Paulo : F. N. Chaves, 2011.

$140 \mathrm{p}$.

Dissertação (Mestrado) - Escola de Comunicações e Artes / Universidade de São Paulo.

Orientador: Prof. Dr. Dennis de Oliveira

1. Lavras Novas 2. Festas populares subalternas 3. Identidade cultural

4. Turismo 5. Meios de comunicação de massa.

CDD 21.ed. - 301.16 
Nome: CHAVES, Fabiana Nogueira

Título: As Festas populares e o contexto midiático: Lavras Novas e o futuro de sua identidade cultural.

Dissertação apresentada à Escola de Comunicação e Artes da Universidade de São Paulo para obtenção do título de mestre em Ciências da Comunicação.

Aprovado em:

Banca Examinadora:

Prof. Dr.

Instituição:

Julgamento:

Assinatura:

Prof. Dr.

Julgamento: Instituição:

Assinatura:

Prof. Dr.

Julgamento:

Instituição:

Assinatura: 
Ao maior patrimônio de

Lavras Novas: sua gente. 


\section{AGRADECIMENTOS}

Agradeço em primeiro lugar a Deus, que possibilitou que eu concluísse mais esta etapa em minha vida.

À Professora Maria Nazareth Ferreira, que iniciou o trabalho de orientação e foi a primeira pessoa a acreditar nesta pesquisa. Agradeço muito a ela pelos ensinamentos, pelo empenho e dedicação a este trabalho.

Ao professor Dennis de Oliveira que aceitou com muito boa vontade continuar com o trabalho de orientação iniciado pela professora Nazareth. A ele meu profundo agradecimento.

A meus pais que sempre me deram força e possibilitaram que eu concluísse esta dissertação.

A meu companheiro e amigo Maurício, que muito contribuiu para a execução deste trabalho e me ajudou a ter ânimo em momentos difíceis.

À Comunidade de Lavras Novas, pelo acolhimento, carinho e colaboração, pois sem a voz da população local esta pesquisa se tornaria impossível.

À Fabiana Amaral, Moisés dos Santos e Stela Guimarães.

Aos professores Celso Frederico, Dilma de Mello Silva, Ciro Marcondes Filho pelas ótimas aulas e pelo aprendizado adquirido. Ensinamentos como estes muito ajudaram na execução deste trabalho, possibilitaram a abertura de novos horizontes e ampliaram a projeção da pesquisa.

Agradeço também aos amigos Thiago Padovan, Bibiana Almeida e Vivian Fernandes, com as quais pude dividir momentos de dificuldade e de alegria. 


\section{SUMÁRIO}

Resumo ….......................................................................................................................... 09

Introdução ............................................................................................................................10

Capítulo I: Lavras Novas: Das minas de ouro aos festivais de vinho ............................17

1.1 - A formação do distrito de Lavras Novas............................................................ 17

1.2 - A formação étnica do distrito de Lavras Novas: Entre negros, portugueses e índios carijós ................................................................................ 22

1.3 - O legado cultural: A marujada que é tocada por quem

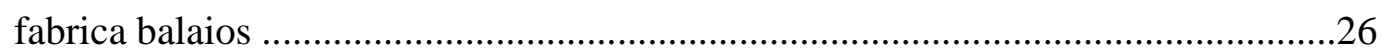

1.4 - A chegada da Luz elétrica, da mídia e a transformação da região em pólo

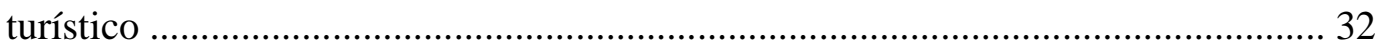

Capítulo II: Identidade Cultural, mídia e turismo: As festas populares subalternas entre a resistência e a reificação .............................................................................................................37

2.1 - O Hegemônico e o subalterno: Uma análise considerando o caráter

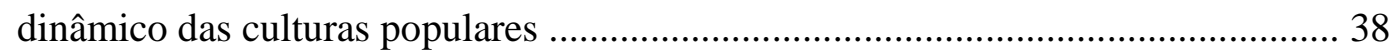

2.2 - As festas populares como objeto de estudo .....................................................42

2.3 - Turismo predatório $\mathrm{X}$ turismo emancipador: As pequenas

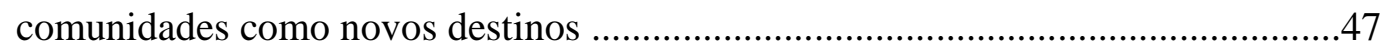

2.3.1- Turismo cultural e identidade .........................................................47

2.3.2 - O turismo predatório e sua relação com a descaracterização da

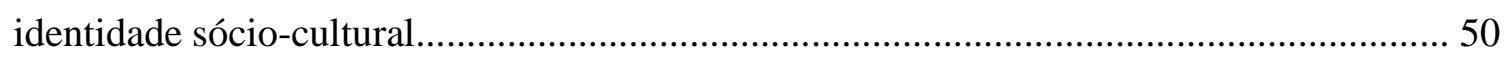

2.3.3 - Possibilidades rumo a um turismo emancipador.............................53

2.4 - A arte das culturas populares subalternas como elementos de

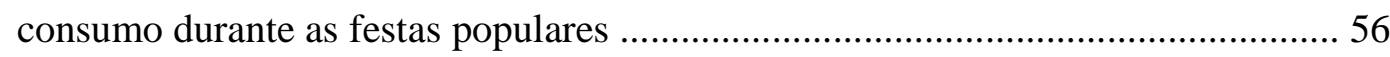

2.5 - Festas populares subalternas, mídia e turismo: A criação da imagem de lugares autônomos ............................................................................ 61 
2.6 - A oralidade como frente de resistência ao hegemônico no contexto das culturas populares subalternas

Capítulo III: Identidade Cultural, mídia e turismo: As festas populares subalternas entre a resistência e a reificação. .75

3.1 - O sagrado e o profano como raiz da festa brasileira.........................................76

3.2 - A Festa do Divino e de Nossa Senhora dos Prazeres.......................................82

3.2.1 - Festa do Divino Espírito Santo.........................................................82

3.2.2 - A Festa de Nossa senhora dos Prazeres...........................................84

3.2.3 - Nossa Senhora dos Prazeres e o Divino: duas celebrações em uma

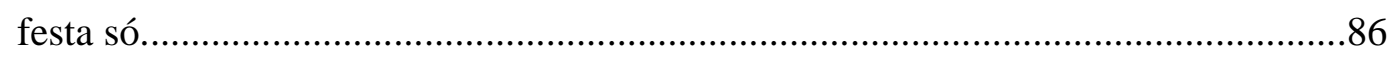

3.3 - A Semana Santa e a Encomendação das Almas em Lavras Novas..................93

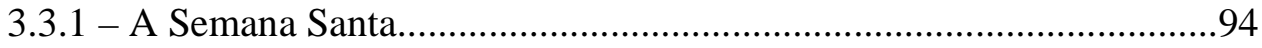

3.3.2 - A semana Santa e a Encomendação das Almas em Lavras Novas ...95

Capítulo IV: As festas populares e suas inter-relações: A pesquisa, a comunidade e os

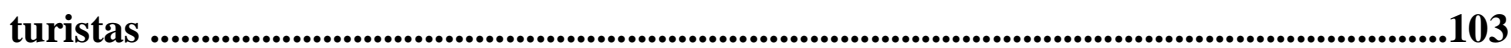

4.1 - As rezadeiras e suas rezas: Como a população de Lavras Novas se apropria de

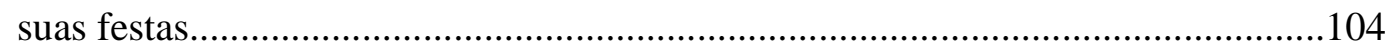

4.1.1 - As diferentes relações do povo com as festas e os festivais. 104

4.1.2 - Queijos, vinhos e Blues: o turismo dos festivais. 109

4.1.3 - Santos e pagãos: o turismo religioso e suas peculiaridades. 117

Considerações finais 127

Referências bibliográficas 132

Anexos 135 


\section{RESUMO}

O presente trabalho trata das relações estabelecidas entre as festas da comunidade de Lavras Novas - MG, o crescimento do turismo na região nos últimos anos e sua relação com os veículos de comunicação de massa.

Analisa, a partir do estudo de duas festas populares subalternas de Lavras Novas MG, como o constante aumento do turismo a partir de 1980, e a exposição da comunidade como pólo turístico pela mídia, podem ter relação com possíveis mudanças ocorridas nas manifestações culturais da localidade, e de que forma estas mudanças atuam dentro da constituição sócio-cultural de Lavras Novas.

O trabalho procura entender o caráter das culturas populares subalternas a partir do método materialista e dialético, dentro do atual contexto sócio-cultural globalizado. Este estudo consiste em não somente destacar e reafirmar os efeitos dos meios de comunicação de massa através de teorias da recepção, nem do turismo como atividade mercadológica alienante, mas também, e primordialmente, analisar sociológica e antropologicamente a forma (direta e indireta) como essas duas variáveis (meios de comunicação e turismo) podem interferir na estrutura tradicional de uma comunidade, incentivando a formação de um processo de transformação das culturas populares subalternas e de suas festas populares. Procura-se, então, a partir disso, traçar perspectivas e possibilidades para o futuro identitário da comunidade de Lavras Novas.

Como objetos de pesquisa deste trabalho tomam-se: as Festas de Nossa Senhora dos Prazeres e do Divino Espírito Santo, e o ritual de Encomendação das Almas, presente nas festividades de Semana Santa, procurando distinguir as diversas formas como as culturas populares subalternas podem ser entendidas, transformadas, significadas ou dessignificadas.

Palavras - Chave: Lavras Novas, festas populares subalternas, identidade cultural, turismo e meios de comunicação de massa. 


\section{INTRODUÇÃO}

Lavras Novas, distrito da cidade de Ouro Preto, Minas Gerais, localizada na região da Zona da Mata Mineira, vem sofrendo um processo de estímulo ao desenvolvimento do turismo regional desde o início dos anos 80 do Século XX. Neste processo, o distrito está re-descobrindo suas potencialidades históricas, culturais e ambientais, que têm sido referenciadas como produtos a serem consumidos.

$\mathrm{O}$ distrito se tornou referência em ecoturismo, turismo cultural e gastronômico na região da Zona da Mata, recebendo uma grande quantidade de turistas vinda de regiões próximas, como Ouro Preto e Belo Horizonte, aos finais de semana. O número de turistas aumenta muito durante os feriados, onde o calendário turístico tem seus pontos altos. Desta forma, a comunidade é palco de manifestações culturais durante o ano todo, as quais atualmente começam a projetar-se no circuito do Turismo Cultural Brasileiro.

Lavras Novas possui um passado colonial escravista que trás para a comunidade um universo cultural muito rico, manifestado na típica culinária mineira, no patrimônio arquitetônico (anterior da criação de Vila Rica - atual Ouro Preto, possuindo uma capela construída no século XVII), na música (que sincretiza ritmos típicos africanos, como a marujada, com temas católicos), e no artesanato feito em bambu, bem como na confecção de colchas, tapetes e adereços em chita e fuxicos.

Como estes valores vêm sendo midiaticamente evidenciados, na motivação para o consumo do turismo cultural, houve na região, um incentivo ao turismo que acabou por fazer com que esta atividade se tornasse, a partir da década de 1990, a principal atividade econômica da comunidade. Com isso, aos poucos, foram chegando as grandes pousadas, se multiplicando as lojas de artesanato, se criando festivais de vinhos, de blues, festivais gastronômicos, empresas de ecoturismo, que nem sempre referenciavam as características identitárias da comunidade.

Os moradores de Lavras Novas, em um primeiro momento, para alcançarem os investimentos necessários para o desenvolvimento local, buscaram ressaltar suas potencialidades e peculiaridades, muitas vezes com a idéia de criar uma nova "imagem" a fim de atender as mais diversas demandas em turismo e aumentar a renda. Porém, enxergar no tratamento do patrimônio material e imaterial uma atividade meramente econômica pode 
gerar sérios problemas para as culturas populares subalternas. A produção cultural de uma comunidade, referenciada em suas necessidades diretas, a partir da presença de um atravessador, por exemplo, interligado ao mercado externo, disposto a comprar o seu produto, acaba direcionando a sua atividade de acordo com os interesses desse elemento externo, e não mais de acordo com suas próprias demandas, podendo afetar tanto a qualidade da produção quanto à definição do que produzir e como produzir.

O mesmo tipo de descaracterização pode ocorrer no âmbito das produções imateriais, que ao serem vistas como fontes de renda pela comunidade, podem passar a se adaptar ao gosto médio dos turistas, perdendo o valor simbólico de pertencimento identitário e se transformando em espetáculos que não possuem valor em relação à cotidianidade.

Considerando a festa popular subalterna como um rico objeto de estudo, esta pesquisa aborda a essência do fenômeno festa, delimitando-se ao universo simbólico das festas populares de Lavras Novas, remetendo, para isso, ao contexto histórico em que o distrito se insere, sua formação sócio-cultural e também às mudanças mais recentes ocorridas em suas manifestações populares.

São analisadas as modificações ocorridas na comunidade após a chegada da luz elétrica, dos veículos de comunicação, e do crescimento abrupto do turismo, visando entender se estas transformações influenciaram ou não na forma de significar da comunidade. Analisa-se também, se o turismo que vêm acontecendo na comunidade, principalmente nos períodos das festas, ocorre, predominantemente, de forma predatória ou emancipadora, elencando os principais indícios para tais conclusões. É importante entender que o caso de Lavras Novas serve para exemplificar um fenômeno que vem ocorrendo a nível global com as culturas populares subalternas. Segundo Ferreira:

“... atualmente, com a expansão do turismo, a nível mundial, um dos assuntos mais explorados como consumo turístico são justamente as festas populares. Não somente na Europa, mas mesmo no Brasil, e em outros países da América Latina, esta opção tem sido uma alternativa para incrementar as economias locais das pequenas cidades marginalizadas pelo processo neoliberal, cuja natureza é privilegiar a produção para exportação, ignorando as economias de pequeno porte." (Ferreira: 2006: 61) 
Em relação às pequenas comunidades, a autora cita ainda a ação repressiva da comunicação midiática e como o processo de globalização propagado pelas mídias podem encabeçar mecanismos de alienação, instigando a padronização de hábitos e o turismo predatório, e assim interferindo diretamente na identidade cultural.

É justamente neste sentido que foram abordados os processos identitários da comunidade de Lavras Novas. Para tal, delimita-se um espaço temporal que vai do início da década de 1970 (com chegada da Luz elétrica ao distrito) até os dias de hoje. Com a chegada da luz elétrica houve um aumento significativo do turismo, que se intensificou a partir de 1980, e também foram chegando, aos poucos, os primeiros veículos de comunicação de massa à região. É importante lembrar também, que na década de 1990 houve um grande aumento nas atividades turísticas a nível global, uma nova moda em turismo. Segundo a Organização Mundial de Turismo (OMT), “o número de turistas no mundo, passou de 150 milhões de viajantes em 1995, para 500 milhões em 2008". ${ }^{1}$ O investimento em turismo aumenta a cada ano, todos os dias são descobertos novos roteiros com a finalidade de atender aos mais diversificados gostos.

No sentido de avaliar as trocas e os possíveis impactos ocorridos na comunidade após a chegada do turismo e da exposição da comunidade nos meios de comunicação de massa como pólo turístico, pesquisou-se sobre as "maiores" festas populares da comunidade: a Festa do Divino Espírito Santo e de Nossa Senhora dos Prazeres (que acontecem concomitantemente) e a de Encomendação das Almas, que acontece na Semana Santa. Nestas festas analisou-se como poderiam existir elementos do que se denomina turismo predatório, e a forma como estes elementos influenciam na interação social cotidiana da comunidade com sua identidade cultural.

Examinaram-se as festas escolhidas para a pesquisa, de forma a distinguir o que foi incorporado naturalmente aos valores tradicionais da comunidade (considerando o caráter dinâmico na construção da cultura) e o que pode ser considerado deformação e descaracterização cultural.

Diante das transformações impostas às culturas subalternas pelo processo de globalização, este trabalho procura discutir a situação em que se encontram as culturas

\footnotetext{
${ }^{1}$ OMT (1995) Disponível em <http//:www.world-turism.org>. Acesso em 25 de maio de 2009.
} 
subalternas, ao serem submetidas a modos hegemônicos de gestão, encadeando a descaracterização dessas enquanto manifestações identitárias.

Por outro lado, é importante não generalizar e não relegar tudo o que possui elementos da cultura de massa, ou que está exposto, direta, ou indiretamente como produto, como descaracterizado culturalmente, pois devem-se entender como diferentes os mecanismos descaracterizadores dos mecanismos de vendagem. Apesar de estes estarem ligados, na maioria das vezes, um não determina o outro.

Assim, foram analisadas também, como se dão as diferentes formas de resistência das culturas populares, atuando de maneira a buscar por um turismo emancipador, e como convivem, na sociedade de Lavras Novas, características do turismo predatório e do turismo emancipador, procurando distinguir elementos de transição e os rumos para os quais caminham o futuro cultural da comunidade.

Partindo do princípio de que conhecer é transformar, este trabalho optou utilizar o método dialético como o principal caminho para a produção de conhecimento, neste sentido a fundamentação teórica sustentar-se-á sobre elementos de elevação do abstrato ao concreto dentro do conceito de totalidade. Utilizará também, o método histórico e o método lógico, pois estes dois métodos acham-se no caminho ascendente do pensamento abstrato ao concreto e do simples ao complexo, que se correspondem com o processo histórico real. ${ }^{2}$

A relação sujeito $\mathrm{X}$ objeto, tratada de forma dialética, propiciou momentos em que o sujeito (pesquisador), ancorado em bases teóricas, cedeu lugar para seguir rumos apontados pelo objeto. A partir destas bases metodológicas se tornou possível procurar de forma mais precisa, entender as relações entre os veículos de comunicação de massa, o turismo e as festas populares de Lavras Novas.

A articulação envolvendo culturas populares subalternas e consumo é demasiado complexa. Não obstante, os exemplos mostrados não deixam dúvidas quanto à necessidade de instaurar eixos de investigação complementares e interdependentes que enfoquem esta temática. É necessário sair do terreno da especulação para produzir pesquisas que possam ajudar a esclarecer a relação, ainda um pouco obscura entre a cultura popular subalterna, as grandes mídias e o turismo. É necessário ater-se às manifestações das culturas populares

\footnotetext{
${ }^{2}$ Ferreira, M. N. Alternativas Metodológicas para a produção científica. São Paulo. Celacc/ Eca/ USP. 2006. p 115.
} 
subalternas, consideradas de resistência, não como únicas esperanças, mas sim perceber o que foi descaracterizado, o que foi vendido, e de que forma isso ocorreu para se tornar possível modificar a realidade.

Não basta continuar afirmando que o mercado e a indústria cultural deslocam os sentidos das manifestações culturais subalternas, que as colocam como produtos a serem consumidos e descartados (não desconsiderando tal afirmação), mas é necessário produzir estudos que demonstrem a forma como acontecem essas apropriações pela indústria cultural.

É necessário estudar a cultura popular subalterna e suas transformações nos mais diversos âmbitos. No caso deste trabalho de pesquisa espera-se instigar novas investigações sobre festas, consideradas com um rico objeto comunicacional de estudo.

Neste sentido existem, antes de abordar o terreno das festas e das manifestações culturais da comunidade, muitos aspectos a serem ressaltados sobre o distrito de Lavras Novas, como sua formação histórica e sócio-cultural. Assim, se torna importante conhecer as características gerais de cada festividade, suas origens e sua relação com o contexto histórico. Neste trabalho, foi feito um apanhado teórico sobre os conceitos abordados, além de um levantamento histórico sobre a comunidade, sua origem e suas tradições.

Partindo sempre do pressuposto de que o contexto histórico e social é inseparável do objeto, que tal contexto molda o objeto assim como objeto o molda incessantemente, de forma dialética, estudar o caso de Lavras Novas faz tornar mais palpável, também, os vários estudos teóricos realizados sobre o fenômeno festa, os ritos que sobrevivem ao tempo e sua relação com a comunicação na era da globalização.

Desta maneira, para entender de forma mais dinâmica a relação dialética entre as culturas populares, suas festas e a sociedade, tem-se como fundamentos para esta pesquisa a dinamicidade intrínseca as culturas populares subalternas e sua relação com a historicidade dos fatos, estando embutidos nos capítulos deste trabalho, apresentados a seguir:

No primeiro capítulo - LAVRAS NOVAS: DAS MINAS DE OURO AOS FESTIVAIS DE VINHO - são apresentadas as origens da comunidade de Lavras Novas, como a região começou a ser povoada, a forma como chegaram até lá os primeiros habitantes para a exploração das minas de ouro, bem como quem eram e de onde eram 
provenientes. Dentro desta temática estão apontados os principais elementos étnicos formadores do distrito, onde o elemento negro tomará posição de destaque devido ao legado cultural deixado à região, presente na cotidianidade e em todos os tipos de manifestações populares. Aponta-se também, cronologicamente, as mudanças na forma de ocupação do espaço de Lavras Novas e no modo de produção da vida material da comunidade a partir das variáveis: luz elétrica, mídia e turismo.

O segundo capítulo - IDENTIDADE CULTURAL, MídIA E TURISMO: AS FESTAS POPULARES SUBALTERNAS ENTRE A RESISTÊNCIA E A REIFICAÇÃO - apresenta todo o problema proposto no projeto de forma a explicitar questões intrínsecas ao objeto de estudo: festas populares subalternas. Neste capítulo estão concatenados todos os elementos presentes nas considerações teóricas em se embasa este trabalho, de forma a interligar conceitos como subalterno e hegemônico às formas de reificação da cultura popular através da lógica da indústria do turismo em parceria com a mídia. E, ao mesmo tempo, demonstrar a cultura popular subalterna com um locus de resistência, por isso um ambiente que envolve constantes conflitos.

O terceiro capítulo - AS FESTAS POPULARES DE LAVRAS NOVAS: ENTRE

OS SANTOS E AS ALMAS - explica as relações entre as raízes das festas no Brasil com a religiosidade, posteriormente se atendo apenas às festas propostas para estudo por este trabalho: a Festa do Divino Espírito Santo e de Nossa Senhora dos Prazeres (que acontecem em uma mesma data comemorativa) e o ritual de Encomendação das Almas, presente nas festividades de Semana Santa. Estão elencados os elementos católicos e os elementos negros presentes em cada festividade, a fim de apontar o caráter sincrético destas festividades, bem como a evolução temporal na maneira de sua organização no distrito de Lavras Novas. Neste capítulo são feitas descrições das festas em sua forma de organização, bem como durante sua execução.

No quarto capítulo - AS FESTAS POPULARES E SUAS INTER-RELAÇÕES: A PESQUISA, A COMUNIDAdE E OS TURISTAS - apresentam-se os resultados metodológicos da pesquisa de campo, apontando as diferenças entre o que foi ressignificado, des-significado, deformado, descartado ou transformado (considerando o caráter dinâmico das culturas populares) nas festas da comunidade de Lavras Novas, a forma como isso já aconteceu, como acontece hoje e seus principais fatores influenciadores. 
Além disso, expõe-se a forma como o turismo é tratado pela comunidade, principalmente no período das manifestações populares e quais as influências da mídia (diretas e indiretas) nas festas objeto de estudo, bem como na comunidade em sua cotidianidade. 


\section{CAPÍTULO I: \\ DAS MINAS DE OURO AOS FESTIVAIS DE VINHO}

\section{1 - A formação do distrito de Lavras Novas:}

Lavras Novas, atualmente, é um dos treze distritos de Ouro Preto (São eles: Amarantina, Antônio Pereira, Cachoeira do Campo, Engenheiro Correia, Glaura, Lavras Novas, Miguel Burnier, Santa Rita, Santo Antônio do Leite, Santo Antônio do Salto, São Bartolomeu e Rodrigo Silva), situa-se a $13 \mathrm{~km}$ da cidade, e a $120 \mathrm{~km}$ de Belo Horizonte. Está localizada no alto da Serra do Espinhaço (com altitude entre 1.200 e 1.300 metros) ao sul da cidade de Ouro Preto, e possui cerca de $50 \mathrm{~km}$ de extensão territorial. A região se encontra em uma área de transição entre a Floresta Atlântica e o cerrado, predominando a vegetação arbustiva. O distrito possui população de aproximadamente 1500 habitantes, de maioria negra (cerca de $90 \%){ }^{3}$

Entretanto, para melhor compreender este universo é necessário, primeiramente, retomar a formação histórica do local, e relacionar alguns documentos antigos em que o nome da comunidade é descrito. É importante lembrar que os documentos que comprovam a existência do povoado, e em quais podemos conhecer um pouco mais sobre sua formação, são externos a comunidade, ou seja, não produzidos pela população local.

A história do distrito de Lavras Novas se confunde com a própria história de Minas Gerais, e começa com a corrida pelo ouro no Brasil colonial. O desbravamento da região de Minas iniciou no século XVII, com a descoberta de ouro por bandeirantes paulistas que, a princípio, procuravam ouro e pedras preciosas na região da Capitania do Espírito Santo. A primeira região onde o minério foi encontrado foi na Serra de Sabarabuçu, nos Ribeirões do Carmo e do Tripuí, em 1693.

"Por volta do fim do século XVII, as descobertas de ouro coincidiram com a violenta queda nos preços do açucar, cuja exploração havia há muito se desenvolvido nas Antilhas inglesas, francesas e holandesas. Simonsen concluiu então que, pela fascinação do ouro e instigados ainda pela depressão econômica das zonas açucareiras, operou-se um pronunciado movimento emigratório das regiões dos engenhos e outros pontos do

\footnotetext{
${ }^{3}$ Prefeitura de Ouro Preto. Plano de inventário do acervo cultural de Ouro Preto: Secretaria Municipal de Cultura: 2005.
} 
Brasil, assim como grande número novos elementos portugueses para as terras da mineração.” (MUKUNA, 2006: 63)

Com a crescente exploração de ouro e pedras preciosas foram se desenvolvendo os arraiais. Ainda em 1693 foi fundado o arraial de Nossa Senhora do Ribeirão do Carmo, que em 1711 foi elevada à primeira vila de Minas Gerais, que corresponde ao núcleo original da cidade de Mariana. $^{4}$

No período de formação do arraial de Nossa Senhora do Ribeirão do Carmo já havia se desenvolvido vários outros arraiais nas proximidades das minas, acredita-se datar deste período o começo da exploração de ouro no que se chama de atual distrito de Lavras Novas, porém não existem provas documentais que apontem para uma data precisa do início da exploração do ouro na região. Acredita-se que a exploração no distrito iniciou-se ainda no final do século XVII, devido a documentos históricos que comprovam esta região já estar desenvolvida nos anos de $1711^{5}$ e $1717 .^{6}$

Segundo Antonil ${ }^{7}$, em seu livro Cultura e opulência do Brasil por suas Drogas e Minas $^{8}$, a região das Minas Gerais estava super lotada já em 1697, e os preços já se encontravam inflacionados.

Devido a grande quantidade de ouro encontrada na região das Minas Gerais, foram gerados vários conflitos pelo seu direito de exploração, como a Guerra dos Emboabas que aconteceu entre 1707 e 1709. Em decorrência da grande exploração do ouro, Minas Gerais teve um povoamento muito rápido, sendo criada em 1709, a Capitania de São Paulo e Minas de Ouro, desmembrada da Capitania do Espírito Santo. Em resposta a Guerra dos

\footnotetext{
${ }^{4}$ TÁRCIA. C. Jornal Santo de Casa. Ouro Preto: 2003, n.45.

${ }^{5}$ Este documento se trata de uma Carta de Sesmaria, escrita pelo General Afonso de Albuquerque, em que o nome de Lavras Novas é citado para descrever caminhos da região. Este documento encontra-se presente no Arquivo da Casa Setecentista de Marina.

6. Este documento cita uma grande festa organizada no arraial de Lavras Novas para o batizado de Maria dos Prazeres, filha de Isabel Rodrigues e do sertanista Baltazar de Godoy. No documento cita-se a mina "Lavras Novas do Coronel Furtado", descoberta por membros da família Cubas de Mendonça (família de portugueses bandeirantes paulistas). Este documento encontra-se presente no Arquivo da Casa Setecentista de Marina.

${ }^{7}$ João Antônio Andreoni, que adotou o nome de André João Antonil nasceu e, 1649 na região da Toscana, na Itália, se formou em direito civil pela Universidade de Perúgia . Ingressou na Companhia de Jesus em 1667. Em 1681 veio para o Brasil convidado pelo padre Antônio Vieira, estabelecendo-se em Salvador. Em 1711, publicou a obra Cultura e Opulência do Brasil por suas Drogas e Minas, descrevendo com riqueza de detalhes a vida social e econômica no Brasil colônia.

${ }^{8}$ ANTONIL. A. J. Cultura e opulência do Brasil por suas drogas e minas. Belo Horizonte: Itatiaia; São Paulo: Edusp, 1982.
} 
Emboabas, no ano de 1720, a Capitania de Minas Gerais foi separada da Capitania de São Paulo, tendo como capital Vila Rica (atual Ouro Preto). ${ }^{9}$

A região do atual distrito de Lavras Novas, no final do século XVII e início do XVIII, estava inserida no que era chamado de distrito do Itatiaia. Através de registros de terras é possível saber qual o tamanho aproximado do antigo distrito: abrangia o que são hoje os distritos de Lavras Novas, Santo Antônio do Salto, Santa Rita, Santana da Chapada e Itatiaia, além disso, parte da Serra do Deus te Livre (atual Serra de Ouro Branco). Para a Coroa, Itatiaia era um grande distrito subdividido em dois distritos menores: Lavras Novas e Santa Rita. Já para a Igreja a região era conhecida como freguesia divida em Aplicação da Capela de Santa Rita e Aplicação da Capela de Nossa Senhora dos Prazeres de Lavras Novas. ${ }^{10}$

Há uma passagem no livro de Antonil que cita a existência de ouro na região de Itatiaia no início do século XVIII: "Não falo da mina da serra de Itatiaia (a saber, do ouro branco, que é ouro ainda não bem formado), distante do ribeiro do Ouro Preto oito dias de caminho moderado até o jantar...”. (ANTONIL, 1982: 75).

O governador e fundador de Vila Rica, Capitão General Afonso de Albuquerque foi o redator do primeiro documento civil em que consta o nome de Lavras Novas. Trata-se de uma Carta de Sesmaria que data do início do século XVIII, $1711^{11}$. Tal documento cita Lavras Novas para descrever os caminhos e estradas da região. Com base neste documento, pode-se, novamente, presumir que a região foi povoada muito antes disso.

Depois deste, o próximo documento em que o nome de Lavras Novas é citado data de 1717, e trata-se do registro de batismo de duas meninas: Thereza (não consta o sobrenome) e Maria dos Prazeres. No documento não consta também o local exato do batizado, consta apenas que aconteceu no arraial de Lavras Novas, mas não se sabe se em alguma capela, ermida ou oratório. ${ }^{12}$

Em outubro de 1725, existe uma certidão de batismo que comprova a existência da Capela de Nossa Senhora dos Prazeres de Lavras Novas. Nesta data o padre Antônio Moutinho batizou Anna, filha de Paschoal Ferreira da Costa e Josepha Cubas de Mendonça

\footnotetext{
${ }^{9}$ TÁRCIA. C. Jornal Santo de Casa. Ouro Preto: 2003, n.45.

${ }^{10}$ TÀrCIA. C. Jornal Santo de Casa. Ouro Preto: 1998, n. 2.

${ }^{11}$ TÀRCIA. C. Jornal Santo de Casa. Ouro Preto: 2003, n.44.

12 TÀRCIA. C. Jornal Santo de Casa. Ouro Preto: 2003, n.45.
} 
(família tradicional da região) na Igreja de Nossa Senhora dos Prazeres. ${ }^{13}$ Antes desta data não existem documentos que comprovem sua existência, nem que falem sobre início e término de sua construção. Também não há nenhum documento em que conste a forma como a Igreja de Nossa Senhora dos Prazeres de Lavras Novas foi construída. Muitos moradores do distrito afirmam que a igreja foi construída pelos escravos, que apanhavam e levavam pedras até a construção. Esta versão seria a mais condizente com a realidade social do distrito, porém não existem comprovações documentais para que se possa afirmar isso com exatidão.

Uma das principais razões para a falta de documentos históricos que falem sobre a formação da comunidade deve-se, principalmente, a não existência de uma sede urbana maior aos arredores do povoado no início do século XVIII, e também da não existência de arquidioceses nas regiões próximas (É importante lembrar que o distrito de Lavras Novas é anterior a formação de Vila Rica - atual Ouro Preto), visto que muitos dos documentos, antigamente, eram guardados nas igrejas. "Devido a essa prática, com a falta de cuidado no armazenamento desses documentos, muitos deles se perderam", afirma o historiador da prefeitura de Ouro Preto, João Paulo Martins ${ }^{14}$.

Por volta de 1740, a região de Lavras Novas já estava bem mais desenvolvida. Isso se deu principalmente devido à grande quantidade de escravos que foi trabalhar nas minas de ouro próximas à região. As minas e as terras baratas atraíram muitas famílias de fazendeiros e mineradores.

No entanto a mineração começou a diminuir por volta de 1750 em toda Minas Gerais, o que levou a Coroa Portuguesa a tentar não diminuir os lucros através do aumento da arrecadação de impostos, o que culminou na Inconfidência Mineira em 1789. Mesmo com a decadência da mineração se tornava difícil estabelecer outro tipo de atividade econômica em Minas Gerais devido ao grande isolamento e controle rígido exercido pela Coroa, sendo que a forma de agricultura predominante era a de subsistência.

A mineração sobreviveu até o final do século XVIII, pois os mineradores deixaram a região por ser um local de difícil acesso e que, por mais que ainda existisse exploração de ouro, mesmo que decadente, esta já não compensava o custo dos transportes e da chegada

\footnotetext{
${ }^{13}$ TÀRCIA. C. Jornal Santo de Casa. Ouro Preto: 2003, n.45.

${ }^{14}$ Fonte: trabalho de campo realizado em 16 de outubro de 2009.
} 
de suprimentos à região. A maioria dos fazendeiros, com a decadência das minas, da atividade comercial e a falta de mão-de-obra, também abandonou suas terras ${ }^{15}$.

Relacionados às histórias referentes à mineração, à formação basicamente negra do distrito e à influência católica, surgiram as lendas, os mitos e os causos que povoam o imaginário popular da comunidade há cerca de trezentos anos.

Uma das principais lendas relacionadas a Lavras Novas é a de que o distrito teria sido formado por escravos fugidos. A maioria dos moradores, principalmente os mais velhos, assegura esta história. Mesmo em alguns sites de turismo na internet podemos encontrar tais informações.

Entretanto, segundo a jornalista Christina Tárcia ${ }^{16}$, que se dedica a pesquisar sobre o tema, para realização de reportagens veiculadas no jornal Santo de Casa, existem comprovações documentais que demonstram o contrário. De acordo com a jornalista, existem provas de que Lavras Novas não é remanescente de quilombo ${ }^{17}$, ou seja, não é formada por escravos fugidos, dentre estas provas a jornalista cita:

- O fato de que o distrito era área de mineração catalogada pelo governo, e na documentação da época constam os tributos pagos pelos moradores de Lavras à coroa.

- Lavras Novas é citada em documentos, tais como carta de sesmaria. Isto não aconteceria se a população tivesse sido formada por escravos fugidos. ${ }^{18}$

Para ela, a lenda de que a comunidade seria remanescente de quilombo pode ter sido gerada devido à forma de organização social em que se encontrava a comunidade no início do século XX. Não havia preocupação com a propriedade de terra; era consenso de que ela pertencia à santa padroeira da cidade, Nossa Senhora dos Prazeres; e a maioria dos habitantes possuía laços consangüíneos. Além disso, as festas que ocorriam na comunidade eram praticamente fechadas, havia uma organização coletiva e a presença de muitos elementos típicos da cultura africana. ${ }^{19}$

\footnotetext{
${ }^{15}$ TÀRCIA. C. Jornal Santo de Casa. Ouro Preto: 2003, n.43.

${ }^{16}$ Christina Tárcia é a jornalista responsável pelo Jornal Vila Rica, e produtora do Jornal Santo de Casa, o qual procura explicar a formação histórica dos distritos de Ouro Preto, baseada em pesquisas documentais feitas pela jornalista.

${ }^{17}$ A jornalista Christina Tárcia, em sua pesquisa, considera como quilombola somente comunidades formadas por negros fugidos.

${ }^{18}$ TÀRCIA. C. Jornal Santo de Casa. Ouro Preto: 2003, n.43.

${ }^{19}$ TÀRCIA. C. Jornal Santo de Casa. Ouro Preto: 2003, n.43.
} 
No final do século XX, mais precisamente na década de 70, Lavras Novas se depara com profundas mudanças. Isso se deve, primeiramente, à chegada da Fazenda do Manso, com sua cultura de chá à região. A década de 1970 também destaca diversas alterações significativas na sociedade local, com a chegada da luz elétrica na comunidade. A partir de 1980 o turismo começa a crescer, se tornando a principal atividade do distrito na década de 1990.

\section{2 - A formação étnica do distrito de Lavras Novas: Entre negros,} portugueses e índios carijós.

Para explicar a formação étnica da sociedade de Lavras Novas é necessário, novamente, remeter-se a formação histórica de Minas Gerais, no final do século XVII, com a chegada dos primeiros bandeirantes.

Com a descoberta de ouro nas regiões da Serra de Sabarabuçu, nos Ribeirões do Carmo (região da atual cidade de Mariana) e do Tripuí, em 1693, os bandeirantes, vindos principalmente de São Paulo, capturaram vários índios nativos da região para trabalhar como escravos na mineração, pois estes representavam a única opção de mão de obra escrava nas minas no final do século XVII. A mão de obra indígena foi utilizada em toda região, inclusive lutaram ao lado dos bandeirantes na Guerra dos Emboabas. Os nativos da terra eram conhecidos como índios carijós, pertencentes à Nação Guarani, e eram grandes conhecedores das propriedades curativas das plantas. ${ }^{20}$

Os índios carijós foram muito usados no início da colonização da região de Minas Gerais, eram 34.475 escravos $^{21}$ em 1718, mas foram rapidamente substituídos pela mão-deobra africana. ${ }^{22}$

Essa rapidez dos bandeirantes (em sua maioria descendentes de portugueses vindos de São Paulo) na substituição do índio pelo africano se deu por vários motivos: os índios da

\footnotetext{
${ }^{20}$ VENANCIO, R. P. Os Últimos Carijós: Escravidão Indígena em Minas Gerais: 1711-1725. Revista Brasileira de História, São Paulo, v. 17, n. 34, 1997.

${ }^{21}$ Estão inclusos nestes números apenas escravos que trabalhavam nas minas auríferas, não estando inclusos os que trabalhavam na agricultura de subsistência ou como criados.

${ }^{22}$ É possível saber o exato número de escravos indígenas e negros na região das minas em algumas datas devido à conservação de algumas listagens de capitação - imposto que incidia sobre a propriedade escrava. Algumas das listagens de Capitação podem ser encontradas na Casa do Contos, em Ouro Preto; outras no arquivo da Paróquia de Antônio Dias.
} 
terra apresentavam baixas taxas de natalidade; havia uma alta taxa de mortalidade devido a baixa resistência às doenças do branco, houve várias fugas, e com o enriquecimento da região do ouro se tornou possível a compra de negros africanos. ${ }^{23}$

Em Lavras Novas não foi diferente, a escravidão de índios foi intensa no início do século XVIII, época em que constituíam a principal mão-de-obra para a mineração local. Em documentos da época são comuns citações sobre a presença de ameríndios como escravos, como por exemplo em registros de batismo, casamento e sepultamento, em cadernos de notas e em tabelas de preços de escravos. No documento de registro de batismo de Maria dos Prazeres, de 1717, em Lavras Novas, consta a designação da etnia de sua mãe:

"Aos vinte e cinco dias do mês de dezembro de mil setecentos e dezessete anos, batizou e pôs os Santos Óleos da minha licença o padre Frei Conrrado do Desterro a Maria, filha de Balthazar Pinto de Godois, e de Izabel, mulher forra da nação carijó. Foram padrinhos Miguel Dias de Souza, e Maria do Nascimento, mulata forra, e de que fiz este assento era et supra." 24

A grande quantidade de citações encontradas sobre a existência de índios carijós nos poucos documentos que ajudam a entender um pouco mais sobre a formação da comunidade de Lavras Novas, comprova que o indígena esteve presente em grande quantidade na região.

Porém, é necessário ressaltar, que a maioria dos documentos referentes à presença de índios carijós em Lavras Novas são documentos que apontam estes índios como escravos domésticos, o mais antigo deles data de $1717^{25}$, período em que a escravidão dos índios nas lavras auríferas já havia diminuído. Nos trabalhos domésticos os homens trabalhavam na caça, na pesca, coleta e transporte de mercadorias pelas trilhas da região; já as mulheres nas lavouras de subsistência, no artesanato e em serviços domésticos em geral.

De acordo com o observado nos registros de batismo, certidões de casamento e de sepultamento, pode-se perceber a grande miscigenação entre os três elementos fundadores

\footnotetext{
${ }^{23}$ VENANCIO, R. P. Os Últimos Carijós: Escravidão Indígena em Minas Gerais: 1711-1725. Revista Brasileira de História, São Paulo, v. 17, n. 34, 1997.

${ }^{24}$ Este documento é o mais antigo em que consta a designação da etnia carijó na comunidade de Lavras Novas. O documento encontra-se presentes no Arquivo da Casa Setecentista de Marina.

${ }^{25}$ Conforme nota 22.
} 
do distrito. Na certidão de batismo de Maria dos Prazeres, de $1717^{26}$, citada anteriormente, mostra-se a miscigenação entre descendente de família portuguesa com uma índia carijó. É comum encontrar em certidões de casamento a designação da etnia dos noivos quando um deles não era de descendência portuguesa, o que facilitou confirmar a grande miscigenação na região de Lavras Novas. ${ }^{27}$

Com a diminuição crescente do contingente indígena na exploração do ouro devido aos diversos motivos já apresentados, e com o crescimento econômico abrupto da região das minas, se tornou possível financiar o tráfico negreiro também para esta região (como já acontecia nas regiões litorâneas brasileiras), então foram trazidos os negros africanos para serem escravizados na mineração.

Os principais grupos negros que entraram em Minas Gerais, através do tráfico negreiro, foram os Bantos e os Sudaneses (assim como em todo o território brasileiro), logo no início do século XVII.

Os negros bantos, originários do sul da África (Angola, Congo, Moçambique), foram trazidos, primeiramente, para as regiões do Maranhão, Pernambuco e Rio de Janeiro, onde, em migrações menores, foram levados para São Paulo e Minas Gerais. Já os sudaneses vieram da África ocidental, da região do Rio Níger. Entre os grupos sudaneses destacam-se os nagôs (iorubás), os jêjes, os mina, os haussás. Os bantos e os sudaneses não foram os únicos grupos serem trazidos para o Brasil e para Minas Gerais, porém foram os grupos com contingente mais significativo. ${ }^{28}$

Muitos pesquisadores afirmam hoje, quase que consensualmente, que os sudaneses eram preferencialmente levados para Minas Gerais, pois estes já tinham conhecimento técnico do trabalho com metais em suas nações de origem (principalmente um subgrupo conhecido como Mina). Por outro lado sabe-se que os bantos também entraram em grande quantidade na região, e que sua influência foi muito grande, apesar de serem considerados, na época, menos inteligentes e desenvolvidos que os sudaneses.

Apesar da preferência dos bandeirantes pela mão de obra sudanesa ao longo do período de mineração abundante, principalmente no início do século XVIII, os legados de ambos os grupos influenciaram muito a região das Minas Gerais e, decorrentemente, a

\footnotetext{
${ }^{26}$ Este documento encontra-se presente no Arquivo da Casa Setecentista de Marina.

${ }^{27}$ TÁRCIA. C. Jornal Santo de Casa. Ouro Preto: 2003, n.45.

${ }^{28}$ MUKUNA, K. Contribuição banto na música popular brasileira. São Paulo: Global, 1980.
} 
região de Lavras Novas (conhecida como distrito do Itatiaia, como afirmado anteriormente). $\mathrm{Na}$ tabela seguinte pode-se observar o equilíbrio entre os 2 grupos na região do Itatiaia (onde se localizava o atual distrito de Lavras Novas) no auge da mineração. $^{29}$

\section{REPARTIÇÃO DOS ESCRAVOS AFRICANOS SEGUNDO A ORIGEM (Localidades selecionadas - 1718) $^{30}$}

$\begin{array}{lcccc}\text { Grandes Grupos e "Nações" } & \text { Pitangui } & \text { Itatiaia } & \text { São João d'El Rei } & \text { Total } \\ \text { Total de Sudaneses } & 107 & 201 & 82 & 390 \\ \text { Total de Bantos } & 133 & 202 & 186 & 521 \\ \text { Total Geral } & 240 & 403 & 268 & 911\end{array}$

$\mathrm{Na}$ maior parte do período da mineração ativa houve um equilíbrio entre a quantidade de bantos e sudaneses na região de Lavras Novas (pertencente a Itatiaia), porém os preços inferiores dos bantos os tornaram uma opção em relação ao sudanês, mais caro. Com isso, no final do período da mineração, com as minas já decadentes, pode-se perceber uma quantidade muito maior de bantos do que sudaneses. De acordo com o que afirmam Luna e Costa:

"Os Sudaneses, ainda que preferidos pelos mineradores, passaram a entrar segundo taxas decrescentes. Possivelmente os Bantos, vendidos a preços inferiores, apareciam no mercado de escravos como elemento substitutivo face aos Sudaneses. Este fenômeno acarretou o "envelhecimento" da massa de cativos sudaneses, o que implicou o desproporcionado peso relativo de ambos os grupos no conjunto dos vivos, por um lado, e entre os mortos, por outro. Assim, em 1804, os escravos distribuíam-se em Bantos e

\footnotetext{
${ }^{29}$ LUNA, F. V. \& COSTA, I. N. A Presença do Elemento Sudanês nas Minas Gerais. Suplemento Cultural do Jornal O Estado de São Paulo, São Paulo, ano II, no. 188, 26/11/1978, p. 14-16.

${ }^{30}$ Conforme nota 27.
} 
Sudaneses, de acordo com os pesos $84,7 \%$ e $15,3 \%$, respectivamente." (LUNA e COSTA, 1978: 14).

Com a diminuição da atividade mineradora em 1750, e sua profunda decadência no final do século XVIII, o número de escravos reduziu drasticamente. A decadência do ouro levou ao esvaziamento das vilas mineradoras, com o deslocamento das famílias para outras regiões, o que expandiu as fronteiras da capitania de Minas Gerais.

De acordo com Mukuna "... numerosos escravos preferiram permanecer nas proximidades das minas abandonadas, principalmente em algumas regiões de Minas Gerais..." (MUKUNA, 2006: 68), foi o que aconteceu em Lavras Novas. Eram em sua maioria negros alforriados, que passaram a sobreviver, basicamente, da agricultura de subsistência e do artesanato, vivendo praticamente isolados.

\section{3 - O legado cultural: A marujada que é tocada por quem fabrica balaios.}

Em Lavras Novas, assim como em toda região mineradora de Minas Gerais, a influência de portugueses, índios, e negros se faz presente de maneira muito marcante. A influência dos portugueses, trazida pelos bandeirantes, está presente na forte tradição católica da comunidade.

Dentre as principais famílias de bandeirantes que se estabeleceram na região de Lavras Novas (nesta época ainda incluída no que era o distrito de Itatiaia) estão os Cubas de Mendonça, os Penteado e os Leme, dos quais existem vários registros referentes à época da mineração. ${ }^{31}$

A herança religiosa deixada pelos portugueses na região de Lavras é muito forte, tanto que quase todas as festas organizadas pela comunidade (não considerando os festivais organizados pela iniciativa privada) são de caráter religioso, como a Festa do Divino Espírito Santo e de Nossa Senhora dos Prazeres, a Semana Santa, Corpus Chisthi, Coroação de Nossa Senhora, entre outras.

A santa padroeira de Lavras Novas é Nossa Senhora dos Prazeres, da qual a capela local leva o nome. Não se sabe ao certo o motivo de ter-se escolhido esta santa como

\footnotetext{
${ }^{31}$ TÀRCIA. C. Jornal Santo de Casa. Ouro Preto: 2003, n.51.
} 
padroeira, os moradores afirmam que é devido a aparições da Santa no local. Pode-se afirmar que a comunidade é devota de Nossa Senhora dos Prazeres desde 1725, quando já existem documentos que comprovam a existência da igreja da comunidade, dedicada a ela.. De acordo o inventário do acervo cultural da Prefeitura de Ouro Preto, cerca de $90 \%$ da população local é católica. ${ }^{32}$

A influência indígena, apesar de pouco conhecida, existe. Os cestos, balaios, e demais objetos produzidos em bambu podem ser considerados uma herança indígena. Conforme relatos dos moradores do distrito, a fabricação de balaios era uma das principais formas de renda da população até o começo do século XIX, porém uma queimada destruiu os bambuais, dificultando o artesanato em bambu. Mesmo assim o artesanato continua sendo uma atividade muito praticada em Lavras Novas. Seu Carlos Aurélio de Carvalho ${ }^{33}$ é o chefe de uma cooperativa que fabrica objetos de bambu, os forros fabricados por eles são exportados para várias regiões do país através da venda para a Tok e Stok.

Segundo Seu Carlos, a cooperativa existe há mais de vinte anos e foi uma ótima alternativa para ele, pois assim não precisou sair de Lavras Novas para trabalhar em Ouro Preto, como faziam muitos dos moradores da comunidade. Seu Carlos diz que aprendeu a trabalhar com o bambu com seus pais, seus pais aprenderam com seus avós, seus avós com seus bisavós e assim por diante. ${ }^{34}$

Acredita-se serem estas influências advindas dos índios carijós, pois estes possuíam conhecimento de como trabalhar com bambu e muitos deles faziam estes trabalhos nas casas onde executavam serviços domésticos.

Outro costume provavelmente herdado dos índios é o conhecimento de plantas e raízes e suas propriedades curativas, utilizadas desde o preparo de alimentos no dia-a-dia até o preparo de chás específicos. A maioria das mulheres da comunidade possui suas próprias hortas, tanto com hortaliças como com ervas utilizadas no preparo de chás e infusões. Ao conversar com D. Efigênia Vieira Viana, de 69 anos, ela conta que:

"Nós tudo, nós tudo fazia chá. Nós não tomávamos remédio não, era só chá mesmo. Chá caseiro. (...) Eu aprendi com a minha mãe que aprendeu com a

\footnotetext{
$32{ }^{32}$ Prefeitura de Ouro Preto. Plano de inventário do acervo cultural de Ouro Preto: Secretaria Municipal de Cultura: 2005.

${ }^{33}$ Carlos Aurélio de Carvalho possui 66 anos, e é natural de Lavras Novas.

${ }^{34}$ Fonte: trabalho de campo realizado dia 4 de maio de 2010.
} 
mãe dela, ela me ensinou, aí eu faço. (...) Aqui muita gente tem sua hortinha, eu tenho a minha. Eu faço muito chá pra mim, faço pros outros. Oh! Eu faço chá de trançagem, folha de algodão e picão. O que é bom pra tirar a dor e o picão e bom pra anemia, e a folha de algodão tira qualquer inflamação do seu corpo. Gosto muito de tomar chá. Eu faço chá pra mim e faço pros outros." 35

Apesar de poder considerar o conhecimento das plantas como herança indígena, em Lavras Novas estes conhecimentos podem ter se intercambiado com conhecimentos trazidos pelos negros, pois na cultura de alguns povos africanos é comum se tratarem doenças com remédios naturais, como em algumas comunidades banto, por exemplo.

Apesar da presença de muitos elementos vindos do branco (do qual o mais importante pode-se considerar a religião) e de elementos indígenas no distrito de Lavras Novas, a influência do negro pode ser considerada a mais marcante. Ela está presente na culinária, nas músicas, no artesanato, na vestimenta, no jeito de falar e de conviver da comunidade.

Como já foi explanado anteriormente, o distrito de Lavras Novas recebeu muitos negros para trabalharem na mineração, principalmente do grupo banto e sudanês. Todavia, a presença do negro não se encontra somente em uma história distante do distrito, mas sim, está presente na memória dos moradores da comunidade:

"Aqui foi formado por escravos sim, eles vinham tirar ouro, e se não trabalhasse era coro em cima. Eu não vi isso, mas os mais velhos contavam pra nós. Meu avô retirava ouro, assim como o de muita gente aqui. No final acaba que nós somos todos filho destes escravos que trabalhavam aqui! É, somos sim. Desde pequeno a gente escuta falar." 36

Segundo MUKUNA (2006):

"A presença de africanos e seus descendentes durante quase cinco séculos no cenário brasileiro deixou valiosos elementos culturais do velho mundo cujas marcas persistem em várias facetas da expressão artística. Na música, esses elementos, juntamente com o das fontes indígenas e européias forneceram um solo fértil para o crescimento de várias formas (religiosas e

\footnotetext{
${ }^{35}$ Fonte: trabalho de campo realizado em 5 de maio de 2010.

${ }^{36}$ Fonte: trabalho de campo realizado em 5 de maio de 2010
} 
profanas) que serviram, nas décadas passadas como tópico para inúmeros estudos, tanto de musicólogos como de folcloristas." (MUKUNA, 2006: 77)

$\mathrm{O}$ autor afirma ainda que pouca coisa pode ser reivindicada como sendo de uma ou outra origem, dentro dos povos negros que vieram para o Brasil (principalmente entre bantos e sudaneses):

"... devido à considerável quantidade de semelhanças existentes na conceituação básica de culturas entre grupos étnicos africanos, nações, etc. Às vezes o que se acredita ser particularidade de uma dada tribo é também lugar comum em outra tribo, às vezes, de uma família étnica diferente." (MUKUNA, 2006: 78).

Apesar da dificuldade em determinar a origem exata das manifestações de origem africana, podemos afirmar que sua presença é marcante em Lavras Novas e que muitas são suas variações, se apresentando, na maioria das vezes, de forma sincrética ao catolicismo, religião predominante na comunidade. O congado, por exemplo, se encontra vivo na comunidade, se manifestando nas cerimônias religiosas e festivas.

Os congados começaram no Brasil com os desfiles ocorridos nas festas organizadas pelas irmandades de escravos por ocasião da coroação simbólica de Reis e Rainhas africanos ou afro-descendentes. A Congada, assim como o Moçambique, foram denominados por Mário de Andrade (1966) como dança dramática, cuja especificidade é a realização de bailados coletivos que obedeçam a um tema característico tradicional, e que tenham o formato de obra musical constituída por meio da apresentação de coreografia seqüencialmente ordenada, também conhecida por suíte. ${ }^{37}$

A marujada, uma espécie de congado, também se faz presente na vida dos moradores da comunidade, porém se modificou muito com o tempo, afirma Suzana Menezes Macedo, musicista, cantora e compositora que atualmente reside em Lavras Novas. ${ }^{38}$

\footnotetext{
${ }^{37}$ ANDRADE, M. Danças dramáticas do Brasil. São Paulo, Martins, 1966.

${ }^{38}$ Suzana Menezes Macedo é natural de Belo Horizonte, reside em Lavras Novas desde 1980, onde é musicista, cantora e compositora. Suzana teve Lavras Novas como tema de seu primeiro cd, chamado Curdiá. A cantora trabalha, principalmente com música regional.
} 
"Eu cheguei em Lavras Novas em 1980, há 30 anos. Quando eu cheguei aqui eu encontrei a Marujada, e achei interessante porque eram várias manifestações de congado, de devoção a Nossa Senhora dos Prazeres. Eu conheci o Moçambique, o Congado, Catopé, Candômi, mas eu não conhecia bem a Marujada, e eu vim encontrar aqui uma Marujada quase completa, com quase todos os elementos de uma verdadeira Marujada, a partir da pesquisa do Mário de Andrade. A Marujada é uma manifestação muito rica, mesclada de várias culturas. É um tipo de congado, é um dos tipos de congado." 39

A marujada pode ser considerada uma manifestação popular muito rica por ser uma mescla de várias culturas. Este tipo de congado mescla a religiosidade negra com poemas ibéricos, transportando os mais diversos temas para uma atitude dentro de um navio. Em Lavras Novas, o congado e a marujada estão ligados a temas religiosos, na maioria das vezes.

Suzana Menezes Macedo faz um trabalho de resgate da marujada na comunidade, através da criação de um grupo chamado Nananã ${ }^{40}$, que reúne várias mulheres.

"Quando eu cheguei aqui em 1980, ela não era cantada a mais de sessenta
anos. Porque houve um trabalho da Igreja Católica de expurgar toda
manifestação folclórica, assim as manifestações de congado foram
relegadas aos terreiros. Já havia um decreto do rei de Portugal de abolir
essas, essas festas, por causa da sensualidade delas. A Marujada é muito
sensual também. Só mais tarde o Papa João XXIII vinte e três, no Concílio
do Vaticano Segundo, exige que as igrejas abram as portas novamente a
todas as manifestações folclóricas, mas a igreja não teve interesse em
divulgar isso. Quando isso ocorreu o pessoal daqui já havia relegado a
Marujada a um terreiro, um determinado terreiro de uma certa casa daqui.
Então eles não tinham coragem mais de cantar perto da igreja, nem na
frente da igreja, tinham medo de estarem cometendo um sacrilégio, pois a
igreja passou a abominar estas manifestações e falava em severos castigos
de Deus. Agora nós tentamos, juntas, resgatar a marujada na comunidade."
41

Como se pode notar, a influência do negro em Lavras Novas é muito forte, assim como em todo o estado de Minas Gerais, onde as manifestações podem ser consideradas afro-católicas. A ordem cultural que foi imposta ao negro em Minas Gerais, pela Igreja

\footnotetext{
${ }^{39}$ Fonte: trabalho de campo realizado em 18 de outubro de 2009.

${ }^{40} \mathrm{O}$ grupo NaNaNã surgiu em 1986 com um trabalho com as crianças da comunidade, posteriormente se empenhou a resgatar a tradição musical da Marujada, que estava quase se perdendo na comunidade. Hoje o grupo NaNaNã funciona ao lado da casa de cultura Dedela.

${ }^{41}$ Fonte: trabalho de campo realizado em 18 de outubro de 2009.
} 
Católica, não o fez perder suas raízes. Os brancos organizavam irmandades para os negros, afirmando ser para afastá-los da feitiçaria, porém, os negros levaram para a Igreja muitos dos elementos de seus antigos rituais de louvor a seus orixás.

Considerando a vigilância dos feitores da Igreja, o negro elaborou um mecanismo próprio de resistência às imposições católicas que se valia da dissimulação. A identificação entre Nossa Senhora do Rosário e a tradição africana, por exemplo, se tornou possível devido à semelhança com que os brancos e os negros consideram as suas "deusas" como fonte de vida e de criação. Em Lavras Novas pode-se fazer a mesma analogia em relação aos cultos prestados a Nossa Senhora dos Prazeres. ${ }^{42}$

As religiões propriamente africanas, como o candomblé, atualmente não são encontradas no distrito, visto que os costumes que restaram destas religiões foram relegados aos terreiros e tidos como sacrilégio perante a irmandade. Porém, segundo relatos de moradores, existia um terreiro na comunidade: o terreiro do Pai Joel. Segundo Suzana Menezes Macedo ${ }^{43}$, logo que ela chegou a Lavras Novas o terreiro se extinguiu devido à morte de Pai Joel. Não há como saber muito a respeito deste terreiro e como ele funcionava, pois os moradores não gostam de falar sobre o assunto. Se afastam dele como se afastassem do pecado.

Além disso, pode-se notar a influência africana na vestimenta, principalmente nos moradores mais velhos: muitas mulheres usam ainda roupas feitas de chitão, algumas ainda usam pitucas nos cabelos ${ }^{44}$, saias rodadas e roupas bem coloridas. Dentre as mais velhas é comum vê-las usando calça comprida por baixo das saias, vestimenta típica das negras escravizadas, que usavam estas roupas para trabalhar nas minas de ouro.

Outro modo de influência que se pode perceber na comunidade de Lavras Novas está na criação de máscaras como peças de decoração. As máscaras africanas são encontradas para serem vendidas como artesanato em muitas lojas, porém a maioria delas já é feita sob encomenda, para atender a demanda. Apesar desta produção já ser direcionada ao consumo ainda existem artistas que fabricam as máscaras para exposição e mesmo que para venda, artesanalmente, não em larga escala.

\footnotetext{
${ }^{42}$ NÚBIA P. M. Negras raízes mineiras: Os Arturos. 2a ed. Belo Horizonte: Mazza: 2000. p. 140-143.

${ }^{43}$ Fonte: trabalho de campo realizado em 18 de outubro de 2009.

44 A pituca é um coque feito com grampos, quase na testa.
} 
Há presença da cultura africana na culinária, de onde surge o que se chama de comida mineira típica. O negro trouxe para Minas o angu, a couve, as broas de fubá, a receita típica de frango com quiabo, o feijão tropeiro, as carnes ensopadas, as carnes refogadas na cachaça, todas facilmente encontradas nos fogões a lenha de Lavras Novas, e em seus muitos restaurantes abertos depois do florescimento turístico na região.

\section{4 - A chegada da Luz elétrica, da mídia e a transformação da região em pólo turístico.}

Com a decadência da atividade mineradora na região de Lavras Novas, no final do século XVIII, a população que permaneceu na região, em sua maioria escravos alforriados, passou a viver em uma comunidade praticamente fechada, onde era praticada a agricultura de subsistência. A luz elétrica só chegou à localidade em 1970, e a partir daí o distrito foi, aos poucos, recebendo os primeiros veículos de comunicação de massa elétricos. Antes disso poucos moradores possuíam apenas os rádios de pilha e, segundo eles, o sinal era muito ruim.

Em 1970, a região começou a se modificar não apenas pela chegada da luz elétrica, mas também pela chegada da Fazenda do Manso, com o cultivo de chá. Suzana Menezes Macedo conta que:

\footnotetext{
"Quando eu cheguei aqui, em 1980, aqui era um aglomerado de pessoas que há mais de trezentos anos, viviam hermeticamente fechadas. Com um linguajar próprio, com um jeito de se vestir próprio, a televisão não tinha chegado ainda, e nenhum corpo estranho conseguia viver no meio deles, a não ser que fossem padre ou freira, que fossem católicos. Eu mesmo demorei muito para me enturmar aqui, demorou. Em 1980 não havia chegado a televisão aqui ainda e não havia também, praticamente nenhum turismo aqui em Lavras Novas, era raro." ${ }^{45}$
}

Nair Alves Viana, nascida em Lavras Novas e hoje com 90 anos, conta que nos últimos 20 anos a localidade mudou muito em relação ao que era na época de sua juventude, que antigamente as coisas eram bem diferentes:

\footnotetext{
${ }^{45}$ Fonte: trabalho de campo realizado em 17 de outubro de 2009.
} 
"Aqui, no meu tempo de moça, o transporte era feito de mula, não tinha ônibus não, e essa estradinha que sai de Ouro Preto e vem pra cá era muito ruim. Não vinha quase ninguém pra cá não. Aqui era só mato, as casas não eram juntinhas assim não. Depois que chegou a luz que começaram a aumentar as casas. Era triste e bonito, que era muito simples. Como não tinha luz a noite a gente se reunia nas portas das casas, do lado de fogueiras, para ouvir as histórias que os mais velhos contavam, os causos. Com o tempo isso foi acabando.". ${ }^{46}$

Depois da chegada da luz elétrica à comunidade, e com a facilitação da chegada de meios de transportes ao distrito, os primeiros turistas começaram a chegar, principalmente vindos de Ouro Preto e Belo Horizonte. O turismo ecológico na região foi ficando conhecido, o turismo cultural foi aumentando, e com isso chegando as primeiras grandes pousadas, hotéis e sendo construídas as primeiras grandes casas. Os moradores de Lavras Novas começaram a abrir restaurantes, construir casas para aluguel em épocas de temporada, alugar cômodos em suas casas, abrir lojas de artesanato, tudo apara se adaptar a crescente demanda dos turistas e conseguirem também lucrar com esta atividade. Os donos dos grandes hotéis, pousadas e dos grandes restaurantes, não são nativos, são empreendedores vindos de outras partes do Brasil que conheceram a região e enxergaram nela um grande potencial turístico.

A mudança no cenário de Lavras Novas foi muito rápida, em pouco mais de 10 anos a localidade, que possui cerca de 1.500 habitantes, passou a receber um grande contingente de turistas, e se tornou um pólo turístico nacional.

O turismo é, hoje, uma das principais alternativas econômicas dos moradores, que antes viviam, sobretudo, do artesanato de taquara e cipó e que agora possuem estabelecimentos, muitas vezes em suas próprias residências, destinados à venda do artesanato local, bem como a atividades culturais e de entretenimento, como por exemplo, a Casa de Cultura Dedela e o Espaço Cultural Era Uma vez, onde são montadas e apresentadas peças de teatro voltadas à divulgação da cultura local e à conscientização ambiental, com participação ativa dos moradores, que formam o grupo de teatro Balaio de Gatos, coordenado pelo ator Jonas Bloch, também dono de uma pousada na comunidade.

Hoje são cerca de 30 pousadas de alto padrão, 30 pousadas populares, além dos muitos quartos alugados pelos moradores da comunidade em suas casas. Nas épocas de alta

\footnotetext{
${ }^{46}$ Fonte: trabalho de campo realizado em 18 de outubro de 2009.
} 
temporada, como reveillon, feriados nacionais e carnaval, a maioria dos moradores aluga também seus quintais como área de camping. As lojas de artesanato, de lembrancinhas, e os barzinhos só funcionam em épocas de feriado e finais de semana, estando fechados durante a semana, quando geralmente seus donos trabalham em outras atividades.

Porém, existe certa divisão entre a parte pobre e a parte rica da comunidade. As pousadas de alto padrão econômico ficam localizadas bem no início do distrito (conhecido como parte alta), distantes da comunidade (conhecida como parte baixa). Algumas grandes pousadas chegam a ter diárias de mais de 2.000,00, outras possuem gourmet francês, japonês, italiano, uma delas chega até a oferecer banhos de ofurô. No ano de 2006 as pousadas e restaurantes da parte alta da localidade promoveram o primeiro festival de queijos e vinhos chamado Safras Novas ${ }^{47}$, que reuniu mais de 5.000 pessoas, para incentivar o turismo na região, contudo vinhos e queijos não fazem parte da culinária típica de Lavras Novas. De acordo com Suzana Menezes Macedo :

\begin{abstract}
"Os donos das pousadas ricas fizeram uma coisa arbitrária. Os moradores mesmo da comunidade não tiveram participação nenhuma na organização do Safras Novas. Um evento em Lavras Novas com comida típica italiana, francesa, é um absurdo. Ainda levaram nossas mulheres daqui de baixo para cozinharem às ordens dos chefes internacionais trazidos para cá. Nós, moradores da parte de baixo fomos vistos só como espetáculos de dancinha, musiquinha, sem participação efetiva nenhuma. O pior problema é que isso incentiva este tipo de turismo. Pelo menos os moradores daqui de baixo promoveram, na mesma época, um outro festival chamado Safras Velhas, como forma de protesto pela maneira arbitrária como as coisas foram feitas. " 48
\end{abstract}

O turismo gastronômico na comunidade vai muito além dos festivais, seu atrativo, muitas vezes, se encontra propriamente na simplicidade da cozinha mineira, nos pequenos restaurantes improvisados nas cozinhas das casas dos moradores, ou mesmo nos restaurantes e bares mais simples, montados para atender a demanda turística.

O ecoturismo também tem ganho muita visibilidade na comunidade. Os principais atrativos naturais da localidade de Lavras Novas são: Cachoeira de Nossa Senhora dos Prazeres, Represa do Custódio, Cachoeira do Custódio, Cachoeira dos Três Pingos,

\footnotetext{
${ }^{47}$ Notícias sobre o festival Safras Novas nos jornais O Tempo, Hoje em Dia e Estado de Minas. As reportagens se encontram nos anexos 1,2 e 3.

${ }^{48}$ Fonte: trabalho de campo realizado em 17 de outubro de 2009.
} 
Cachoeira do Rapel, Cachoeira do Pocinho, Cachoeira dos Namorados e Cachoeira do Falcão. Também chama a atenção à vista da mata preservada, com destaque para as belíssimas florações de quaresmeiras.

Hoje, existem 3 pequenas empresas de turismo ecológico e esportes radicais na comunidade, todas as 3 formadas por moradores de Lavras Novas, contudo outras empresas maiores, principalmente de Ouro Preto e Belo Horizonte, também atuam no distrito.

A divulgação dos atrativos locais, através das freqüentes reportagens em jornais e revistas de circulação nacional, documentários televisivos e internet só veio a incrementar a demanda turística no povoado, consolidando o processo de globalização e mercantilização. Lavras Novas conta com um site próprio, destinado à divulgação dos atrativos turísticos naturais, culturais e à conscientização ambiental. ${ }^{49}$

Apesar da preocupação do site local em preservar o ambiente de Lavras Novas, a grande quantidade de turistas e o crescimento desordenado da comunidade tem causado diversos problemas ambientais, tais como:

- Descaracterização do patrimônio arquitetônico, devido a construção desordenada de novas casa e pousadas.

- Ocupação de locais inapropriados para construção civil, como locais de acentuado declive, em topos de morros.

- Retirada da vegetação para construção de novas edificações, provocando muitas vezes compactação do solo e erosão.

- Poluição sonora devido à grande quantidade de veículos e de turistas, principalmente em períodos de alta temporada.

- Poluição do ar da comunidade quando existe um trânsito excessivo de veículos, nas épocas de alta temporada, causando, inclusive, congestionamentos nas ruas.

- Contaminação das águas pelo aumento constante de dejetos no esgoto sanitário.

- Acumulo de lixo nas vias urbanas e nos principais pontos de turismo ecológico, como cachoeiras e trilhas, principalmente na alta temporada.

\footnotetext{
${ }^{49} \mathrm{O}$ site oficial de Lavras Novas é: http://www.lavrasnovas.com.br
} 
- Problemas sociais por motivo de uso de entorpecentes por alguns turistas. $^{50}$

Hoje os turistas que chegam a Lavras Novas são atraídos não só pelas belezas naturais, mas também pelas festas religiosas marcadas pelo sincretismo religioso, como a Festa do Divino e de Nossa Senhora dos Prazeres, a Festa Junina, a Semana Santa, etc.

Considerando o constante aumento do turismo em Lavras Novas e a atividade como principal fonte de renda da população, este trabalho analisa a forma como este novo panorama globalizado se miscigena com a tradição local, e os possíveis resultados desta coexistência, tomando as festas populares como uma espécie de termômetro para estudar as mudanças ocorridas na comunidade.

${ }^{50}$ GOMES. L.M.R, GUIDO. E.S, RIBEIRO. A, GRIFFITH. J. J. Turismo - Visão e Ação - volume 5 - n.3 set./dez. 2003 


\section{CAPÍTULO II: \\ IDENTIDADE CULTURAL, MÍDIA E TURISMO: AS FESTAS POPULARES SUBALTERNAS ENTRE A RESISTÊNCIA E A REIFICAÇÃO}

Neste capítulo é feita uma análise da atual situação das culturas populares subalternas de forma a procurar entender seu caráter a partir da teoria marxista, dentro do atual contexto sócio-cultural globalizado. A presente discussão abordará o atual contexto histórico sob o viés da teoria da sociedade de massas e da indústria cultural, considerando as culturas populares subalternas, bem como as festas populares subalternas e sua arte como novos produtos para indústria cultural do turismo justamente por representarem a possibilidade de um locus de resistência ao hegemônico.

Procura-se entender como as culturas populares subalternas, no microcosmo das festas populares, vêm sendo deformadas através da parceria entre indústria do turismo e mídia. Entender como e porque acontece a criação de lugares aparentemente autônomos e inabitados, pela propaganda de turismo, para que, através disso, possam-se explicitar descaracterizações que ocorrem devido ao incentivo midiático à exploração turística predatória. A partir disso, se torna possível distinguir o turismo predatório (incentivado pela mídia e prejudicial às comunidades e aos turistas), do turismo emancipador (transformador para ambas as partes).

Considerando estes pressupostos, faz-se possível uma abordagem sobre a identidade sócio-cultural das comunidades inseridas em uma sociedade transnacional, padronizadora de desejos e valores sociais, e sobre as formas de influências que se manifestam dentro do universo simbólico das pequenas comunidades, como no caso de Lavras Novas.

Dentro da discussão de conceitos como o de comunidade, memória coletiva e oralidade,se tornará mais referenciado o debate sobre a relação entre culturas populares subalternas, consumo padronizado, mídia e turismo, nos atendo ao universo das festas populares, que são o objeto de pesquisa deste trabalho.

Pretende-se concatenar, neste capítulo, as diferentes formas como as culturas populares subalternas, e mais especificamente, suas festas, podem ser entendidas, significadas, transformadas, des-significadas, ou mesmo descartadas. 


\section{1 - O hegemônico e o subalterno: uma análise considerando o caráter dinâmico das culturas populares.}

Quando se fala em cultura, hoje, é necessário referir-se sobre que tipo de abordagem, que tipo de cultura, se quer enfatizar. É como se a palavra cultura tivesse se diluído em diversos significados, que muitas vezes vêm de maneira a encobrir, ou mesmo obscurecer alguns sentidos. É um diluir não nos vários significados que a palavra cultura pode ter, dentro dos diversos contextos em que pode ser usada, mas sim no sentido de criarem-se vários planos para entendimento de cultura mesmo quando se fala em cultura como um bem de uma sociedade ou de um povo.

Raymond Williams (2007) define cultura de uma forma processual em seus vários significados, porém considera que a palavra possui significados que podem gerar confusão, mas nem por isso devem ser deixados de lado, pois a evolução das significações podem dizer muito sobre os contextos sociais. "Diante dessa complexa e ainda ativa história da palavra cultura, é fácil reagir com a escolha de um sentido "verdadeiro", "adequado" ou "científico" e descartar outros sentidos por serem vagos ou confusos. "(WILLIAMS, 2007: 122). Não é isto o que pretende este trabalho. Este trabalho visa situar sua conceituação de cultura como as formas de vida reais e cotidianas das culturas populares subalternas, para que possam ser entendidos os reflexos de sua realidade em todas as suas manifestações. Deseja-se aqui estreitar os domínios do entendimento da palavra cultura para apenas um âmbito, não afirmando que esta seja a única conceituação exata, porém escolhendo-a como objeto pra esta pesquisa no microcosmo das culturas populares subalternas.

Mas por que usar o termo culturas populares subalternas, e não somente cultura popular? Para Ferreira o termo cultura popular "... se apresenta ambíguo e limitado para dar conta da complexidade do universo compreendido nesta realidade." (FERREIRA, 2006: 107). O termo cultura popular, no singular, pode gerar equívocos, o mais comum é dar o mesmo sentido remetido à palavra folclore. Para Canclini :

"El folclore realiza una doble reducción: de la pluralidad y la diversidad de las culturas populares a la unidad del "arte" o la "musica" nacionales; de los procesos sociales a los objetos o a la expresión cosificada que adquirieram em momentos passados." (CANCLINI, 1988: 45) 
A definição de culturas populares subalternas vai além da definição de folclore, da unidade, se realizando na pluralidade, e pode ser claramente entendida através da definição de Ferreira :

"O popular subalterno seria então aquela produção cultural que apresenta uma concepção particular do mundo e da vida, refletindo o caráter coletivo dos processos, manifestações e bens do próprio povo. Esta produção não é necessariamente guardada por grupos ou indivíduos pertencentes às classes subalternas do ponto de vista da produção econômica, desde que represente a visão do mundo e os interesses que são próprios a estas classes. Resumidamente:

$1^{\circ}$ - O subalterno deve ser considerado cenário policlassista, que inclui, mas transcende o especificamente proletário;

$2^{\mathrm{o}}$ - O popular é próprio das classes subalternas;

$3^{\circ}$ - O popular caracteriza-se como espaço onde coexistem concepções do mundo herdadas do passado (tradições) e elementos modernizantes, do mundo em formação, como conseqüências das atuais condições de vida das classes subalternas;

$4^{\text {o }}$ - O popular caracteriza-se ainda como cenário contraditório no qual coabitam elementos culturais conservadores readaptados e ressignificados nas concepções de mundo das elites dominantes e elementos transformadores, derivados da práxis social das classes subalternas.

$5^{\circ}$ - O popular é, por definição, histórica e essencialmente oposto ao oficial ou, pelo menos, diferente dele."(FERREIRA, 2006: 108-109).

É importante tratar a cultura popular sempre enquanto pluralidade, enquanto diversidade: culturas populares subalternas. O plural é importante justamente para afastar deste conceito a unidade intrincada no conceito de folclore. Sobre a importância do uso do plural Canclini afirma que :

"Para la mayor parte de la antropología existem culturas populares (El uso del plural aqui es importante) porque cada grupo da respostas diferentes a sus necessidades vitales. La respuesta tácita del folclore es que las culturas populares se forman por la conservación de tradicones em las que los pueblos condensan su visón del mundo e encuentram su identidad. El marxismo, em su versión clásica, sostiene que las culturas populares son el resultado de la división de la sociedad em clases cubren sus privilegios." (CANCLINI, 1988: 49).

É exatamente no âmbito tomado por Canclini que este trabalho entende as manifestações das culturas populares subalternas e a forma de suas relações com a cultura 
globalizada. Para isso é necessário entender como e porque existem as culturas populares subalternas. Segundo Canclini:

"... existen culturas populares porque la reproducción desigual de la sociedad genera: a) una apropriación desigual de los bienes económicos e culturales por parte de diferentes clases y grupos em la producción y en el consumo; b) uma elaboración propia de sus condiciones de vida y uma satisfacción específica de Sus necesidades em los sectores excluídos de la participación plena em el producto social; y c) uma interacción conflictiva entre las clases populares com las hegemônicas por la apropriación de los bienes."(CANCLINI, 1988: 49).

Considerar o conceito de hegemonia no sistema capitalista de classes é imprescindível para entender a relação de conflito entre as classes subalternas e a hegemônica. Não que as culturas populares subalternas se localizem fora do plano massificador do sistema (pois são fundadas em sua base e se articulam em suas estruturas), mas pode-se ainda considerá-las uma possibilidade de resistência ao hegemônico e ao massivo, no sentido de que sua forma de produção se dá nos processos de adaptação e ressignificação dos quadros dados pelo sistema, se expressando na cotidianidade.

A hegemonia supõe a existência de algo totalizante, que não é somente superestrutural. Algo que rege e subordina ao mesmo tempo em que não é determinante, algo que perpassa toda a sociedade. Segundo Williams, fundamentado em Gramsci, a hegemonia “... constitui a substância e o limite do senso comum para muitas pessoas sob sua influência e corresponde a realidade da existência social muito mais claramente do que quaisquer noções derivadas da fórmula de base e superestrutura.” (WILLIAMS, 2005: 216) ${ }^{51}$ Para o autor:

“... Essa noção de hegemonia como algo no qual a consciência de determinada sociedade está profundamente imersa parece fundamental. E a hegemonia leva vantagem sobre noções genéricas de totalidade, pois ao mesmo tempo enfatiza o fato da dominação".(WILLIAMS, 2005: 216).

É justamente na potencialidade de antagonismo à hegemonia que as culturas populares subalternas, suas manifestações, suas festas e sua arte se situam. É importante

\footnotetext{
${ }^{51}$ Aqui o autor refere-se ao sentido idealista de concepção social, o qual consideraria como fórmula para entendimento social os conceitos determinantes da base sobre a superestrutura, fugindo assim de uma forma de concepção dialética.
} 
não confundir hegemônico com massivo, pois, o massivo está englobado pelo hegemônico. O hegemônico possui estruturas internas complexas, não é estático e nem determinado ou determinante, é dialético com o que produz e com o que o produz, e assim concomitantemente.

Este trabalho coloca as culturas populares subalternas em potencial antagonismo ao hegemônico em primeira instância, e à cultura de massas em segunda, pois a hegemonia perpassa todos os planos de uma sociedade, inclusive o massivo. Além disso, é importante considerar a existência de elementos da cultura de massa dentro do popular e da cultura popular dentro da cultura de massa, pois ambas se situam dentro da base e da superestrutura social.

Quando se fala na existência de uma base e de uma superestrutura é necessário concernir esta análise no âmbito das diferenciações entre os dois conceitos e fugir de qualquer espécie de entendimento que se aproxime da definição de uma base determinante e de uma estrutura determinada, é necessário lembrar que a base para qualquer análise de cunho marxista é o método dialético e o método materialista histórico.

$\mathrm{O}$ entendimento dialético dos conceitos de base e superestrutura se faz imprescindível para a compreensão da atuação dos mecanismos massificadores dentro do plano popular, para que não se caia em um modelo reducionista e determinista de dominação. Para diferenciarmos estes conceitos de qualquer tipo de conceito simplista podemos recorrer à explicação proposta por Raymond Williams:

"Nós temos que reavaliar "superestrutura" em relação a um determinado escopo de práticas culturais relacionadas, e não como um conteúdo refletido, reproduzido ou especificamente dependente de uma base. E, principalmente, nós temos que reavaliar "base" não como uma abstração econômica ou tecnológica fixa, mas como as atividades específicas de homens em relações sociais e econômicas reais, que contêm contradições e variações fundamentais, e por isso estão sempre em estado de processo dinâmico." (WILLIAMS, 2005: 214).

Tal conceituação de Raymond Williams se torna facilmente entendida a partir destes conceitos. Assim Lukács afirma que:

"Aos olhos do marxismo vulgar, a superestrutura é uma conseqüência mecânica, causal do desenvolvimento das forças produtivas. O método 
dialético não permite semelhante relação. A dialética nega que possam existir em qualquer parte do mundo relações de causa e efeito puramente unívocas: ela reconhece mesmo nos dados mais elementares do real complexas relações de causa e de efeito. E o materialismo histórico acentua com particular vigor o fato de que, num processo tão plurilateral e cheio de estratificações como é o processo da evolução da sociedade, o processo do desenvolvimento histórico-social só se concretiza, em qualquer de seus momentos, como uma intrincada trama de interações." (LUKÁCS, 1968: 16).

É, mais precisamente, dentro desta conceituação histórica e dialética que este trabalho entende a forma como se dão as interações sócio-culturais e de mercado com as culturas populares subalternas, considerando a mídia e o mercado de turismo como fortes armas da cultura hegemônica, que a todo tempo tentam englobar as formas populares resistentes em seus domínios, de forma a obter controle e lucro através delas.

\section{2 - As festas populares como objeto de estudo}

Antes da existência dos modernos veículos de comunicação de massa, as festas constituíam-se em um importante momento da vida pública. Nas festas o indivíduo reafirmava seu pertencimento a certa comunidade ou grupo e sua identidade sócio-cultural. Segundo Ferreira (2000):

"A festa era também um lugar simbólico através do qual eram veiculados os valores e as crenças do grupo, transformando-se, portanto, no principal lugar onde afloravam os conflitos de significado na disputa pelo monopólio da informação e, até mesmo do controle social." (FERREIRA, 2000: 136)

A festa se manifesta em um tempo que rompe com a cotidianidade, ao mesmo tempo em que está diretamente ligado a ela. A cotidianidade e o tempo festivo se completam dialeticamente para produzirem a reafirmação mútua dos valores identitários de uma comunidade. O tempo da cotidianidade é interrompido no momento da festa, para ser reafirmado coletivamente, e ao mesmo tempo vem ratificar a existência identitária dos indivíduos perante a sua cultura.

Podem-se relacionar as festas populares subalternas dentro do âmbito da cotidianidade na cultura popular, não como um prolongamento de tal, mas, muito antes, 
como "uma inversão da realidade cotidiana, na medida em que reproduz o tempo mítico". (FERREIRA, 2006: 63)

A festa resgata as experiências culturais vividas por um grupo desde longínquas épocas, trazendo-as para a atualidade. Ao mesmo tempo, os costumes mais intrincados à comunidade, vivenciados em seu dia-a-dia, afloram. Os valores e tradições rememorados pelas festas, ao mesmo tempo em que são reafirmados pela comunidade, se abrem para a incorporação de novas formas de relação com a realidade, para incorporação de novos elementos, pois as culturas populares subalternas e suas festas não possuem caráter estático, mas sim dinâmico.

"Destes dois aspectos existentes no fenômeno festa é possível extrair os elementos de identidade mais significativos de uma determinada cultura, bem como entender estes elementos como um sistema de comunicação que permite ao observador avaliar como o passado e o presente se articulam no interior desta cultura e as várias formas de identidades que são ao mesmo tempo ressignificadas, assumindo novos aspectos." (FERREIRA, 2000: 137)

Considerando as festas como manifestações populares subalternas formadas por vários elementos comunicacionais, é possível entender as diversas tentativas de relegar o caráter comunicacional da festa à inexistência através de sua omissão, colocando-o em um conglomerado de manifestações pontuais que simplesmente possuam valor de mercado. Trazer o tempo das festas para a linearidade é quebrar com a dialética intrincada aos elementos identitários comunicacionais presentes nas festas, é trazer a retórica econômica fetichizada para o âmbito das tradições. Segundo Jésus Martín-Barbero:

"O tempo cíclico é um tempo cujo eixo está na festa. As festas com sua repetição, ou melhor, com seu retorno, balizam a temporada social nas culturas populares. Cada estação, cada ano, possui a organização de um ciclo em torno do tempo denso das festas, denso enquanto carregado pelo máximo de participação, de vida coletiva. A festa não se constitui, contudo, por oposição à cotidianidade; é, antes, aquilo que renova seu sentido, como se a cotidianidade o desgastasse e periodicamente a festa viesse recarregálo novamente no sentido de pertencimento à comunidade". (MARTÍNBARBERO, 1997: 130) 
Neste sentido, Martín-Barbero (1997) afirma que o surgimento do mercado (consideramos aqui também o mercado turístico) deu origem aos processos de "enculturação: a transformação do sentido de tempo que, abolindo o cíclico, impõe o linear, centrado sobre a produção, a transformação do saber e seus modos de transmissão..." (MARTÍN-BARBERO, 1997:130 ) Para o autor:

"O sentido do tempo nas culturas populares será bloqueado por dispositivos convergentes: o que de-forma as festas e o que as desloca, situando na produção o novo eixo de organização da temporalidade social. A deformação opera pela transformação da festa em espetáculo: algo que já não é para ser vivido, mas visto e admirado." (MARTíN-BARBERO, 1997: 131)

É necessário entender que as festas populares, por representarem um espaço potencial de resistência ao hegemônico, passam a ter seus elementos como alvos constantes da indústria cultural, da indústria de turismo e da mídia, que com suas interferências, aparentemente inocentes, tentam, aos poucos, transferir o valor das festas que se encontra no âmbito do simbólico e mítico para o material e mercadológico.

Porém, é necessário entender que a dessignificação, e a espuriação dos conteúdos populares não acontecem somente com o respaldo dos mecanismos midiáticos. A massificação do simbólico se encontra em um plano base que perpassa todas as esferas da sociedade, podendo ser encontrada, principalmente, nos pilares da vida social de um indivíduo, em sua educação formada dentro dos padrões capitalistas de divisão de classes.

O produzir lucro para o funcionamento do sistema não depende somente de mecanismos operacionais, mas principalmente de moldar as consciências individuais para irem de encontro aos interesses industriais. A mídia constitui-se em um importante aliado no molde de consciências, porém os indivíduos, através do sistema social, também são levados a ratificarem os conteúdos midiáticos, se não os efeitos da mídia não seriam significativos. A massificação midiática advém da massificação social, bem como se pode afirmar que muito da massificação social se torna muito mais normalizada através da ação das mídias. De acordo com Martín-Barbero:

"No solapamento desta consciência a escola vai desempenhar um papel preponderante. A escola não pode cumprir seu ofício, isto é, introduzir as 
crianças nos dispositivos prévios para o ingresso na vida produtiva, sem desativar os modos de persistência da consciência popular. Por isso a escola funcionará sobre dois princípios: a educação como preenchimento de recipientes vazios e a moralização como extirpação dos vícios." (MARTÍN-BARBERO, 1997: 108)

Em consonância com a massificação social e midiática se torna mais fácil entender que a descaracterização das culturas populares subalternas, bem como de suas festas criam uma tendência à extirpação total de manifestações que realmente possuam valor simbólico dentro das localidades onde são praticadas. É um processo que a longo prazo visa englobar nas vias de mercado todas as produções populares.

Pequenas transformações, vistas como "melhorias" nas festas populares (principalmente para atender o mercado turístico), aos poucos vão impondo as comunidades uma nova maneira de ser, transformando o caráter tradicional, simbólico e comunicacional das festas em um simples padrão de gosto hegemônico, onde o bonito e o feio seguem modelos de vitrines para cada tipo de festa.

Segundo Martín-Barbero (1997), a cultura oficial, erudita e católica, já na Idade Média, por se sentir desafiada pela cultura popular, reprimiu a mesma, e com o tempo passou a considerar as formas de representação populares, diferentes da cultura oficial e clerical, não apenas como (de forma maniqueísta) ruins e erradas, mas como tolices sem sentido. Muito do que foi relegado à cultura popular subalterna como tolice consta na contemporaneidade de diferentes formas, onde o popular só tem serventia como entretenimento, perdendo seu sentido de pertencimento identitário para um sentido comercial. O sentido mercadológico desloca as manifestações populares e os costumes angajados em vivência de comunidades e culturas específicas para um espaço-temporal sem raízes e sem comprometimento com qualquer tipo de experiência coletiva.

Entendendo a complexidade do fenômeno festa enquanto objeto comunicacional de estudo, a tarefa de examinar o que foi incorporado à cultura local naturalmente, como elemento de inovação, e os elementos que podem ser considerados como descaracterização cultural, se torna difícil, necessitando de analises profundas sobre a identidade sóciocultural. Assim, se torna primordial, a análise entre a cotidianidade da população e suas festas, a análise das correspondências entre o tempo mítico e a vivência do dia-a-dia. 
É importante relembrar que o que deve ser estudado através das festas não são, somente, os rituais que sobreviveram ao tempo e as modificações (sempre relegadas a espuriações do mercado). O que é importante ser pesquisado são, sim, as modificações ritualísticas das festas, juntamente com o que foi preservado tradicionalmente pela comunidade, para entender, como assinala Martín-Barbero (1997), os motivos pelos quais as festas continuam a existir em uma comunidade e qual sentido simbólico e de pertencimento relegado a elas pela população em seu momento atual.

Segundo ele, não se pode enxergar a cultura popular como um simples campo de resistência ao massivo (não que se negue esta afirmação), propondo um retorno às origens legítimas ou achar que tudo que é massivo não passa de vulgaridade e não corresponde a cultura popular, mas sim à alienação.

$\mathrm{O}$ autor, apesar de embutir em seus trabalhos certa abordagem funcionalista (a qual não é intuito deste projeto) considera que a cultura popular pode estar presente no massivo e o massivo presente na cultura popular. Admitindo tal afirmação, esta pesquisa acredita na coexistência de elementos massivos no popular e do popular no massivo, contanto que a transição de elementos de um a outro não transforme seu caráter conceitual básico.

Nesta pesquisa será considerado este argumento, porém, sem desconsiderar as culturas populares subalternas como o locus privilegiado da resistência cultural e o massivo como forma de deformação cultural. $\mathrm{O}$ que não se pretende é cair no reducionismo e na unilateralidade.

Discorrendo sobre a destruição de estilos específicos de vida para sua transformação em algo novo, dentro da cotidianidade do popular, Stuart Hall afirma que "de um jeito ou de outro, o povo é, freqüentemente, o objeto da reforma" (HALL, 2006: 132). Afirma ainda que não existe uma cultura popular íntegra, autêntica e autônoma, situada fora do campo das relações de poder e dominação culturais.

Dentro do conceito de cultura popular subalterna proposto por Maria Nazareth Ferreira, esta pesquisa privilegia o estudo das culturas populares subalternas, não como totalmente puras, mas também funcionando como resistência à cultura massificada de mercado, e ao mesmo tempo podendo conter elementos desta cultura, expressos na cotidianidade e nas referências simbólicas. 
É precisamente na investigação sobre a transformação das manifestações de sentido identitário, através dos signos festivos, em performance, que esta pesquisa analisa, no distrito de Lavras Novas, a Festa do Divino e de Nossa Senhora dos Prazeres e a Encomendação das Almas, considerando a influência da chegada das grandes mídias ao distrito, contribuindo para o aumento descontrolado do turismo.

Se se considerar os veículos de comunicação e sua forma alienante de propagar uniformização e padronização através da lógica de mercado, pode-se, então, perceber como as culturas populares subalternas, expostas ao turismo massificado, podem ter sua identidade sócio-cultural fortemente deslocada e deformada. A deformação e o deslocamento podem alterar não só a forma como o significante dos ritos tem importância para o cotidiano da comunidade, mas também afetar a formação da memória coletiva de uma população, que é a base da identidade sócio-cultural das comunidades.

\section{3 - Turismo predatório $X$ turismo emancipador: as pequenas comunidades} como novos destinos.

\subsection{1 - Turismo cultural e identidade}

As vertentes turísticas que têm ganho maior visibilidade e gerado novos investimentos nos últimos anos são as ligadas, principalmente, ao mercado do turismo cultural e ao turismo ecológico ${ }^{52}$. Mas o que explicaria um aumento tão grande de interesse nesta área?

Segundo Ferreira, o cerne da questão se encontra na atual problemática da identidade. $\mathrm{O}$ atual estágio do processo neoliberal tem configurado uma nova realidade, desencadeando discussões que põem em evidência essa questão.

"Uma das conseqüências mais controvertidas da expansão neoliberal é o despertar das identidades. Se na década de 70, deixou-se de pensar as classes sociais para, nos anos 80 , pensar os atores sociais, na década atual, a grande problemática é a discussão das identidades nacional, social e cultural." (FERREIRA, 1995: 65)

\footnotetext{
${ }^{52}$ OMT (2010) Disponível em: http//:www.world-turism.org. Acesso em 25 de maio de 2010.
} 
Segundo ela: “... a identidade humana é, portanto, uma necessidade, e se constrói a partir de três componentes fundamentais: espaço, tempo e movimento".(FERREIRA, 2005: 31-32).

De acordo com a autora, a idéia de movimento é a mais complexa dos três componentes da identidade, pois não trata do movimento da vida humana, mas sim do movimento da vida social, que não experimenta fim, mas é sempre uma continuidade. Desta continuidade surge a necessidade da memória, do entendimento das histórias passadas e da acumulação de experiências, a que se dá o nome de cultura.

Ferreira afirma que, para discutir-se a identidade de um povo, é preciso discutir, primeiramente, a formação de sua identidade nacional, para, posteriormente, prolongar o debate para a identidade cultural.

Historicamente, a idéia de identidade nacional é uma construção do Estado autoritário:

“... este utiliza, na construção da identidade nacional, a idéia do patrimônio cultural, fundamentada nos registros arquitetônicos, nas expressões da arte erudita, nos heróis oficiais, buscando, portanto, suas raízes numa visão elitista de cultura. Claro está que salvaguardar o patrimônio cultural de um povo é atitude de valorizar a memória coletiva desse povo. Mas, à medida em que esse patrimônio não representa toda a sociedade, ou seja, é constituído apenas pelas manifestações culturais das classes dominantes, não resta outra alternativa para as outras manifestações que perdem seus signos de identidade, senão permanecerem fora da representação de identidade nacional. Disto se conclui que a idéia de patrimônio cultural na construção da identidade é uma deturpação do real." (FERREIRA, 2005:32).

Pode-se considerar a idéia de patrimônio cultural como deturpação do real, como apresenta Ferreira, justamente por ter-se a representatividade apenas de uma pequena parcela da população, excluindo as classes populares subalternas.

Hoje as populações são expostas intermitentemente aos meios de comunicação de massa que atuam como expressão cultural, bem como educadores. A presença da cultura globalizante dos meios de comunicação tem causado uma perda de referencial para as sociedades, que se explicita de diferentes modos. 
“... parece que há um temor, uma ameaça de desaparecimento dos signos culturais de identidade destas sociedades. A ação voraz globalizante da cultura planetária traz um sentido de perda dos traços ainda atuais, ainda vivos, que comprovam um passado ainda não morto destas culturas; uma necessidade de apropriar-se de um passado recente." (FERREIRA, 2005: 34-35)

A cultura planetária procura diluir as diferenças, deslocando assim os referenciais próprios de cada grupo. Assim os indivíduos passam, mesmo que inconscientemente, a buscar algum suporte concreto para sua memória histórica, longe da efemeridade própria das veiculações midiáticas.

"Não é por acaso que o mundo assiste, nos dias atuais, a uma verdadeira onda de nascimentos de museus etnológicos, memórias, casas de cultura e outros correlatos. Aparentemente, esses logradouros - os novos museus correspondem a esta imperiosa necessidade de resistir à desestruturação cultural." (FERREIRA, 2005: 37).

Com o constante desaparecimento de suportes concretos, substituídos pelas representações planetárias dos meios de comunicação, esta busca de identidade através destes suportes também aumenta, e hoje ultrapassa a busca por museus e monumentos históricos, chegando até o turismo cultural.

As culturas populares subalternas se transformam em sua relação com os media, porém, apesar disto e de todas as deformações a que estão expostas, ainda representam um potencial locus de resistência, um espaço onde as tradições e a identidade ainda se mostram concretos e vivos. Assim, o turismo cultural, passa a ter como principal foco as pequenas comunidades, justamente por estas se apresentarem, na maioria dos casos, mais afastadas da padronização imposta pela cultura planetária, por mais que estejam inseridas no universo globalizado dos meios de comunicação de massa, e também por as mesmas se apresentarem receptivas ao turismo na esperança de geração de lucro. Dentro das pequenas comunidades as festas populares passam a ser um dos novos destinos dos turistas, por representarem uma celebração da tradição, da identidade.

O panorama pode ser representado através de um eterno ciclo, onde se procura uma solidez ausente nos meios de comunicação e na cultura planetária disseminada por eles, porém o despertar para esta procura se dá, na maioria das vezes, através de mecanismos incentivados pela própria cultura globalizante destes meios, que tem como objetivo 
principal incentivar o turismo cultural como meio de obtenção de lucro, não se importando em incentivar formas predatórias de turismo para gerar capital, transformando as pequenas comunidades em meros palcos para observação.

É justamente neste sentido que se faz extremamente necessário reconhecer as características próprias do que se pode chamar de turismo predatório, para que através de seu conhecimento e esclarecimento, se faça possível a busca por um turismo emancipador.

\subsection{2 - O turismo predatório e sua relação com a descaracterização da identidade sócio-cultural.}

Como já afirmado anteriormente, o turismo é umas das atividades econômicas que mais cresce no mundo, porém, é necessário ressaltar que este crescimento se dá não apenas em número de turistas, mas também em termos de volume de recursos gerados. $\mathrm{O}$ turismo está se constituindo em uma importante fonte de renda para as cidades, estados e países. A importância do turismo como fonte de renda pode ser considerada ainda maior nas pequenas comunidades, que muitas vezes tem suas economias excluídas do processo neoliberal.

Para as pequenas comunidades, como é o caso de Lavras Novas, os reflexos do turismo não se dão apenas nos gastos diretos efetuados pelos turistas, mas também em mudanças significativas para a comunidade, como o aumento da urbanização e das atividades relacionadas a ela, como: transportes, alimentação (restaurantes, bares, lanchonetes, produção e fornecimento de alimentos), serviço de saúde, comércio (farmácias e lojas), informática, acesso aos meios de comunicação de massa, etc.

No caso de Lavras Novas os reflexos do turismo são visíveis. Nos últimos 20 anos as mudanças foram muitas, a maioria delas devido à expansão do turismo na região: mais horários de ônibus; construção de um posto de saúde; antenas de televisão e rádio; mercados que funcionam a semana toda (a maioria dos estabelecimentos destinados a turistas só abre aos finais de semana); a rede de esgoto e água passou por reformas; grande parte dos moradores vive hoje, exclusivamente, do turismo, seja alugando cômodos de suas casas ou mesmo chalés construídos para este propósito, ou no comércio de artesanato, lembrancinhas ou área de alimentação. Dessa forma, grande parte da população que antes 
precisava sair de Lavras Novas e ir a Ouro Preto para trabalhar já não precisa mais sair da comunidade.

Em geral os argumentos utilizados para se falar nos benefícios do turismo para as comunidades são: geração de emprego e lucro para a população, e captação de recursos para o município. Porém, é necessário atentar para a forma como é feita esta distribuição dos lucros, se acontece de forma eqüitativa. Por outro lado, muitas pesquisas têm apontado para problemas decorrentes do aumento do turismo, principalmente nas pequenas comunidades, mostrando que a atividade, além dos benefícios econômicos, pode gerar impactos negativos, como degradação ambiental e descaracterização sócio-cultural. São impactos que atingem não só aos recursos naturais, mas também o patrimônio material e imaterial de uma comunidade. Ferreira denomina turismo predatório:

"Um fator que influencia acentuadamente a perda de identidade cultural pelas classes subalternas é o chamado turismo predatório. É caracterizado como um tipo de turismo realizado de forma nociva para com as comunidades e os espaços envolvidos, sem equilíbrio e sem preocupação com a "capacidade de carga do território", com o limite de tolerabilidade ao desenvolvimento, ou seja, ultrapassando parâmetros condizentes com uma adequada utilização dos recursos envolvidos. Neste tipo de turismo os visitantes agem de forma impositiva sobre os receptores em geral" (FERREIRA, 2005: 108)

Examinaram-se as festas escolhidas para a pesquisa (Festa do Divino Espírito Santo e de Nossa Senhora dos Prazeres e o ritual de Encomendação das Almas, que acontece na Semana Santa) de forma a distinguir o que foi incorporado aos valores tradicionais, "considerando o caráter dinâmico na construção da cultura", e o que pode ser considerado descaracterização cultural. De acordo com o que diz Ferreira:

“... a descaracterização pode ocorrer pelo apelo desenfreado dos próprios turistas, que por sua vez também sofrem influência de padrões culturais freqüentemente divulgados pelos media, formando uma rede de influência da cultura transnacional, que acaba se sobrepondo a cultura local e tradicional." (FERREIRA, 2000: 27).

Assim as pequenas localidades podem cair na lógica do que poderia ser chamado, citando Adorno, de Indústria cultural. De acordo com Adorno (1978), a indústria cultural compreende uma lógica de produção cultural que, entre outros aspectos, trata bens culturais 
como mercadoria. Ela apresenta todas as características de um produto meramente comercial, tem preço, mercado e, por fim, se torna descartável. Ela é criada para o mercado, para as massas. ${ }^{53}$ Portanto as culturas populares subalternas e todas as suas manifestações das pequenas comunidades passam a ter valor de mercado, perdendo muitas vezes seu valor simbólico.

De acordo com Zygmunt Bauman, ao falar sobre os modismos e a criação de necessidades mutantes e constantes pelos mecanismos midiáticos:

\begin{abstract}
"Somos consumidores em uma sociedade de consumidores. A sociedade de consumidores é uma sociedade de mercado. Todos nós nos encontramos dentro dele, e ora somos consumidores, ora mercadorias. Não admira que o uso/consumo de relacionamentos se aproxime, e com rapidez do padrão de uso/consumo de carros, repetindo o ciclo que começa na compra e termina na remoção do lixo." (BAUMAN, 2005: 151-152)
\end{abstract}

Pode-se reportar o que diz Bauman, sobre a velocidade de descarte de objetos e de pessoas, da mudança rápida de necessidades que produzem lixo, para o âmbito das culturas populares subalternas. É o mesmo sentido que Bauman (2005) dá para sua teorização a cerca do que ele chama de encontro veloz.

O que se promove pela indústria cultural do turismo, juntamente com a mídia, hoje, no que chamamos de turismo predatório, é um encontro veloz e superficial com o a cultura do outro. Em relação às culturas populares subalternas os impactos causados por este tipo de encontro são ainda maiores que em relação a outros tipos de consumos descartáveis.

Promove-se um contato curto e inexpressivo, pago, no qual se quer fazer acreditar na captura de uma essência do outro que na verdade não existe para o consumidor, pois a realidade que se visa consumir está fora de seu contexto social e simbólico. Os símbolos da cultura popular subalterna (assim como o que é manifesto pela arte) tornam-se aí objetos que não têm necessidade de significação. Perde-se, muitas vezes, também a necessidade de significação para os próprios produtores das manifestações populares, pois estes passam a produzir cultura unicamente para a venda, como objetos encomendados e modificados aos gostos dos turistas, dos compradores, vislumbrando unicamente o lucro.

\footnotetext{
${ }^{53}$ ADORNO, T.W. A indústria cultural. In: Cohn, G. (Org.). Comunicação e indústria cultural. São Paulo: Nacional, 1978.
} 
O turismo predatório insere as culturas populares subalternas, e suas mais diversas formas de manifestação (como as festas, a música, a culinária e a arte), na lei da oferta e da procura, estimulando modificações culturais que possam parecer lucrativas, sem se importar com a realidade identitária dos nativos das localidades exploradas. As culturas populares subalternas, através do turismo predatório, passam a serem vistas mais pelo viés econômico do que pelo viés da identidade sócio-cultural.

O turismo predatório é muito comum nas pequenas comunidades, geralmente pela falta de planejamento em relação às atividades ligadas ao turismo. A demanda pelo turismo cultural e ecológico é crescente, e não tem sido acompanhada pelo planejamento e administração adequados, muitas vezes por acontecer repentinamente. Localidades que antes viviam de forma pacata, excluídas dos roteiros turísticos regionais, de repente passam a ter sua realidade invadida por milhares de pessoas, que muitas vezes se impõem ao ritmo habitual da comunidade, causando deformações.

O turismo incentivado pela mídia, dentro do sistema econômico moderno, estimulador de descaracterizações, só é possível através da expropriação e exploração da natureza e das sociedades locais, obedecendo a um ritmo, muitas vezes imposto pelos visitadores, onde os interesses estão no consumo final, nos atrativos, e não na experiência do caminho. Os olhares são rápidos, consumidores de paisagens, e não-interativos. Muito deste atual quadro de consumo, se deve ao incentivo midiático do predatório. "A indústria turística, tal como está atualmente, é um dos principais frutos do neoliberalismo e da globalização e se alimenta, principalmente, da expansão do sistema de comunicação" (FERREIRA, 2005: 98), que instiga um padrão para consumir, uma fórmula básica que "ensina" a cultura do outro de forma etnocêntrica e simplista, ligada unicamente ao lazer de quem consome.

\subsection{3 - Possibilidades rumo a um turismo emancipador}

É impossível negligenciar que o fator econômico seja importante para as pequenas comunidades, visto que a geração de lucros se faz imprescindível para essas localidades, por se apresentar muitas vezes como maior, ou mesmo única, fonte de renda. 
Tentar anular a produção de lucro através do turismo nas culturas populares subalternas seria impossível, o que além de ser uma proposta inviável, não consiste na melhor maneira de fugir das formas predatórias de turismo.

O turismo não deve ser considerado uma atividade maléfica por si, a qual possui somente efeitos prejudiciais, o que deve ser considerado prejudicial são os modos como o turismo tem ganho visibilidade e instigado a ser praticado. Se praticado de forma sustentável o turismo pode ser uma atividade altamente enriquecedora, que afasta o etnocentrismo e aproxima da relativização, que emancipa.

Para se construir um turismo não predatório, e sim emancipador, o primeiro passo é que as localidades que tem o turismo como fonte de renda, estabeleçam pontos prioritários para seu bem comum, procurando manter o caráter ideológico e identitário da comunidade, bem como a conservação do meio ambiente (alvo do ecoturismo).

"A proposta de um turismo inteligente pressupõe a participação da comunidade e do poder local no sentido de promover alguns aspectos como: conhecimento e respeito ao meio natural, participação ativa das populações locais tanto no planejamento como na implementação da atividade, abertura da possibilidade de um desenvolvimento da educação dos turistas." (FERREIRA, 2005: 11-12)

É necessário que as comunidades se vejam não como produtoras de festas e produtos culturais, mas sim como possuidoras de uma cultura cotidiana, expressa no dia-adia, disposta a intercambiar elementos com os visitadores dispostos a interagir com ela.

"Dessa forma é preciso que as iniciativas de estímulo ao turismo sejam direcionadas de maneira que permitam a expressão da diversidade e da especificidade de cada comunidade, sem que essas expressões se transmutem em mercadorias confeccionadas ao gosto médio do turista." (FERREIRA, 2005: 140.)

No turismo emancipador, as localidades não vêm o turista como dominador, como prepotente e superior por ser gerador de lucro. Este é o principal fator correspondente a descaracterização e a alienação, pois nestes casos as comunidades passam a adotar a ideologia do turista para se adaptarem a ele, se tornando "sociedades dependentes, que 
adotam como visão de si mesmas a ideologia de seus dominadores, rompendo toda correspondência entre seu ser e sua consciência." (RIBEIRO, 1983: 130)

Na maioria das culturas populares subalternas exploradas pelo turismo, é necessário desconstruir, primeiramente, o turismo predatório para que se possa aos poucos, nas brechas da desconstrução, construir um turismo emancipador, onde a comunidade é composta por sujeitos-atores, e não passivos. Porém, o processo de transformação é lento, pois advém da autoconsciência identitária das próprias comunidades e não somente da intervenção de fatores externos.

Um dos fatores de extrema importância para a produção de um turismo emancipador está na produção de um turismo sustentável, de um desenvolvimento sustentável. Neste sentido é de extrema importância o entendimento do antagonismo entre o desenvolvimento econômico (que sempre tem como meta o crescimento) e sustentabilidade. É justamente aqui que se encontra a resposta para a dificuldade de se produzir sem destruir: no antagonismo.

A produção turística, por exemplo, explora diretamente o meio ambiente e as comunidades, bem como toda atividade capitalista os explora, porém de formas diferenciadas. O turismo emancipador se dá exatamente no encontro equilibrado entre desenvolvimento econômico e a sustentabilidade, caracterizado pela minimização das descaracterizações impositivas geradas pelos turistas reprodutores de modelos midiáticos, e obtenção de renda através da identidade cultural como expressão da cotidianidade, e não como espetáculo.

Como a maioria das pequenas comunidades experimenta o turismo predatório para posteriormente irem a busca de um turismo emancipador, se faz necessário conhecer a fundo todos os mecanismos ligados à indústria cultural descaracterizante e deformante, todas as formas estimuladoras de etnocentrismo, para que através deste conhecimento se faça possível abrir possibilidades emancipadoras.

Criar um turismo emancipador é conseguir fugir dos padrões impostos pelo sistema capitalista fazendo uso "responsável" de sua principal finalidade: o lucro. 


\section{4 - A arte das culturas populares subalternas como elementos de consumo durante as festas populares.}

Partindo do pressuposto que o contexto histórico e social é inseparável das manifestações populares, como no caso das festas das culturas populares subalternas, estudar o impacto da indústria cultural sobre as pequenas comunidades (separando história e sociedade), faz tornar mais palpável, também, os vários estudos teóricos realizados sobre arte, os ritos e costumes que sobrevivem ao tempo e sua relação com a comunicação na era da globalização.

Nas festas populares subalternas, além de as próprias festas acabarem representando, predatoriamente, um produto a ser consumido, um espetáculo a ser observado, o cenário das festas acaba por contribuir para outras formas de apropriação descaracterizante das culturas populares subalternas, pois através delas se monta toda uma estrutura para recepcionar o turista. É muito comum, portanto, que os espaços dedicados à venda de artesanatos aumentem ainda mais nestes períodos, com a finalidade de maximizar a lucratividade e atender a demanda dos turistas, como acontece no caso das festas de Lavras Novas.

O problema deste tipo de situação está justamente na forma predatória como o comércio de artesanatos pode se manifestar, substituindo uma produção que dialoga com a cotidianidade e os valores simbólicos da comunidade, para simplesmente servir ao gosto médio dos turistas. Segundo Ferreira: "O artesanato cumpre um papel significativo na cultura de uma sociedade. À parte seu valor material, reconhecido desde tempos memoriais, sua função cultural é integradora da sociedade que o produz". (FERREIRA, 2005: 62)

$\mathrm{O}$ artesanato, quando semi-industrializado, já transformado em mercadoria, apesar de trazer prosperidade às regiões onde é praticado, pode, ao mesmo tempo, fazer com que esta arte perca a função identitária dentro da comunidade, a que está ligada a realidade, ao significado presente do dia-a-dia.

Para Lukács a arte representa sempre o mundo dos homens. A arte revela o estágio social em que uma sociedade se encontra, reflete, de maneira dialética, o que está intrincado ao mundo dos homens e a sua realidade social. Apesar de o conceito utilizado por Lukács ser formulado a partir de outros pressupostos e para um período histórico 
diferente do que se apresenta a obra de arte das culturas populares subalternas atualmente, ele pode ser facilmente reportado (o modelo teórico) para o âmbito que pretendemos abordar em relação a este tipo de arte.

A arte das culturas populares subalternas, assim como suas diversas manifestações (nas festas populares, por exemplo) por existirem na cotidianidade, no que se representa no dia-a-dia, representa a realidade dos homens e mulheres daquela comunidade, representa suas tradições sobreviventes à cultura hegemônica. Aqui não se define o real na arte apenas como cópia fotográfica da realidade, mas sim como um reflexo, não exatamente no sentido estrito do retratar, mas sim no de apresentar-se, mesmo que de forma sobre-humana, o que permeia a vida dos homens dentro de uma realidade social e de um período histórico. Lukács afirma que:

"Já que a arte representa sempre e exclusivamente o mundo dos homens, já que em todo ato de reflexo estético (diferentemente do científico) o homem está sempre presente como elemento determinante, já que na arte o mundo extra-humano aparece apenas como elemento de mediação nas relações, ações e sentimentos dos homens, deste caráter objetivamente dialético do reflexo estético, de sua cristalização da individualidade na obra de arte, nasce uma duplicidade dialética do sujeito estético, isto é, nasce no sujeito uma contradição dialética que, por sua vez, revela também o reflexo de condições fundamentais no desenvolvimento da humanidade. Trata-se aqui da relação entre homem e humanidade. Objetivamente, esta relação sempre existiu, razão pela qual devia sempre reaparecer, de um modo ou de outro, nas formas do reflexo da realidade.” (LUKÁCS, 1968: 191)

As culturas populares subalternas, bem como sua arte, se expressando de diversas formas, tem como objetivo sempre a ligação de tal comunidade com a sua realidade ou com sua produção, ou seja, com a confecção de sua realidade atual pelas realidades anteriores. Para melhor entender-se, pode-se dizer que as comunidades representam seu passado, porque foi este que as transformou no que são no presente. Não é entender história somente como linearidade, mas sim como um processo que se direcionou, por diversos fatores, para o que tal comunidade tem como entendimento de si hoje.

Para expressar melhor a forma de representação artística do que Lukács chamou de extra-humano pode-se citar a produção de máscaras com rostos não totalmente humanos na comunidade de Lavras Novas. São máscaras que apresentam rostos deformados e coloridos, não são representações fotográficas do que são os homens daquela comunidade 
nem sua visão de si mesmos, mas sim a representação de sua realidade religiosa, a representação do incorpóreo de seus antepassados e da energia vital, apesar de não sua materialização. É deste modo que este trabalho re-interpreta o entendimento do que Lukács chamou de extra-humano, porém real, para o âmbito da arte das culturas populares subalternas. Na verdade poder-se-ia chamar, mais acertadamente, de uma amplificação do conceito para uma nova esfera, o da arte das culturas populares subalternas.

Outro aspecto importante a ser ressaltado em relação às obras de arte das culturas subalternas é em relação a seu consumo e sua apreciação remetida à realidade em que tal obra está inserida. Segundo Lukács:

"O reflexo estético cria, por um lado, reproduções da realidade nas quais o ser em-si da objetividade é transformado em um ser para-nós do mundo representado na individualidade da obra de arte; por outro lado na eficácia exercida por tais obras, desperta e se eleva a autoconsciência humana; quando o sujeito receptivo experimenta - da maneira acima referida - uma tal realidade em si, nasce nele um para si do sujeito, uma autoconsciência, a qual não está separada de maneira hostil do mundo exterior, mas antes significa uma relação mais rica e mais profunda de um modo externo concebido com riqueza e profundidade, ao homem enquanto membro da sociedade, da classe, da nação, enquanto microcosmo autoconsciente no macrocosmo do desenvolvimento da humanidade." (LUKÁCS, 1968: 201)

Mas como pode haver criação de autoconsciência quando o consumo de um determinado tipo de arte é feito fora de sua realidade sócio-cultural, ou seja, fora de onde seus valores simbólicos são entendidos e significados? Quando a obra de arte é descaracterizada simbolicamente por ser consumida fora de seu contexto perde-se a riqueza na contemplação, pois se perde o autoconhecimento através desta. A arte perde o valor simbólico para ganhar valor mercadológico, perde sua riqueza de produção e de trabalho para o valor estético de quem a compra, ou, em maior instância, para o valor estético que é ditado para quem a compra: a arte da cultura popular subalterna se transforma produto da indústria cultural, servindo à hegemonia.

O problema que se instala nas culturas populares subalternas, em suas festas, e aqui, mais precisamente, em sua arte é o consumo descontextualizado incentivado pelo mercado de turismo, à cultura das pequenas comunidades. Muitas comunidades, hoje, produzem em grande escala apenas para venda, não produzem arte como uma autoconsciência da própria comunidade, como enfatiza Lukács. O problema é que com isso muito do que essas 
comunidades tinham para si como reflexo de sua realidade passa a ser enxergado como obsoleto e como futilidade, trocando os valores simbólicos por obtenção de lucro. Desta maneira, desmancha-se a lógica de resistência ao massivo e a lógica antagônica à hegemonia das culturas populares subalternas, para agir como colaboradora à manutenção sistêmica.

Lukács afirma que “... a hostilidade à arte e à cultura, própria do sistema capitalista, comporta, ao contrário, o fracionamento da totalidade concreta em especializações abstratas." (LUKÁCS, 1968: 24). Segundo o autor "Marx e Engels jamais negaram o caráter progressista do sistema capitalista de produção, mas ao mesmo tempo, desmascaram-lhe, desapiedadamente os aspectos desumanos.” (LUKÁCS, 1968: 24).

Toma-se hostilidade, aqui, ao entendê-la como a transformação de arte em produto, não como parte de uma história possuidora de tradições. Todos os valores são substituídos pelo possuir, foi o que Marx chamou de fetichização. O sistema capitalista desumaniza, vai contra o que é o objeto da arte das culturas populares subalternas: o ser humano.

Se o sistema produz para o consumo superficial, não se espera que esse produto possa ser consumido de outra maneira dentro dos ambientes aos quais foram estes produtos destinados. Segundo Adorno:

\begin{abstract}
"A manipulação tem seus limites. Por outro lado, é preciso ter em conta que a trivialidade e a superficialidade de um material destinado de antemão a ser percebido em situações de distração não permite esperar senão relações relativamente triviais e superficiais." (ADORNO, 1995: 156).
\end{abstract}

O impasse que se cria imbricando arte popular subalterna e descontextualização pode ser remetido à conceituação de formalismo utilizada por Lukács. Apesar de o conceito ser utilizado pelo autor para contrapor arte naturalista e arte formalista, a conceituação de vazio proposta por ele pode se levar em conta por ser explicitada da mesma maneira na qual este trabalho entende o formalismo relativo à existência de objetos fora de seus ambientes de significação.

Ao mesmo tempo em que formalmente se pode descrever cores, formas, texturas dos objetos, não se pode dizer o que aquele objeto artístico tem a ver com a realidade social do ambiente em que foi. É o ter a forma como decoração, como adorno que não precisa dizer nada, que se basta pela presença e pelo visual. Não é que a forma não seja importante, 
mas sim acreditar que a importância da forma advém do lócus de origem e de seus significados de criação.

Lukács, falando da descontextualização na literatura, afirma que "As coisas só tem vida poética enquanto relacionadas com acontecimentos de destinos humanos." (LUKÁCS, 1968: 78). O contexto, portanto, é indispensável para a captura de uma significação nãodeformadora.

Brecht também pode ser citado para aprimorar a conceituação em relação ao que foi falado sobre formalismo dentro da arte popular subalterna. Apesar de uma leitura um pouco diferente da de Lukács e de suas muitas divergências teóricas, Brecht contribui com muitos elementos em relação à análise da arte formalista que podem convergir com o que esta pesquisa tomou dos conceitos de Lukács para abordar de uma maneira, relativamente nova, a arte popular subalterna.

Brecht coloca pontos importantes que podem ser reportados (não-anacronicamente, mas considerando as mudanças sócio-culturais de contextos) ao que se pretende apontar como consumo formalista da arte, e as duas conceituações não se contradizem em nenhum aspecto, somente se transformam devido ao campo que pretendem abarcar, assim como já foi utilizado neste artigo o conceito proposto por Lukács. Brecht afirma que "Se queremos falar para o povo, temos que ser entendidos pelo povo. Mas também isto não é uma simples questão de forma.” (BRECHT, 1968: 240).

Nesta afirmação Brecht se reporta a forma de dirigir a arte ao povo em um contexto socialista, diferente do contexto atual em que se enquadra a arte popular subalterna, porém, o falar ao povo, para ele, é estar em seu contexto, é falar dele para quem está nele de maneira que a forma e o conteúdo sejam complementares. Para se entender um contexto ou explicá-lo devemos estar inseridos nele. O mesmo acontece com a arte.

Não que as culturas populares subalternas não possam ser entendidas e conhecidas por indivíduos que fazem parte de outros modos de vida, mas enfatiza-se aqui o jeito como o consumo dos objetos das culturas populares subalternas, sua arte e suas manifestações são incentivadas a serem entendidas deformadamente e simplificadamente pelas maneiras superficiais e pontuais em que os meios de comunicação de massa as colocam.

A situação incitada há algum tempo pela indústria cultural do turismo vem agravando a questão da arte dentro das pequenas comunidades, tanto que podemos perceber 
a transformação de comunidades e de pontos turísticos, assim como bens imateriais das artes subalternas, em lugares autônomos, e expostos para consumo sem nenhum rosto social, como não pertencente a nenhum espaço possuído e produzido por pessoas. Os objetos vêm prontos sozinhos, sem rosto, dilui-se o sentido dialético da produção dos bens culturais de uma comunidade.

Podemos tomar como exemplo a propaganda de incentivo ao turismo que foi ao ar, pelo Ministério do Turismo, no início do ano de 2009. A propaganda tinha como tema "Tá na hora de conhecer o Brasil". Era uma propaganda de incentivo do governo para a geração de renda. Porém a forma como as comunidades a serem visitadas eram apresentadas por esta propaganda incentivava, mesmo que inconscientemente, o turismo predatório e a descaracterização cultural. Na maioria dessas propagandas se mostravam pontos turísticos vazios, inabitados. Artesanatos indígenas eram apresentados como lembrancinhas para se levar para casa, e apenas isso.

O Ministério do Turismo lançou, já no final de 2009, outra versão desta mesma propaganda. A propaganda, que ainda está no ar, consiste em mostrar alguma beleza natural ou algum monumento ou construção histórica e dar algumas opções para que o telespectador adivinhe o local onde se encontra tal imagem exposta. É interessante observar que em nenhuma das imagens existem pessoas da comunidade, apenas em uma delas aparece uma família de turistas fotografando uma Igreja de Ouro Preto. A idéia de locais autônomos, que será discutida no próximo capítulo, se faz presente perfeitamente neste exemplo. A criação de lugares autônomos facilita a venda dos produtos artísticos sem maiores questionamentos, pois, subconscientemente, o que a indústria cultural vem vendendo são produtos de ninguém, coisas do local, não do povo do local. Suprime-se sempre a palavra povo. É a constante desumanização do sistema capitalista.

\section{5 - Festas populares subalternas, mídia e turismo: A criação da imagem de lugares autônomos.}

Desde o aparecimento das primeiras viagens organizadas, em meados do século XIX - o chamado Grand Tour - Segundo a Organização Mundial de Turismo (OMT), “o número de turistas no mundo, passou de 150 milhões de viajantes em 1995, para 500 
milhões em 2008". ${ }^{54}$ O investimento em turismo tem triplicado a cada ano. Todos os dias são descobertos novos roteiros com a finalidade de atender aos mais diversificados gostos, e a mídia é responsável por propagá-los.

É a mídia quem dita o que é moda e o que não é moda, o que está em alta e o que não está em alta, sempre direcionando suas constatações para diversos tipos de público, produzindo padrões direcionados a cada classe social da forma como mais lhe será lucrativo em termos de consumo, mercado ou geração de renda (como é o caso das propagandas de incentivo ao turismo feitas pelo Estado, citadas no tópico anterior).

Este fenômeno de direcionamento de padrões e gostos não é uma iniciativa nova, mas sim, somente, uma iniciativa que pode ser observada mais claramente nos últimos anos. Prestar atenção ao direcionamento específico de produtos a classes sociais pode fazer com que se perceba um impacto às vezes deixado de lado e pouco analisado em relação às culturas populares subalternas.

Isso pode acontecer, principalmente, por tentar-se, na maioria das vezes, incluir todos os fenômenos relacionados à reificação considerando somente a abordagem teórica proposta pela teoria da Escola de Frankfurt, a teoria da indústria cultural (não desconsiderando esta). Dessa forma faz-se uma análise rasa e limitada, pois, apesar de muito do que se trabalha em relação à transformação de bens culturais em produtos mercadológicos ter tido sua base na teoria frankfurtiana, esta se torna insuficiente para uma análise eficiente das relações entre mercado e cultura na atualidade.

Hoje os produtos e os serviços são produzidos especialmente para cada tipo de consumidor, considerando sua necessidade e sua classe social. A propaganda, principal aliada do mercado, cria maneiras de atingir uma classe específica, não deixando isso explícito em sua mensagem. Isso acontece somente por se acreditar na diferença de consumo entre classes, por se saber que certos tipos de serviços ou produtos seriam somente possíveis para determinados tipos de consumidores.

No caso do turismo, esta divisão de público se torna facilmente visível, pois o mercado turístico não busca atingir as classes de baixo poder aquisitivo, para elas este seria um serviço supérfluo ou mesmo praticado raramente. É a questão proposta por Bourdieu (1983), da relação entre luxo e necessidade. O que se torna uma necessidade para as classes

\footnotetext{
54 OMT (2010) Disponível em: http//:www.world-turism.org. Acesso em 25 de maio de 2010.
} 
de alto poder aquisitivo (classes que se procura atingir, na maioria das vezes, pelas propagandas e programas de turismo) pode parecer luxo para as classes mais pobres. Pierre Bourdieu exemplifica a distinção entre as classes:

"Onde as classes populares reduzidas aos bens e as virtudes e primeira necessidade reivindicam a limpeza e a comodidade, as classes médias já mais liberadas das urgências, deseja um interior quente, íntimo e confortável ou cuidado, ou um vestuário na moda e original. Por serem já muito arraigados esses valores lhe parecem como que naturais, evidentes e são relegados ao segundo plano pelas classes privilegiadas." (BOURDIEU, 1983: 43).

O autor afirma ainda que:

"A cada nível de distribuição, o que é raro e constitui um luxo inacessível ou uma fantasia absurda para os ocupantes no nível anterior ou inferior, torna-se banal ou comum, e se encontra relegado a ordem do necessário, do evidente, pelo aparecimento de novos consumos, mais raros e, portanto mais distintivos." (BOURDIEU, 1983: 132).

Considerando as afirmações feitas por Bourdieu pode-se perceber como, de acordo com as idéias do autor, as classes sociais primam por bens e serviços de forma que sua posição social esteja em destaque, que sua posição seja diferencial em relação à classe social inferior. Isto não acontece somente com produtos materiais, mas também e principalmente no consumo de serviços que enfatizam ainda mais os gostos específicos de uma classe. Dentro destes serviços o turismo toma lugar de destaque dentro das classes sociais mais abastadas, pois é uma forma de diferenciá-las de outras classes em que o turismo é considerado como um luxo. O direcionamento de público é facilmente percebido nas propagandas de turismo, que procuram embutir sempre um diferencial atrativo a uma determinada classe ou grupo. É importante destacar também que dentro das classes que praticam o turismo há distinções entre as com maior ou menor poder aquisitivo. Diferenciam-se pelos roteiros, formas de consumo de serviços e destinos escolhidos.

Apesar de as diferenciações no consumo turístico, e das diferentes formas como o serviço pode ser oferecido, os novos destinos escolhidos têm sido, principalmente, as pequenas comunidades e, indiretamente, suas festas populares. Neste trabalho, não serão atentadas, especificamente, para as distinções na formas de consumo das culturas populares 
subalternas por cada classe social, mas sim à tomada das festas populares subalternas como produto mercadológico consumível e um bem exposto para compra em programas midiáticos, reportagens e propagandas.

Em comunidades onde o turismo vem se transformando em principal fonte de renda, é necessário observar às transformações ocorridas nas festas populares subalternas, e tê-las como uma espécie de termômetro para a percepção de como acontecem as modificações na estrutura festiva de uma localidade e suas repercussões em sua identidade sócio-cultural.

Para isso, é necessário anteriormente procurar-se entender a forma como se cria uma padronização nas formas de consumo turísticas através da mídia. Como se cria uma massa de turistas com interesses padronizados e que têm, mesmo que inconscientemente, seu interesse direcionado para um padrão de consumo mercadológico que cria uma realidade falsa de lugares autônomos, lugares que independem de seus sujeitos culturais, de monumentos e construções que se separam da história do povo local e de festas populares que parecem existir somente como espetáculo e não como parte da história de um povo, como manifestação que dá sentido às tradições.

Em relação à transformação das manifestações populares em performances, MartínBarbero afirma que o surgimento do mercado (consideramos aqui também o mercado turístico) deu origem aos processos de "enculturação: a transformação do sentido de tempo que, abolindo o cíclico, impõe o linear, centrado sobre a produção, a transformação do saber e seus modos de transmissão..." (MARTÍN-BARBERO, 1997: 131)

A criação de uma falsa realidade se encontra no colocar aa festas em um palanque para serem observadas, na perda do sentido original da manifestação, no espetáculo por si só, que não tem mais o que relembrar.

Pode-se dizer que a mídia obtém sucesso em sua padronização pela propaganda e programas de turismo devido à habituação constante dos espectadores, a qual se cria a longo prazo. Não é uma habituação no sentido de não prestar mais atenção a um estímulo, mas sim no sentido de absorção, de já não oferecer nenhuma resistência àquele tipo de imagem ou instigação. Criada esta habituação, a desabituação vem de forma a despertar a atenção. O despertar de atenção a fim de repetir um conteúdo já absorvido, só que de maneira diferente. É chamar a atenção do consumidor de turismo, com os valores 
anteriormente aceitos por ele, mas de uma forma nova que instigue a atenção novamente. Sternberg, discorrendo sobre o fenômeno da habituação, afirma que:

\begin{abstract}
"Na habituação, à medida que nos tornamos acostumados a um estímulo, gradualmente o observamos - e lhe prestamos atenção cada - cada vez menos. A contrapartida da habituação é a desabituação, na qual uma mudança (às vezes até uma mudança muito leve) em um estímulo familiar leva-nos a começar a observar novamente esse estímulo." (STERNBERG, 2000: 86)
\end{abstract}

Com a propaganda de turismo direcionada especificamente a uma classe social, em alguma revista especializada, por exemplo, a desabituação às inúmeras propagandas de turismo pode ocorrer de forma satisfatória apelando-se para elementos típicos de consumo da classe consumidora de tal revista, é o buscar a atenção seletiva do consumidor. É o manter a ideologia antiga de uma maneira diferente, que desperte interesse novo.

Segundo Sternberg "Estamos constantemente fazendo escolhas com relação aos estímulos aos quais prestamos atenção e aos estímulos que ignoramos." (STERNBERG, 2000: 82). Considerando o que diz o autor, pode-se notar que a propaganda de turismo se alimenta das novidades direcionais às classes sociais e público alvo a que quer atingir, porém, essas novidades se limitam às novas modas em turismo, a novos destinos, a relacionar o turismo de aventura com saúde e jovialidade, por exemplo; mas as novidades aparecem sempre dentro das mesmas estruturas: deformando a realidade das culturas populares subalternas. É encaixar as novidades dentro de um modelo, de um padrão que se vende autônomo, que possui lugares inabitados e com comunidades (culturalmente) "fantasmas".

O associar o turismo de aventura com saúde, esportes e virilidade é uma das estratégias de venda recentes do mercado turístico. Já as festas populares subalternas, por sua vez, vêm sendo associadas a conhecimento, cultura. É bonito ver uma manifestação cultural, é uma forma de conseguir status, de se mostrar culto. Porém, em grande parte das vezes a superficialidade no contato deforma e transforma o que poderia ser uma fonte de conhecimento e de descoberta em um produto descartável. $\mathrm{O}$ atribuir valor de troca a uma festa popular, mesmo que indiretamente, dessignifica ao simplificar. É uma perda para ambos os lados. 
A mídia, não só com suas propagandas diretas, mas também com suas "propagandas" feitas durante programas de reportagem na televisão, em revistas especializadas e em jornais, segundo Barreto (2003), cria uma separação inexistente entre patrimônio material e imaterial, pois o patrimônio deve ser percebido como um conjunto entre todos os bens de uma comunidade, não fazendo sentido um sem o outro.

O turismo de vitrines vende somente cartões postais, sempre inabitados, onde se reconhece somente o legado material. As poucas vezes em que se apela para os bens que seriam imateriais é de forma alienante e etnocêntrica, onde o exótico predomina como característica principal do produto para a venda de um conhecimento deturpado.

Lavras-Novas é uma das comunidades que vem sofrendo com o incentivo turístico deformador da mídia, como exemplo pode-se citar a reportagem veiculada no jornal Hoje em Dia, de Belo Horizonte "Lavras Novas atrai pelo frio e pelas belas pousadas" ${ }^{55}$. Na reportagem os motivos do incentivo ao turismo caem sempre no mesmo modelo de consumo e lazer: belas paisagens, trilhas maravilhosas, cachoeiras, belas pousadas e comida, a comunidade é vista como paisagem morta, à espera do turista, e não como um povoado vivo, que possui uma tradição.

Em outra reportagem do mesmo jornal "Apreciadores de vinho invadem Lavras Novas" ${ }^{56}$ a comunidade é apenas citada como palco de um evento que em nada condiz com a cultura local. Apesar disso, o evento, organizado pelos donos das grandes pousadas, é valorizado pelo jornal, que inclusive passa informações falsas sobre a comunidade, insinuando que a comunidade foi formada por negros fugidos (fato explicado no primeiro capítulo deste trabalho). A reportagem exalta a grande quantidade de turistas que chegarão à cidade (5 mil) e a superlotação das pousadas, não se preocupando, em nenhum momento com a capacidade territorial da comunidade. Os moradores da comunidade são praticamente inexistentes na reportagem, que exalta os shows com Lô Borges e a presença do ministro do turismo. É como se a comunidade, o espaço identitário, se transformasse em um local vazio, inabitado, que pode ser ocupado com se bem entender.

A idéia de locais autônomos se faz presente, perfeitamente, no exemplo citado acima. São formas muitas vezes inconscientes que fazem com que se crie uma

\footnotetext{
55 Vide anexo 1.

56 Vide anexo 2.
} 
descaracterização na identidade cultural da região, pois não só os turistas passam a procurar somente os produtos que lhes são oferecidos, mas também os sujeitos que habitam em tais comunidades e possuem suas tradições, festas, costumes, passam a entender, muitas vezes, que suas manifestações culturais têm apenas valor como produto a ser vendido para a observação de turistas, e não como um importante alicerce para seu entendimento enquanto grupo sócio-cultural.

É com a criação de lugares aparentemente autônomos e de comunidades que existem simplesmente como manifestações festivas pontuais, desaparecendo posteriormente, que a mídia com seus programas, reportagens e propagandas propriamente ditas, reifica localidades e mesmo comunidades de forma a oferecê-las dentro de um falso conhecimento.

A propaganda autonomiza para vender e normaliza a construção de manifestações populares para a venda dentro das comunidades. Acaba que o turista, que consome de acordo com o proposto pela mídia, consome uma realidade criada, inexistente, uma comunidade desabitada, dentro de um padrão funcionalista, de acordo com as regras do mercado de turismo.

Para uma análise dos mecanismos da propaganda, pode-se citar a teoria do cultivo ou da incubação, proposta inicialmente por Gerbner, Gross, Morgan e Signorelli. De acordo com Sousa:

“... a presença de determinados temas e mensagens no conteúdo dos media pode gerar a incubação de idéias dissonantes da realidade, sendo o grau de desvio dessas idéias tanto maior quanto maior for a dissonância existente entre a realidade e as suas representações mediáticas. A teoria evoluiu, desta forma, para uma proposta de explicação da acção dos meios de comunicação sobre a sociedade..."'(SOUSA, 2006: 522).

Conforme tal teoria, os meios de comunicação tem a finalidade de moldar uma sociedade de acordo com que é proposto por seus conteúdos, de criarem uma estrutura que se adeque ao estágio de desenvolvimento industrial e, dentre outras funções, produzirem gostos e preferências. A teoria do cultivo é uma teoria que perspectiva os efeitos da comunicação social a longo prazo. Para Gerbner (1977), a influência dos meios de comunicação social é acumulativa. 
É no sentido de criação de uma realidade fantasiosa e da criação de gostos e costumes que esta teoria se faz consoante com o que esta pesquisa propõe em relação aos usos feitos pela mídia, juntamente com a indústria de turismo, das imagens das comunidades e suas manifestações. É a criação, em longo prazo, de uma forma predatória de turismo, que se preocupa em criar propagandas com cartões postais que instiguem uma visita para simples apreciação de paisagens, não procurando compreender, ou mesmo deixando passar despercebido, o dinamismo cultural das comunidades.

Pode-se considerar que o deixar passar despercebido acontece devido à percepção seletiva: vemos aquilo que procuramos ver. E, neste caso, procuramos ver aquilo que somos instigados e "moldados" para desejar ver. Segundo Souza "O ser humano tende a perceber bem unicamente aquilo que deseja perceber bem.” (SOUSA, 2006: 30.)

A Teoria do Cultivo vai além da teoria do Agenda-Setting, proposta por McCombs e Shaw em 1972, pois, acredita que os meios de comunicação não apenas agendam sobre o que pensar (como propõe a teoria do Agenda-Setting), mas também como pensar e o que desejar. Neste caso a teoria do Agenda-Setting pode ser citada como forma complementar a Teoria do Cultivo, no sentido de que o consumidor e instigado a viajar, a consumir turismo e pensar sobre turismo. Este trabalho somente discorda de que o fato de a mídia dar opções de destinos para viagens, por exemplo, e a possibilidade de o consumidor escolher um deles, não ser uma forma de moldar os desejos deste consumidor, mesmo perante alternativas.

O que determina o caráter criador de falsa realidade pela propaganda e pela mídia é justamente o padrão de como consumir turismo e não somente o consumir turismo. A descaracterização não é feita pelo consumo, mas sim pela maneira como o consumo é feito. E a maneira como o consumo é feito está diretamente ligada à forma como ele é instigado a ser feito, pela padronização de desejos proposta pelo mercado capitalista e pela ancoragem destes preceitos na mídia em seus mais diversos formatos.

Não se acredita que os meios de comunicação possuam um poder ilimitado sobre as pessoas, mas um poder limitado, que em muitos casos, e principalmente a longo prazo, têm capacidade de moldar desejos e padrões.

É importante salientar que as pessoas possuem mecanismos de defesa contra a persuasão, mas estes mecanismos são acionados somente quando o que o indivíduo acredita 
de antemão é contrariado. ${ }^{57}$ No caso da propaganda em turismo, por exemplo, a questão da percepção seletiva vai funcionar a favor do conteúdo da propaganda, na maioria das vezes, visto que, se usam posições massivas que tendem a ir de encontro aos desejos e aspirações dos espectadores deste tipo de produto. Por que se pode julgar que tais posições seriam massivas? Porque a propaganda se apóia em uma realidade criada pela mídia, em padrões já arraigados na sociedade. Faz-se propaganda em turismo para uma sociedade que acredita nos valores ratificados pela mídia, uma sociedade que foi modelada para o consumo, com gostos e desejos pré-fabricados hegemonicamente e com algumas alternativas para diferenciação de classes e grupos.

É de acordo com estas afirmações que se desconsidera a exposição seletiva e os mecanismos de defesa contra a persuasão dentro da propaganda em turismo. O turismo é sempre visto como uma atividade prazerosa, e que possui alternativas para atender aos mais diversos tipos de público.

Todavia, o objetivo deste trabalho não é apenas reafirmar o poder de persuasão da mídia sobre a sociedade, e nem de mostrar uma superfície imutável, mas sim de entender a forma como a propaganda aplica seus mecanismos, fazendo com que se crie uma esfera aparentemente real, que poucos pensam em questionar, justamente por se apresentar tão comum em nosso dia-a-dia.

\section{6 - A oralidade como frente de resistência ao hegemônico no contexto das culturas populares subalternas}

A cultura oral desempenha um papel fundamental nas festas populares subalternas, pois está presente na constituição da identidade sócio-cultural das culturas populares, como no caso de Lavras Novas. A oralidade presente na formação dessas culturas se manifesta, (quando não transformada em mercadoria), em desafiante aos modos impostos sistemicamente, constituindo um locus de resistência ao hegemônico.

Considerar a oralidade como um locus de resistência é também enxergá-la como palco de constantes conflitos. É vê-la como uma portadora de conteúdos que são alvos sucessivos de tentativas de expurgação pela lógica de consumo, seja através da deformação,

\footnotetext{
${ }^{57}$ SOUSA, J. P. Elementos de teoria e pesquisa da comunicação e dos media. 2ed. Editora Porto, 2006.
} 
deslocamento de sua essência ou mesmo através do descarte. Lógica esta que, aos poucos, tenta embutir dentro das próprias culturas orais, a negação de sua tradição, relegando-a a inutilidade. Torna-se possível, a partir destes pressupostos, entender um fenômeno relativamente novo no universo das culturas populares subalternas, que é a criação de um sistema de autodesvalorização cultural em muitas comunidades.

Muitas vezes as formas de englobamento da oralidade pelo puramente mercadológico se dão através de uma tecnologização da palavra. Procura-se entender a valorização constante da escrita em detrimento da palavra falada como uma forma impositiva às pequenas comunidades, dada pela indústria em parceria com a mídia, que ao estabelecer um sistema de referências erudito desvaloriza o que não lhe é próprio. Com a exclusão da tradição oral, passa-se a excluir da história não somente o componente subjetivo, mas também uma reflexão sobre o mundo popular como ator indispensável em sua construção.

Assim, torna-se imprescindível entender a história oral ${ }^{58}$ de forma dialética, pois a cultura oral, ao mesmo tempo em que é pano de fundo para todo o tipo de manifestação popular, é modificada o tempo todo por elas. O mecanismo hegemônico de mercado age justamente neste sentido, sendo retórico e quebrando este ciclo dialético. Este mecanismo consiste na construção de manifestações acabadas, que não mais se edificam através da produção subjetiva de um povo, mas sim em uma lógica que se encaixa a um modelo de expressão oral que relega os causos, as rodas de conversa e viola, os mitos e as lendas ao universo dos pacotes prontos e das vitrines consumitivas.

O que passa a ter valor, de acordo com a indústria cultural, são apenas fragmentos das culturas populares que podem ser capturados e nomeados como produtos. A lógica dialética e construtiva da história oral para com sua comunidade, por não possuir captura fragmentária, muitas vezes é relegada à inutilidade.

Com a criação de uma separação inexistente entre patrimônio material e imaterial, separa-se lugar, de festa popular, de arte, e de história oral. Cria-se uma separação facilitadora ao mercado. A venda passa a acontecer por setores e estes setores já se encontram arraigados na percepção de possíveis consumidores, através da mídia (mesmo que inconscientemente).

\footnotetext{
${ }^{58}$ A definição e história oral utilizada neste trabalho não remete ao método de história oral utilizado pelos Anais Franceses.
} 
Através da fragmentação dilui-se a memória coletiva de uma comunidade em setores que não podem explicitar-se sozinhos. Assim, a oralidade é relegada ao fantástico.

Ao falar-se em mitos, lendas e causos que povoam o imaginário popular, por exemplo, é importante estabelecer um percurso fundamentado em conceitos intrínsecos como memória coletiva, oralidade e comunidade; para melhor compreender este universo, é imprescindível entendê-los juntos. De forma fragmentada eles perdem o sentido, caem dentro dos ciclos propostos hegemonicamente.

Para entender-se o conceito de comunidade admitido neste trabalho, considera-se a explicação de acordo com algumas configurações que o mesmo tem assumido, não somente no sentido de território, mas através de outros tópicos que estão presentes nas comunidades atuais. Ao tratar-se do termo comunidade, a utilização do mesmo se dá no sentido de instrumento cultural, com significação transformadora, e não apenas como conceito sociológico (estrutura social). Neste sentido, é assimilada uma abordagem do conceito de Bachelard (1966), em que o autor trabalha na constituição de um "arquétipo de longa duração", constante no imaginário social, presente em tempos históricos diferentes. Considera-se ainda, o poder de resgate da solidariedade, não no sentido da ética humanista ou positivista, mas como estratégia na construção de um saber particular que provenha da experiência local.

Raquel Paiva (1988), ao falar de comunidade, explicita a necessidade de analisar que tipos de bens o grupo compartilha, e inclui como principal partilha a linguagem. Assim, discorrer sobre o conceito de comunidade requer que reflitamos, como sugere Paiva (1998), sobre a linguagem, que em pequenas comunidades, manifesta-se na cultura popular subalterna.

A oralidade primária, segundo Pierre Lévy (1994), remete ao papel da palavra antes que uma sociedade tenha adotado a palavra escrita. Em muitas culturas populares, apesar de as comunidades terem sido alfabetizadas com o passar do tempo, a formação de sua memória foi edificada e transformada através, principalmente, da palavra falada. A existência da escrita e da alfabetização não faz com que a cultura oral perca sua importância para a formação e perpetuação da identidade sócio-cultural de uma população. É o que acontece no distrito de Lavras Novas: a população foi alfabetizada com o tempo, porém a base identitária da comunidade se dá na oralidade primária, com a perpetuação de 
mitos, lendas e causos que se tornaram parte da memória coletiva da população. Pierre Lévy, ao discorrer sobre oralidade primária, afirma que:

\begin{abstract}
"Na oralidade primária, a oralidade tem como função básica a gestão da memória social, e não apenas a livre expressão das pessoas, ou a comunicação prática cotidiana (...). Numa sociedade oral primária quase todo edifício cultural está fundado sobre as lembranças dos indivíduos. A inteligência, nestas sociedades, encontra-se muitas vezes identificada com a memória, sobretudo com a auditiva." (LÉVY, 1994: 77).
\end{abstract}

Para falar sobre oralidade primária, Pierre Lévy a compara com a oralidade secundária, que, para ele existe em sociedades que têm a escrita como legitimadora da história.

\footnotetext{
“A persistência da oralidade primária nas sociedades modernas não se deve tanto ao fato de que ainda falemos (o que pode estar relacionado à oralidade secundária), mas à forma pela qual as representações e as maneiras de ser continuam a transmitir-se independentemente dos circuitos da escrita e dos meios de comunicação eletrônicos" (LÉVY, 1994: 84).
}

Considerando a formação de culturas populares subalternas através da oralidade primária, em que a inteligência encontra-se identificada com a memória, Halbwachs, nos anos 1920-30, já havia preconizado que a memória deve ser entendida também, ou, sobretudo, "como um fenômeno coletivo e social, ou seja, como um fenômeno construído coletivamente e submetido a flutuações, transformações, mudanças constantes". (HALBWACHS, 1990: 29)

A questão central na obra de Maurice Halbwachs (1990) consiste na afirmação de que a memória individual existe sempre a partir de uma memória coletiva, posto que todas as lembranças são constituídas no interior de um grupo. A origem de várias idéias, reflexões, sentimentos, paixões que atribuímos a nós, são, na verdade, inspiradas pelo grupo. A disposição de Halbwachs acerca da memória individual refere-se à existência de uma "intuição sensível”.

Para ele, a memória individual, é construída a partir das referências e lembranças próprias do grupo, refere-se, portanto, a um ponto de vista sobre a memória coletiva. Olhar este, que deve sempre ser analisado considerando-se o lugar ocupado pelo sujeito no interior do grupo e das relações mantidas com outros meios. 
A lembrança, de acordo com Halbwachs, "é uma imagem engajada em outras imagens" (HALBWACHS, 1990: 55). Para ele, lembrança está muito mais dentro do universo de significação do individual através do grupo no qual está inserido, do que na realidade histórica. Para além da formação da memória, Halbwachs aponta que:

"As lembranças podem, a partir desta vivência em grupo, ser reconstruídas ou simuladas. Podemos criar representações do passado apoiadas na percepção de outras pessoas, no que imaginamos ter acontecido ou pela internalização de representações de uma memória histórica, que não necessariamente necessita ser factual." (HALBWACHS, 1990: 34)

Neste sentido pode-se apontar a questão dos mitos e lendas como grandes aparatos na criação da memória, sendo que os mitos estão muito além do imaginário popular, pois constituem uma realidade antropológica fundamental. Partindo deste pressuposto, relegar a cultura oral de uma comunidade, de um povo, à inutilidade, é destruir sua identidade no que diz respeito a sua memória coletiva, é destruir o sentido de pertencimento do indivíduo às suas tradições.

Everardo Rocha, ao discorrer sobre mitos, considera que o trabalho dos antropólogos tem por finalidade interpretar o mito para descobrir o que este pode revelar sobre as sociedades:

"É a interpretação do mito como forma de compreender uma determinada estrutura social. Nesta linha, a antropologia usualmente assume a existência de uma relação entre o mito e o contexto social. O mito é, pois capaz de revelar o pensamento de uma sociedade, a sua concepção de existência e das relações que os homens devem manter entre si e com o mundo que os cerca" (ROCHA,1990: 83).

Assim, tanto os mitos quanto as lendas presentes nas culturas populares subalternas, que foram transmitidos através da cultura oral, e que são de suma importância para a explicação e sentimento de pertencimento de um povo a sua cultura, podem vir a representar um locus de resistência à lógica de mercado quando não se atêm à produção no sentido unicamente lucrativo.

Na comunidade de Lavras Novas são muitos os mitos e lendas que permeiam o imaginário popular, dentre eles podemos citar a lenda da mãe do ouro, a lenda de Lina e Daniel, do cavaleiro da meia-noite, etc. Porém estes se encontram muito mais presentes na 
memória da população mais idosa do distrito. É como se as novas gerações se imbricassem no sistema hegemônico, valorizando as manifestações populares e a identidade cultural da comunidade somente no sentido em que podem ser lucrativas, desconsiderando o que não é instigado a ser valorizado pela lógica midiática. A descaracterização, neste caso, não provém, diretamente dos turistas que freqüentam a comunidade, mas sim de mecanismos massificadores da sociedade, representados através da mídia, da escola, etc.

Em Lavras Novas a história oral ainda é valorizada enquanto objeto de interação social, perante todos os mecanismos hegemônicos de abrangência mercadológica, porém, apesar de não sofrer a deformação referente à transformação em mercadoria (como acontece em alguns aspectos das festas populares e nos artesanatos, por exemplo), vem sendo relegada à inutilidade, justamente por não se enquadrar nas demandas constantes do mercado de turismo.

É somente entendendo os mecanismos complexos de funcionamento da sociedade e enxergando as constantes transformações da base e da superestrutura social, entendendo seu processo dinâmico e a forma como a indústria cultural vem se organizando juntamente com a mídia, que se tornará mais fácil entender a situação em que se encontram as culturas populares subalternas hoje: uma posição aparentemente de destaque, mas de maneira deformada, tendo valorizadas a estética e as coreografias ensaiadas e não o valor simbólico tradicional que dão o sentido de existência a uma identidade verdadeiramente popular, que se expressa na cotidianidade. Somente a partir do entendimento das deformações, e da forma como essas deformações acontecem em seu constante dialogismo com a base, se tornará palpável uma transformação social real, não superficial. 


\section{CAPÍTULO III}

\section{AS FESTAS POPULARES DE LAVRAS NOVAS: ENTRE OS SANTOS E AS}

\section{ALMAS.}

Neste capítulo será feita uma análise de duas das festas populares subalternas de Lavras Novas (Festa do Divino e de Nossa Senhora dos Prazeres e ritual de Encomendação das Almas, que acontece nas festividades de Semana Santa), da forma como sua cultura e sua identidade sócio-cultural tem respondido aos intermitentes estímulos midiáticos e ao aumento constante do turismo nos últimos anos, para isso, considerando sempre os padrões hegemônicos estimulados pelos meios de comunicação de massa como instigadores da produção de turismo predatório.

Cada uma das festas populares da comunidade de Lavras Novas foi analisada de modo a serem consideradas todas as variáveis às quais estão expostas as festas populares subalternas: ao mesmo tempo em que constituem um locus de resistência ao massivo, estão expostas às massificações incentivadas pela mídia e seu apelo predatório e, além disso, sujeitas a ressignificações inerentes a seu caráter dinâmico, caráter este existente em toda manifestação cultural.

Considerando que essas variáveis podem coexistir no universo popular, é indispensável pesquisar a relação entre as festas populares e a cotidianidade da comunidade e para isso a pesquisa de campo se desenvolve de modo a fazer uso da história oral contada pelos moradores da comunidade, e a partir da vivência e observação de cada peculiaridade encontrada na comunidade de Lavras Novas.

A voz dos moradores da comunidade, símbolo da resistência presente na perpetuação da oralidade na localidade se faz indispensável à edificação deste trabalho, pois através dela é possível conhecer as mudanças ocorridas na comunidade nos últimos anos, as influências dos veículos de comunicação de massa na estrutura social da comunidade, e também as transformações decorrentes do aumento abrupto do turismo na região. Segundo Freire:

A história oral pode constituir uma excelente técnica para se afetar um primeiro levantamento de questões, sobretudo em áreas e localidades ainda pouco exploradas, onde os dados são escassos ou inexistentes. Isso quer dizer que é útil para o preenchimento de lacunas havidas nos documentos 
escritos, ou para registrar o que ainda não se cristalizou nesses documentos. (FREIRE, 2002: p.123)

Através dos depoimentos dos moradores do distrito e do estudo sobre as manifestações sincréticas brasileiras, onde sagrado e profano se unem para formar as festas religiosas que surgem ainda no Brasil colônia, e ainda com a análise de documentos históricos relacionados à formação de Minas Gerais e da comunidade de Lavras Novas, esta pesquisa procura estudar cada uma destas festas populares, de maneira a possibilitar a identificação de possíveis elementos predatórios e emancipadores, para que a partir desta análise seja possível propor melhorias que implementem e estimulem o turismo emancipador, procurando extirpar características próprias do turismo predatório.

\section{1 - O sagrado e o profano como raiz da festa brasileira}

Para analisarem-se as duas festas de Lavras Novas que são objeto de estudo desta pesquisa faz-se imprescindível remeter-se à formação religiosa do país como um todo, e posteriormente a formação afro-católica do Estado de Minas Gerais, para que as peculiaridades das tradições de Lavras Novas possam ser estudadas e analisadas separadamente.

Considerando a afirmação de Ferreira (2005), de que a identidade cultural de um povo advém, primeiramente, da formação de sua identidade nacional, estudar as formas sagradas e profanas que criaram a religiosidade sincrética do Brasil facilita várias explicações sobre as festas das culturas populares subalternas de Lavras Novas.

Pode-se afirmar que a miscigenação cultural no Brasil, envolvendo elementos católicos e profanos ocorreu logo no início da colonização: primeiramente no contato do português com o índio e, posteriormente, no contato com os negros escravizados.

As culturas indígena e negra, tiveram seus cultos reprimidos e a religião católica como imposição. Afinal, não há uma forma mais eficaz de dominação do que a dominação cultural, com ela retira-se de um povo sua identidade, suas concretudes, seu sentido de pertencimento a um grupo, deixando-o sem bases sólidas em que possa se apoiar, tornandoo vulnerável a todo tipo imposição. 


\begin{abstract}
"Quando se deu a colonização na América Latina por parte dos portugueses e espanhóis, eles usaram a religião cristã como forma de dominação dos povos nativos. Uma vez convertidos à fé católica, era mais fácil torná-los submissos, tentando apagar os costumes e crenças, desarticulando-os do sistema anterior. Quando trouxeram os negros utilizaram a mesma forma de dominação." (WATANABE, 2005: 87)
\end{abstract}

Na primeira metade do século XVI, com a chegada do primeiro grupo de africanos escravos ao Brasil, para trabalharem nos engenhos de açúcar, aumentou-se a miscigenação cultural (a qual ocorria, ate então, somente entre brancos e índios), promovendo a mistura entre elementos católicos e africanos, surgindo daí as formas mais notáveis de sincretismo religioso.

Em Minas Gerais, o primeiro contingente de escravos negros chegou no início do século XVIII, levados para trabalhar nas minas de ouro descobertas na região. A partir daí os escravos foram levados para as demais regiões mineradoras, como a região de Itatiaia, que abrangia, dentre vários outros, o distrito de Lavras Novas.

A partir do estudo da maioria das regiões mineradoras de Minas Gerais, constata-se a existência de expressivos conjuntos de manifestações da cultura religiosa brasileira que têm sua origem na época da colônia. Estas manifestações culturais, apesar de advindas, em sua essência, da colonização portuguesa, acabaram por se misturar com elementos da cultura africana, criando manifestações religiosas afro-católicas, que unem o sagrado ao profano. Os elementos oriundos dos cultos religiosos indígenas não são muito comuns nas festas mineiras, onde a influência negra foi muito forte, porém ela ocorre de forma mais aparente em outras regiões brasileiras.

Como foi discutido no primeiro capítulo deste trabalho, o surgimento da presença de elementos sagrados e profanos em uma mesma manifestação religiosa aconteceu devido às religiões negras serem proibidas pela Igreja Católica. Dessa forma, como maneira de preservar parte de sua identidade e de sua tradição, os negros associaram os elementos originais de sua cultura com o catolicismo dentro das irmandades as quais foram obrigados por seus donos a integrar quando chegaram ao Brasil.

De acordo com Boschi (1986) as irmandades são associações de caráter religioso, cuja identidade é definida por um compromisso ou estatuto, a marca de sua constituição enquanto organismo. Sua presença no Brasil é forte desde o início da colonização, podendo-se distinguir dois tipos básicos: as que se destinam à assistência social e as que se 
dedicam às atividades devocionais (como é o caso da Irmandade de Nossa Senhora dos Prazeres, presente em Lavras Novas), que tinham como principal atividade às celebrações a um santo patrono.

As irmandades desempenharam papel singular na capitania de Minas Gerais desde os setecentos, como afirma Boschi (1986). Constituídas por leigos, essas associações ganharam visibilidade no cenário colonial. As comemorações em torno dos santos eram uma de suas várias atividades, dentre as quais os quesitos de vistosidade e brilhantismo destacavam como metas principais. Os irmãos associados às irmandades não mediam esforços para a homenagem de seus padroeiros, cujos resultados poderiam ser apreciados na construção de capelas e no momento de celebrações coletivas.

Com a chegada do negro ao Brasil e com a proibição de suas cerimônias religiosas, se formaram as irmandades negras, nas quais os escravos poderiam ter mais liberdade na execução dos cultos. Dentre as irmandades devocionais negras mais conhecidas se destaca a de Nossa Senhora do Rosário, a qual construiu uma capela dedicada à santa em Vila Rica com ouro extraviado das minas onde os escravos participantes da irmandade trabalhavam.

Assim, muitas das cerimônias religiosas tipicamente católicas receberam vários elementos vindos da cultura africana e foram transformadas em festas, com o deslocamento de muitos dos cultos católicos de dentro das igrejas para a rua, para o espaço público, remetendo a formação de terreiros. Terreiros antes tidos como base para a realização de cerimônias ligadas a religiões africanas, como o candomblé, o vodum, o tambor de mina, etc. A partir desta mistura, muitas das celebrações católicas ganharam novos ritmos na música, foram acrescentadas danças tipicamente negras e o colorido nas roupas. A relação feita pelos negros entre os santos católicos e os orixás de sua cultura também facilitou sua contribuição nas celebrações católicas.

É importante ressaltar que o sincretismo religioso e que os elementos de miscigenação criaram uma nova forma de conceber a religiosidade, porém uma nova forma pautada sempre, primeiramente, na lógica do dominador, ou seja, mantendo sempre uma base católica portuguesa inalterável em sua conceituação, que abriu pressupostos apenas nas maneiras como poderiam ser manifestadas. 
Neste sentido cabe resgatar considerações de Chauí (2000), ao afirmar que a cultura popular se constrói por práticas feitas dentro de uma cultura dominante, sendo esta de acordo ou não, com a intenção de apropriação ou resistir ao mesmo.

Assim, se torna de suma importância o estudo das festas populares subalternas e suas diferentes liturgias para compreender o significado que elas têm na cultura popular brasileira, que embora em seu surgimento fossem elitistas, oficiais, foram apropriadas pelas culturas populares subalternas que as ressignificaram.

Dessa forma, as festas foram convertidas em espaços de celebração não elitizados, muitas vezes fugindo aos ritos oficiais ou sagrados, celebrando de uma nova maneira os santos católicos, os patronos e as datas de ocorrência importantes.

Para José Marques de Melo as festas populares funcionam como ativadoras das relações entre os seres humanos e são ao mesmo tempo articuladoras das relações institucionais e acabam por resgatar a identidade comunicacional dos grupos, uma vez que:

“...a gênese da festa localiza-se no imaginário coletivo, sendo resgatada periodicamente através dos fluxos de comunicação interpessoal (...) que desencadeiam iniciativas de celebração, apropriadas pelas instituições sociais." ( MELO, 2000: 61)

De acordo com o que afirma o autor, as festas se tornaram possíveis, dentro das ressignificações negras somente por não fugirem às apropriações aceitáveis à sociedade colonial. Desta maneira os elementos negros passaram a fazer parte de festas tipicamente européias, modificando a forma como se provocava significado no imaginário coletivo, agindo como uma forma de resistência da cultura popular negra, tão inferiorizada pelo colonizador.

Tendo em vista esta relação das festas com o imaginário coletivo, pode-se considerar que é exatamente através da criação de um novo imaginário que se dá a resistência das culturas colonizadas no Brasil. E é da mesma forma, e com as constantes transformações devido ao dinamismo presente nas culturas populares, que estas festas resistem até a atualidade.

Um exemplo disso se encontra nas festas conhecidas como reisados, onde geralmente está presente algum tipo de congado, em que se faz a coroação de santos cristãos, que inicialmente serviam para aludir à coroação de reis e rainhas africanos. Estas 
festas, como a Festa do Divino Espírito Santo, modificadas pelas irmandades negras, prevalecem até hoje. Segundo Ferreira:

“... constatou-se a existência de conjuntos expressivos de manifestações da cultura brasileira que tem suas origens na época da colônia e que hoje resistem a de diferentes formas à homogeneização imposta pelo projeto neoliberal. Estas manifestações culturais são de caráter tanto religioso como profano; são os reisados, Festa do Divino, as congadas, o jongo, as danças xibas, Cana Verde, os cirandeiros, catiras, ou festas tradicionais como o tropeirismo." (FERREIRA, 2005: 61)

Considerando a festa e sua miscigenação entre elementos sagrados e profanos, fazse necessário relembrar que os rituais e costumes do passado não representam mero conservadorismo, pois representam uma forma de resistir aos efeitos deformadores da cultura hegemônica. Nestas manifestações podemos também encontrar soluções para o presente, pois a resistência advém justamente de uma base que conserva a identidade.

Ferreira afirma que: “A exuberância destas manifestações põe em destaque a criatividade das populações subalternas, que sabem usar sua imaginação e sua arte para reverenciar suas crenças, muitas vezes superando dificuldades materiais para celebrar seus rituais". (FERREIRA, 2005: 62)

Tendo em vista a relação das festas com o imaginário coletivo e com a identidade de diferentes grupos, é possível encontrar nas liturgias das festas populares as mais diferentes manifestações populares. Destacam-se bailados (congada, bumba-meu-boi, etc.), dança (cururu, cateretê, quadrilha, etc.), recreação (folguedos e jogos), ritos (malhação do Judas, etc.) e sabença (medicina rústica), mitos e lendas (saci, mula-sem-cabeça, etc.), artes populares e técnicas tradicionais (comidas, cerâmicas, etc.), música (música de roda, cantigas e moda, etc.) e linguagem oral (poesia popular, anedotas, literatura de cordel, etc.).

Das inúmeras festas realizadas no país destacam-se as do Solstício de Verão, cujas representações mais conhecidas são o Natal e a Folia de Reis; e as do Solstício de Inverno, que receberam inúmeras adaptações, sendo as mais conhecidas: a Festa de São João, as Festas Juninas, e a Festa do Divino Espírito Santo ou, simplesmente, Festa do Divino, que a depender da localização geográfica no Brasil, pode acontecer de formas distintas: em terra ou em água. 
"Todas essas festas de origem cristã trazem a tona uma identidade cultural que resiste ao tempo e às influências da globalização. Possuem uma força que é a herança cultural de milênios." (WATANABE, 2005: 88)

A preservação das festas populares e da essência de suas manifestações constitui uma perpetuação resistente no inconsciente coletivo. Significa uma ligação entre passado e presente, que se exprime na cotidianidade, e tem seu ápice no momento mágico da festa.

Hoje, centenas de anos após o início da colonização luso-espanhola de fé cristã e de neoliberalismo que tentaram de todas as formas desarticular e destruir culturas milenares, tradições e visões de mundo que se opusessem à lógica de mercado, os ataques às culturas populares subalternas continuam, porém de forma mais sutil.

O subjugar o outro e a dominação não se dão mais, somente, no terreno religioso, envolvem muitos outros aspectos ainda não existentes durante a colonização. Atualmente o legado cultural popular e suas manifestações sincréticas sofrem ataques que procuram menos destruir as culturas populares, e mais conseguir lucros através de sua transformação em produtos da indústria cultural. A religião como arma de dominação foi substituída pela parceria da indústria com os meios de comunicação de massa. A sutileza empregada na atuação destes mecanismos dessignificadores dentro das culturas populares, que transformam as festas populares em espetáculos a serem observados, através da difusão do turismo predatório, dificulta a articulação de mecanismos de resistência, justamente por se dar de forma velada.

Assim, considerando o sincretismo entre sagrado e profano como base das festas pesquisadas em Lavras Novas, foram abordados os processos identitários da comunidade, atendo-se principalmente às transformações ocorridas nas festas populares da região nos últimos anos, no sentido de avaliar as trocas e os impactos ocorridos na comunidade.

Nas festas pesquisadas (Festa do Divino e de Nossa Senhora dos Prazeres e a Encomendação das Almas) analisaram-se elementos que podem ser considerados de resistência e, ao mesmo tempo, se está ocorrendo o turismo predatório. Para isso se fizeram imprescindíveis o entendimento do surgimento destas festas no Brasil, em Minas Gerais e posteriormente no distrito de Lavras Novas, sua importância dentro da comunidade e os valores simbólicos a que se remetem. 


\section{2 - A Festa do Divino e de Nossa Senhora dos Prazeres}

Como em Lavras Novas a celebração ao Divino Espírito Santo e a Nossa Senhora dos Prazeres acontecem em uma mesma data, tornando-se uma só festa, se faz necessário, antes de entrar no terreno das peculiaridades desta festividade, estudar as matrizes históricas de cada uma delas em separado. Assim, posteriormente, este trabalho abordará a Festa que acontece em Lavras Novas, onde a junção entre as duas cerimônias aumenta ainda mais o sincretismo, transformando a mistura entre duas celebrações em uma terceira.

\subsection{1 - Festa do Divino Espírito Santo}

As festividades referentes ao Divino Espírito Santo não se atêm ao território de Lavras Novas, ou mesmo ao território mineiro. Apesar da existência de muitas destas celebrações nas Minas Gerais, este tipo de festividade existe no Brasil todo de forma marcante, possuindo traços peculiares em cada região do país. Assim, se faz necessária uma recuperação da historicidade da Festa do Divino para que possa se configurar seu início e perpetuação na comunidade de Lavras Novas como um dos territórios onde acontece esta celebração para, posteriormente, analisar suas peculiaridades.

O Divino representa a terceira pessoa da Santíssima Trindade e, concomitantemente, alude a uma figura una e indivisa, remetendo ao sentimento de união. Por isso mesmo não é eleito orago de uma confraria, padroeiro de nenhum lugar ou instituído protetor de uma categoria específica de pessoas. De acordo com os dogmas do cristianismo, o Divino possui papel igual ao Pai e ao Filho, tendo na pomba branca uma de suas expressões universalmente conhecidas.

Segundo Moraes Filho (1967) a Festa do Divino surge como resultado da marcante presença do catolicismo na fundação dos Estados Modernos Europeus, sobretudo no Estado Português, no final da Idade Média. A Festa do Divino foi instituída em Portugal nos primeiros anos do século XIV pela Rainha Izabel, mulher de D. Diniz, quando foi construída a igreja do Espírito Santo, em Alenquer.

De acordo com o autor, muitos dos elementos presentes nas celebrações portuguesas já eram remanescentes do tempo do Império Romano do Ocidente, como o bodo 
(distribuição de comida, como pão e carne a mendigos, pobres e presidiários), estes elementos perpetuaram por séculos até chegarem às tradições portuguesas e hoje fazem parte de muitos traços identitários de caráter simbólico das culturas subalternas no Brasil.

Assim, as relações entre antigos rituais greco-romanos se consolidaram na Idade Média por meio da ação e influência do recém formado Império de Portugal. O caráter contemporâneo da Festa do Divino foi gerado a partir da influência de diversos processos históricos e religiosos, miscigenando elementos sagrados e profanos.

Segundo Emilio Willems apud Prudente (2010) as festividades do Domingo de Pentecostes (50 dias após a Páscoa) eram tradicionais nas cortes lusitanas no Palácio de Cintra, onde a Rainha Izabel cuidava da distribuição de alimentos a pobres e doentes em conjunto com os participantes da festividade do Espírito Santo. Segundo Prudente:

"O ato de distribuição de alimentos é remotamente atribuído aos gregos. Em seguida foi incorporado pelos romanos, quando foi conhecido como panis gradilis. Com a expansão do Império Romano, dado o apogeu edificado pelo período do século de ouro, durante o governo dos imperadores da casa dos Antoninos, chegou à Península Ibérica num processo de simbiose." (Prudente, 2010: 123)

O pão e a carne eram os alimentos mais comuns distribuídos durante as celebrações do Divino pela Rainha Izabel. Com o tempo essa prática se espalhou para as demais localidades do Reino de Portugal, até chegar ao Brasil através da Coroa Portuguesa, onde os alimentos típicos a serem distribuídos se diversificaram.

Pode-se dizer que a influência para a celebração do Divino no Brasil ocorreu devido à popularidade da festa em Portugal e da grande devoção da Coroa Portuguesa, que trouxe a celebração para o Brasil durante a colonização, onde a festividade se misturou a características consideradas profanos, devido à influência da cultura indígena e da cultura africana.

Conforme Percival Tirapeli apud Prudente (2010) existe uma matriz portuguesa inseparável da Festa do Divino Espírito Santo. Conforme suas pesquisas o autor afirma que o primeiro registro desta festa no Brasil é de 1761, em Guaratinguetá, Vale do Paraíba. 


\subsection{2 - A Festa de Nossa senhora dos Prazeres}

Variadas são as especificidades da figura maternal de Maria, as quais se alternam conforme os diferentes contextos históricos. Se por um lado os cultos da Idade Média se se apresentam diferentes em relação aos contemporâneos, interessa registrar a gama de adjetivos concedidos a santidade da Mãe de Jesus Cristo - Nazaré, Rosário, Conceição e Aparecida são apenas alguns dos atributos compartilhados por fiéis de todo o mundo para nomear Maria.

Segundo Tavares (1990) no caso específico de Nossa Senhora dos Prazeres, os seus respectivos atributos tiveram início em Portugal por volta do ano de 1590. Segundo o dicionário de santos escrito pelo autor, conta-se que houve uma aparição da Santa ao lado de uma fonte onde havia sua imagem, em Alcântara, na quinta dos condes da ilha. Muitas pessoas que iam até a fonte para beber água afirmaram que conseguiam curas milagrosas, e logo a popularidade da virgem cresceu.

Os condes proprietários da fonte decidiram, então, levar a imagem para dentro de casa, mas logo depois a imagem desapareceu até que foi encontrada sobre um poço. Conforme se conta, uma menina que foi ao poço beber água aproximou-se da imagem e, então, Nossa Senhora se manifestou e pediu que os habitantes do local construíssem ali uma igreja e que ela devia ser invocada como Nossa Senhora dos Prazeres. A menina relatou o fato com tamanha seriedade que o povo não duvidou de seu depoimento. Então, foi construída a igreja que logo se tornou um local de peregrinação e onde há o relato de muitas graças alcançadas.

Nossa Senhora dos Prazeres é a mesma Nossa Senhora das Sete Alegrias. A disseminação de sua devoção é de origem franciscana, isto porque os prazeres, ou alegrias, de Nossa Senhora foram escritos por um franciscano. São eles: a Anunciação, a saudação de Isabel, o Nascimento de Jesus, a visitação dos Reis Magos, o encontro com Jesus no Templo quando ele conversava com os doutores da Lei, a aparição de Jesus Ressuscitado e a coroação de Maria no céu.

São muito poucas as localidades brasileiras que tem Nossa Senhora dos Prazeres como Padroeira, dentre elas se destacam Maceió-AL e Lages - SC. Não se sabe ao certo o motivo que levou Nossa Senhora dos Prazeres a ser escolhida como padroeira do distrito de 
Lavras Novas, alguns moradores da localidade afirmam que ter sido devido a algumas aparições da Santa na região das lavras, logo no início do século XVII. Inúmeras são as lendas que tentam explicar o motivo da devoção a Nossa senhora dos Prazeres na comunidade, a maioria delas relacionadas a aparições constantes da Santa, inclusive existem moradores que afirmam te-la visto em diversos lugares de Lavras Novas.

Antônio Alves Viana, de 95 anos e morador de Lavras Novas, é um dos que afirma ter visto Nossa Senhora dos Prazeres na comunidade:

"Eu vi ela viva, vivinha. Ela me apareceu e eu fiquei parado, arregalado assim, olhando, e isso não tem muito tempo não, tem uns 3 anos só. Ela me apareceu, mas não me disse nada. Era muito bonita, ela iluminava muito por onde passava. Eu estava lá na Pedra da Alzira, voltando pra casa. Ela me apareceu vivinha e eu vi. Eu vi." ${ }^{59}$

Dona Lídia Oliveira Ribeiro de Carvalho, de 83 anos, também afirma ter presenciado aparições da Santa:

"Eu me lembro que eu estava catando umas frutinhas pra comer, perto da pedra aqui de baixo, mas eu era menina ainda, devia ter uns 12 anos. Uma dona muito bonita me apareceu, sentou a meu lado e sorriu. Ela ficou me olhando e brilhava tudo em volta. Eu como era criança, meio bobinha ainda, não disse nada, saí correndo pra falar pra minha mãe, mas quando voltei com mamãe ela não estava mais, mas o brilho dela ainda estava lá, mamãe viu, meus irmãos viram." ${ }^{6}$

Segundo o historiador João Paulo Martins ${ }^{61}$, do arquivo histórico de Ouro Preto, a afirmação de visões da Santa pelos moradores é antiga, existem inclusive cartas e documentadas que comprovam a existência de relatos de visões da Santa na comunidade já em meados do século XVIII. É provável que as aparições e a grande devoção do povo da localidade a Nossa Senhora dos Prazeres seja ainda anterior a 1725, data em que constam em documentos que a Igreja que leva o nome da santa já estava pronta, pois esta foi construída em homenagem a ela.

\footnotetext{
${ }^{59}$ Fonte: trabalho de Campo realizado em 18 de outubro de 2009

${ }^{60}$ Fonte: trabalho de Campo realizado em 17 de outubro de 2009.

${ }^{61}$ Fonte: trabalho de Campo realizado em 16 de outubro de 2009
} 
"Realmente é intrigante esta devoção do povo a Nossa Senhora dos Prazeres ser tão grande e tão antiga, já que ela é bem pouco popular, mesmo em Portugal. É provável que alguma família portuguesa importante que veio se estabelecer na região procurando ganhar dinheiro com a mineração, tenha trazido a devoção a santa para a região de Lavras Novas e esta devoção tenha se espalhado, ou mesmo que algum pároco das redondezas tenha instaurado esta crença na comunidade, mas não se pode afirmar nada com precisão."

Cumpre ressaltar ainda que a Imagem de Nossa Senhora dos Prazeres presente na comunidade de Lavras Novas fora concebida ainda na primeira metade do século XVIII, segundo o plano de Inventário do acervo cultural de Ouro Preto (2005). De acordo com o inventário a própria Irmandade de Nossa Senhora dos Prazeres se responsabilizou pela encomenda da imagem, constando isto nos arquivos da mesa administradora da Irmandade. Porém, não há registros mais sistemáticos sobre as posteriores reformas da capela e intervenções na imagem da santa.

\subsection{3 - Nossa Senhora dos Prazeres e o Divino: duas celebrações em uma festa} só.

Em Lavras Novas a Festa do Divino ocorre concomitantemente à Festa de Nossa Senhora dos Prazeres, geralmente no mês de agosto, data de comemoração do Divino. A união das duas festas ocorreu na década de 80, depois da criação da Mesa Administrativa dentro da Irmandade de Nossa Senhora dos Prazeres, mas não há como precisar a data.

No ano de 2009, por considerar a Festa de Nossa Senhora dos Prazeres de maior importância para a comunidade por ser sua padroeira, a Irmandade de Nossa Senhora dos Prazeres, organizadora das festas religiosas da comunidade optou por manter juntas as duas festas, realizando a celebração da Festa do Divino e de Nossa Senhora dos Prazeres no mês de setembro, mês da padroeira do distrito: Nossa Senhora dos Prazeres.

Segundo Dona Prosperina Lessa Viana, membro da Mesa Administrativa das festas da comunidade junto a Irmandade de Nossa Senhora dos Prazeres, há cerca de 30 anos as Festas do Divino e de Nossa Senhora dos Prazeres ocorriam separadamente, mas como as datas eram muito próximas, uma em agosto e outra em setembro, era difícil arrecadar

\footnotetext{
${ }^{62}$ Fonte: trabalho de Campo realizado em 16 de outubro de 2009
} 
verbas, daí então, por uma questão financeira, a Irmandade resolveu junta-las em uma só. Segundo Dona Prosperina Lessa Viana:

"Eu até falei com o pessoal da Irmandade pra organizar o Divino no dia dele, que o certo é no Dia de Pentecostes, e o dia da Santa, de Nossa Senhora dos Prazeres no dia dela, dia 8 de setembro, mas, realmente tem que por as duas festas juntas pra, digamos, economizar. E também é que as duas festas se juntaram há muitos anos, sempre foi assim, aí, como sempre foi assim a gente continua fazendo assim. Daí eu falei lá na Irmandade que já que tinha de fazer as duas coisas juntas, que era mesmo melhor dar mais visão pro nome de Nossa Senhora, né? É ela que toca esse povo aqui todo pra frente, ajuda a gente." ${ }^{63}$

Assim, como acontece tradicionalmente, as duas celebrações se dão em uma festa só, dedicada ao mesmo tempo ao Divino Espírito Santo e à Padroeira da comunidade. Esta grande festa, que agora acontece próximo ao dia oito de setembro, dia de Nossa Senhora dos Prazeres, é organizada pela Mesa Administrativa da Irmandade de Nossa Senhora dos Prazeres, composta por moradores da comunidade que são divididos em equipes para o trabalho de preparação das festas.

Se por um lado a Igreja Católica almeja maior direcionamento por parte da programação, os irmãos não deixam de dotar as festas com feições particulares. Há muitos anos o corpo organizativo da Irmandade mantém a Mesa Administrativa com plenas atribuições. A Mesa Administrativa da Irmandade é eleita bienalmente,e composta por um diretor, um vice-diretor, tesoureiro e secretários, e são os membros da comunidade que ocupam os referidos postos.

$\mathrm{Na}$ época das festas a Irmandade de Nossa Senhora dos Prazeres recebe ajuda direta dos moradores da comunidade, bem como de donos de pousadas e restaurantes. A preparação para a Festa de Nossa Senhora dos Prazeres e do Divino começa vários meses antes, bem como a maioria das festas religiosas organizadas pela Irmandade. Dona Prosperina afirma que:

"Toda ajuda é bem vinda par a organização da festa, mas quem decide as coisas no final é a Mesa mesmo, na Irmandade. Muita gente dos distritos de fora, muitos fiéis da cidade de Ouro Preto e até gente de fora se oferece todo ano pra ajudar, aí fica mais fácil pra dividir as tarefas, ainda mais

\footnotetext{
${ }^{63}$ Fonte: trabalho de campo realizado em 05 de maio de 2010.
} 
quando todo mundo fica alegre de poder dar uma festa dessas né? Tem é que ficar feliz mesmo." ${ }^{64}$

A programação da Festa do Divino e de Nossa Senhora dos Prazeres não se altera muito de um ano para o outro, segue uma espécie de tradição, um roteiro, repetido ano após ano. Existem modificações de um ano para outro, porém nada que transforme a essência da cerimônia. Geralmente as datas de comemoração dessa festa sofrem alterações de acordo com os dias da semana em que caem. Por exemplo, em 2010 o dia de Nossa Senhora dos Prazeres, dia oito de setembro, caiu em uma quarta feira, então os dias finais de comemoração à santa foram transferidos para o final de semana. ${ }^{65}$

Segundo Seu Carlos Aurélio de Carvalho, 77 anos e membro da Irmandade, realmente é preciso mudar a data das festas para o final de semana seguinte:

"Não tem como fazer uma festança muito grande aqui durante a semana. Muita gente aqui trabalha em Ouro Preto, ou mesmo por aqui. Todo mundo tem que dar duro durante a semana, não tem como dedicar muito. Por exemplo, eu tenho que fazer minhas encomendas da cooperativa, outro tem outra coisa; outro, outra. Mesmo, por exemplo, tem a banda que a Irmandade chama pra tocar, o pessoal que vem das cidadezinhas perto participar... tem muita gente, e o povo vem pra festejar a santa mesmo, o Divino." 66

Ao ser indagado se essa mudança de data da festa tem também o objetivo de atrair turistas, Seu Carlos responde:

"Nós aqui temos o objetivo de trazer pra festa só os turistas que vem pra participar da festa mesmo, que respeitam, que têm fé, mas como é no final de semana, ou às vezes até cai no feriado, acaba coincidindo coma vinda de turistas que nem sabem da festa, mas na maior parte dos casos os turistas respeitam. Quando acontece alguma algazarra que atrapalha, som alto, os moradores se juntam e vão repreender a pessoa. Mas a maioria de quem vem de fora é gente daqui de perto mesmo, que pega pouso na casa do povo daqui mesmo." 67

\footnotetext{
${ }^{64}$ Fonte: trabalho de campo realizado em 05 de maio de 2010.

${ }^{65}$ Fonte: trabalho de campo realizado em 05 de maio de 2010.

${ }^{66}$ Fonte: trabalho de campo realizado em 04 de maio de 2010.

${ }^{67}$ Fonte: trabalho de campo realizado em 04 de maio de 2010.
} 
Dessa maneira, a Irmandade acaba por seguir uma regra: quando a data certa de comemoração da festa se dá no meio da semana, esta é transferida para o final de semana mais próximo.

As homenagens à Padroeira da comunidade e ao Divino iniciam-se nove dias antes do sábado festivo, com adorno de bandeirinhas coloridas na praça do distrito, no adro da igreja, e com novenas que são rezadas dentro da igreja todos os dias pelos fiéis.

Logo no primeiro dia de reza a igreja já se encontra toda enfeitada com flores, principalmente no altar. Porém, é no sábado festivo, nono dia de reza, que o templo recebe o maior número de fiéis.

Neste último dia da reza da novena acontece uma procissão rumo a Igreja de Nossa senhora dos Prazeres, a procissão tem como ponto de partida a casa de algum dos moradores da cidade, escolhido pela Mesa Administrativa da Irmandade de Nossa Senhora dos Prazeres, variando a cada ano. Esse morador recebe o nome de mordomo. Segundo D. Efigênia Vieira Viana, de 69 anos, quase todos os anos existe disputa entre os moradores para ser mordomo da festa:

"O pessoal aqui leva a sério mesmo o negócio (risos). O povo disputa pra ver quem vai dar saída na procissão, mas é tudo tranqüilo, claro, sem má querência. Até um pessoal de fora que veio morar aqui estava querendo ser mordomo ano passado, mas também, quem que não ia querer ter o Divino e Nossa Senhora dos Prazeres dentro de casa? Não é mesmo? Isso todo mundo quer mesmo, ela é muito milagrosa, traz muita coisa boa." 68

Partindo da casa de um dos moradores (o primeiro mordomo) a procissão com as bandeiras do Divino e de Nossa Senhora dos Prazeres segue pelas ruas de Lavras Novas acompanhada pelas músicas entoadas por uma banda. ${ }^{69}$ Os seguidores da procissão são muitos, muitas mulheres usam calças compridas por baixo de saias de chitão, e é comum encontrar vários adornos feitos com este tecido e com fuxicos coloridos. As bandeiras são levadas por moradores da comunidade, passando posteriormente pela casa de um segundo

\footnotetext{
${ }^{68}$ Fonte: trabalho de campo realizado em 05 de maio de 2010.

${ }^{69}$ A banda de música sempre é contratada de outros distritos próximos, pois a comunidade de Lavras Novas não possui mais sua própria banda, a qual foi extinta no ano de 2004 por falta de músicos. No ano de 2008 e 2009 foi contratada a Corporação Musical Bom Jesus das Flores, oriunda de Ouro Preto. As festividades de 2009 também contaram com a participação da Corporação Lira Santa Rita, de Viçosa - MG.
} 
morador da comunidade (o segundo mordomo), e continua pela Rua Nossa Senhora dos Prazeres até chegar na capela dedicada à santa.

Ao chegar na entrada do santuário as flâmulas sagradas ganham uma salva de palmas, além de serem veneradas com cânticos entoados pelo Coral Nossa Senhora dos Prazeres. Na seqüência, meninas da comunidade vestidas de anjo realizam a coroação da padroeira da comunidade sob o hino da virgem dos Prazeres:

"Louvores e prazeres, augusta Senhora,

Fonte de alegria ao seu coração.

Fonte de alegria ao seu coração.

Jesus é um grande nome.

É o nome de poder, de altas majestades,

que sois augusta dos Prazeres.

De altas majestades,

Que sois augusta dos Prazeres" 70

Por fim acontece a bênção das flâmulas carregadas durante a procissão e as bandeiras dos homenageados são erguidas em um mastro, situado no adro. Após todos os fiéis terem saído da igreja, se inicia um show de queima de fogos, e a fogueira atrai as pessoas para sua volta. Segundo a Mesa Administrativa da Irmandade os fogos são uma prática nova na festa, e foi incorporada há cerca de 10 anos. Juliana Dias, de 50 anos, é natural de Ouro Preto e veio até Lavras Novas para apreciar a festa:

"Adoro ficar aqui do lado da fogueira olhando o movimento, conversando com o pessoal daqui. Tem uns 20 anos que eu venho todo ano aqui. Eu participo da Irmandade do Rosário em Ouro Preto e adoro esse tipo de festa que tem aqui em Lavras Novas. Aqui é... é... tudo de coração mesmo. Eu venho pra festa mesmo, sou muito católica, mas tem muita gente que vem pra bagunçar só e não está nem aí pra festa, mas hoje o povo da cidade aqui, se tiver atrapalhando, chama a atenção e até manda embora daqui. Mas, até que não tem tido mais isso não, já teve mais, hoje é só um ou outro caso. Mesmo quem não vem pra festa respeita, vem olhar e acaba gostando. Não tem como não gostar." 71

\footnotetext{
${ }^{70}$ Fonte: trabalho de campo realizado em 12 de setembro de 2009.

${ }^{71}$ Fonte: trabalho de campo realizado em 13 de setembro de 2009.
} 
Os moradores, visitantes e turistas se unem em volta da fogueira e em torno das barraquinhas que são montadas para a venda de diversos tipos de comidas típicas. O dinheiro arrecadado ajuda a suprir os custos da Festa.

No palco montado na praça do distrito são apresentadas músicas entoadas pelo grupo de mulheres que procura resgatar a marujada na comunidade. É o grupo Nananá, montado por Suzana Menezes Macedo, que divide o palco com apresentações infantis de adoração a Nossa Senhora e ao Divino, variando de ano para ano. No final de semana que envolve a festa os restaurantes e bares ficam lotados e várias programações paralelas são oferecidas, como shows nos bares e passeios ecológicos, porém somente em horários que não interfiram nas celebrações ligadas à festa.

A banda toca até de madrugada e a festa dura até o raiar do sol, cerca de 5 horas da manhã, quando, em seguida, inicia-se a Alvorada. O anúncio do dia principal se dá por meio de foguetes, repique de sinos, de toque de tambores e das músicas entoadas pela banda que percorre a Avenida principal da cidade. Esta é uma ocasião um pouco mais descontraída, onde a população segue a banda cantando, pulando e assoviando. Dentre os sons embalados pelos freqüentadores da Alvorada destaca-se a melodia Oh Minas Gerais, cujos versos conhecidos ajudam a despertar a população de Lavras Novas para a manhã de domingo. Muitos dos moradores da cidade saem às portas e janelas de suas casas enrolados em cobertores para ver a Alvorada passar.

A Alvorada termina no portão da igreja de Nossa Senhora dos Prazeres e os fiéis se preparam para assistir a missa em homenagem a Nossa Senhora dos Prazeres. Apesar de não possuir um pároco fixo para o atendimento à comunidade, a festa reúne vários padres da região. Em 2009, estava entre eles o bispo da Diocese de Mariana, Dom Barroso, que celebrou a missa da Alvorada.

Esta missa é transmitida às localidades próximas via rádio, atingido um público ainda maior, mesmo porque muitos fiéis não conseguem assistir a esta solenidade devido à lotação da igreja.

Findando a solenidade, ocorre o cortejo do Império do Divino Espírito Santo, cujo trajeto transita por algumas ruas do povoado até retornar ao templo. O cortejo é composto pelo Imperador, Imperatriz, Príncipe e Princesa, acompanhados da Vara, que simbolicamente protege as figuras da corte, as quais seguram as arestas de um quadrado 
com o intuito de delimitarem seus espaços. Existem duas categorias na Corte do Divino: a adulta e a mirim, que desfilam juntas.

Segundo Seu Carlos Aurélio de Carvalho, muitas pessoas se candidatam a fazer parte da Corte do Divino:

"Aqui tem muita gente querendo participar, colocar os mantos, as coroas e ir no cortejo, né? Mas são só um casal de crianças e um casal de mais velhos, não tem como por todo mundo. Aí, já teve ano que formou fila pro outro ano de gente querendo, mas aí ia ter gente pra uns três anos já, aí não podia definir tudo antes da hora, pra os outros anos, mas é bom que tenha gente." 72

Os quatro eleitos anualmente para o Império do Divino vão à cerimônia vestidos a caráter, com coroas, bastões e mantos. As roupas são bastante luxuosas, soando como fantasias. Porém, segundo D. Efigênia Vieira Viana, nem sempre foi assim.

"Antigamente a Festa do Divino era mais simples. Não tinha como mandar fazer roupa fora, não tinha jeito de mandar comprar nada, então era tudo as mulheres daqui mesmo que faziam. Por exemplo, se minha filha ia ser Princesa do Divino, eu que tinha de fazer a roupa dela. Todo mundo fazia assim, toda mulher aqui sabe costurar, que mulher tem que saber (...) e até que ficava bonito, mas não se compara com as coisas que tem hoje.Era triste e bonito. Hoje é tudo mais ajeitado, mais parecido." 73

Suzana Menezes Macedo, moradora de Lavras Novas desde 1980, afirma que as mudanças na comunidade foram muitas com a chegada da televisão e com o aumento do turismo. Segundo ela é possível perceber os impactos desta relação em alguns detalhes, como por exemplo, nas roupas usadas na cerimônia do Divino Espírito Santo:

"Antes as mulheres faziam as roupas da festa, costuravam. Quando eu cheguei aqui era assim, ficou assim por um bom tempo ainda. Depois, com a chegada da televisão, a melhoria de acesso à comunidade, as coisas foram mudando aos poucos. Hoje nos temos Rei e Rainha do Divino de loja, de boutique, com roupas trazidas de Belo Horizonte, ou mandadas fazer em Ouro Preto. Ninguém mais quer fazer a roupa. As coroas que antes eram feitas de flores hoje são compradas. Eu acho isso um absurdo. Preferia

\footnotetext{
${ }^{72}$ Fonte: trabalho de campo realizado em 04 de maio e 2010.

${ }^{73}$ Fonte: trabalho de campo realizado em 05 de maio de 2010.
} 
como era antes. Os valores da Festa ficaram, são muito importantes, mas alguns detalhes como esse são uma perda." 74

Durante o cortejo uma das crianças, que representava a Princesa do Divino, afirmou que sua mãe mandou fazer sua fantasia e comprou os apetrechos em Ouro Preto. ${ }^{75}$

Os Imperadores e Príncipes do Divino, com seus adornos e bandeiras seguem pelas ruas da comunidade até chegarem à igreja de Nossa Senhora dos Prazeres, onde são aplaudidos e o bispo toma novamente a palavra para a realização de uma nova procissão, dessa vez em homenagem a Nossa Senhora dos Prazeres.

A procissão em homenagem à Santa é anunciada com tambores e repiques de sinos, criando uma melodia que faz lembrar uma espécie de congado. Logo depois a histórica imagem de Nossa Senhora dos Prazeres é colocada em um andor e carregada em procissão pelas ruas do distrito, acompanhada pelas bandas de música: a Corporação Bom Jesus das Flores, oriunda de Ouro Preto e a Corporação musical Lira Santa Rita, vinda de Viçosa MG. Nesta procissão, muitos fiéis tocam a imagem de Nossa Senhora dos Prazeres para fazer pedidos, por acreditarem ser esta imagem milagrosa.

No retornar da imagem à Igreja de Nossa Senhora dos Prazeres o Padre Luiz, de Ouro Preto, dá fechamento ao domingo festivo.

\section{3 - A Semana Santa e a Encomendação das Almas em Lavras Novas}

Para que este trabalho se atenha à análise do rito de Encomendação das Almas que ocorre em Lavras Novas durante a Semana Santa (objeto de estudo desta pesquisa), é necessário, primeiramente, resgatar a historicidade desta festividade, para que a partir daí possam-se entender as características próprias desta.

É comum que os ritos de encomendação das almas, presentes no catolicismo em várias localidades, aconteçam durante a quaresma e não na Semana Santa, daí se faz necessário o estudo das peculiaridades desta cerimônia na comunidade de Lavras Novas, e este trabalho iniciará esta análise a partir de uma visão ampliada da festividade de Semana Santa, para posteriormente se ater ao Rito de Encomendação das Almas.

\footnotetext{
${ }^{74}$ Fonte: trabalho de campo realizado em 13 de setembro de 2009.

${ }^{75}$ Fonte: trabalho de campo realizado em 13 de setembro de 2009.
} 


\subsection{1 - A Semana Santa}

A Semana Santa é um período religioso do Cristianismo que celebra a trajetória de Jesus Cristo até o Monte das Oliveiras, a sua crucificação e a sua ressurreição. Esta celebração, já recebeu vários nomes ao longo de sua disseminação pelo mundo, sendo também a cerimônia modificada com o passar do tempo.

No tempo dos apóstolos, a Semana Santa era celebrada informalmente, em dois dias: sábado de jejum rigoroso, em preparação para o domingo, em que se celebrava a ressurreição de Cristo. A partir daí, várias províncias próximas ao Império Romano passaram a celebrar a Semana Santa, porém, de diferentes formas e em diferentes datas.

Em 325, no Concílio de Nicéia, quando a religião católica passou a ser a religião oficial do Império Romano, foram estabelecidas novas diretrizes para a homogeneização das celebrações cristãs, dentre elas a Semana Santa.

O Concílio foi convocado com o intuito de resolver as muitas controvérsias entre os dogmas do cristianismo nas várias províncias onde ele era professado, em sua maioria no oriente. Compareceram ao Concílio de Nicéia cerca de 300 bispos.

A partir deste Concílio ficou decidida que a Semana Santa teria 3 dias. A Sextafeira da Paixão, dedicada ao dia da morte de Jesus; Sábado de Aleluia: dia consagrado ao luto; e a festa da ressurreição de Cristo no domingo. Foi decidida também a data em que seria feita a comemoração: primeiro domingo depois da primeira lua cheia que ocorre após o equinócio da primavera boreal. Esta institucionalização da data das festividades permanece até hoje, e por isso a Semana Santa é uma festa que varia sua data de ano para ano.

Com a difusão do cristianismo pelo mundo é que a Semana Santa passou a ser celebrada durante oito dias, sendo esta nova forma de celebrar reconhecida posteriormente pela Igreja Católica. O Domingo de Ramos abre a Semana Santa, remetendo a entrada de Jesus Cristo em Jerusalém; segunda-feira é o dia em que é relembrada a caminhada de Jesus rumo ao calvário; a terça-feira corresponde às sete dores de Maria; quarta-feira é o dia em que se encerra o período de Quaresma; quinta-feira é o dia em que é celebrada a última ceia; sexta-feira, também conhecida como Sexta-feira da Paixão, é o dia da morte de 
Cristo; o Sábado de Aleluia o dia de luto; e o domingo de Páscoa o dia da ressurreição de Jesus.

A festividade, como a maioria das de origem cristã, chegou ao Brasil trazida pelos portugueses e se espalhou por todo o país, criando peculiaridades de acordo com a influência sincrética e com os costumes dos locais onde se tornou tradicional. ${ }^{76}$

\subsection{2 - A festa em Lavras Novas}

Não se sabe ao certo quando as festividades de Semana Santa em Lavras Novas se iniciaram, porém acredita-se ter sido no auge do período da mineração, quando o vilarejo já estava mais desenvolvido, por volta do início do século XVIII.

A festa, que segue o calendário católico, geralmente acontece nos mês de março ou abril. Em 2010, a Semana Santa ocorreu do dia 28 de março ao dia 4 de abril.

Em Lavras Novas os preparativos para a festa se iniciam bem antes da data da comemoração, e a organização fica por conta da Irmandade de Nossa Senhora dos Prazeres e sua Mesa Administrativa.

Através da organização proposta pela irmandade, todos os moradores se reúnem e distribuem funções entre si, são também escolhidos os responsáveis pela arrecadação de doações em dinheiro para que, assim, possam juntos organizar e decorar toda a cidade para a Semana Santa.

O Santíssimo, representado por uma vela é aceso no primeiro dia da Quaresma, para simbolizar o primeiro dia da Páscoa. A cerimônia começa com a Fase Preparatória, que ocorreu, no ano de 2010, nos dias 21 a 27 de março, onde todas as mães da comunidade, padres, ministros e lideranças da Igreja Católica, participam da reflexão sobre as "Dores de Maria” na paróquia local. Esta reflexão acontece através de missas e rezas de terços diárias.

No dia 28 de março, dia em que se comemorou o Domingo de Ramos, foi realizada uma Procissão, com a presença dos jovens da comunidade. Esta procissão se inicia na escola da cidade e segue em direção à Igreja de Nossa Senhora dos Prazeres. No caminho são entoados hinos religiosos e acontece o repique de sinos e o toque de tambores. Os

\footnotetext{
${ }^{76}$ MORAES FILHO, M. Festas e tradições populares no Brasil. Rio de Janeiro: Garnier, 1967.
} 
participantes da procissão carregam flâmulas e palmas para relembrar a entrada de Jesus Cristo em Jerusalém. Quando a procissão chega à Igreja de Nossa Senhora dos Prazeres são distribuídas as palmas e em seguida é celebrada a Missa Solene de Ramos.

Na Segunda-feira Santa, dia 29 de março, ocorre a Procissão do Depósito do Senhor dos Passos que percorre a cidade até a Casa de Cultura Dedela, coordenada por Suzana Menezes Macedo. Na Casa de Cultura, localizada no final da rua principal, as mulheres da comunidade entoam hinos religiosos que remetem às origens africanas da comunidade, pois o Grupo Dedela tem como finalidade reviver a marujada (espécie de congado típica da região). A procissão, que segue com poucos turistas, aprecia apresentações do grupo na entrada da Casa de Cultura, que se encontra toda enfeitada para as festividades de Semana Santa.

Suzana Menezes Macedo afirma que:

"É muito importante não só reavivar a marujada no povoado, mas também reinserí-las nas festas da comunidade. Esse tipo de canto, congado, era comum no início do século XX e depois foi sumindo, mesmo porque a Igreja Católica começou a dizer que eram cantos de macumba, coisa do demônio e que era pecado. Mas graças a Deus os novos párocos que tem vindo para a região estão apoiando muito nossa iniciativa e o povo está tomando gosto por sua origem novamente. Eu adoro me juntar às mulheres aqui da comunidade para ensaiar, colocar bandeirinhas, palmas, enfeitar tudo." 77

Terça-feira, 30 de março, é dia da Procissão do Depósito de Nossa Senhora dos Prazeres. A procissão que se inicia no final da tarde, segue da Igreja até a escola municipal, que se encontra toda enfeitada com bandeirinhas, fuxicos e bandeiras de chitão. A procissão segue cantando o hino de Nossa Senhora dos Prazeres, alternado com outras músicas religiosas de devoção à santa. Depois a procissão retorna até a Igreja, onde é celebrada uma missa em homenagem à santa.

Dia primeiro de abril, quarta-feira, acontece a Procissão e Sermão do Encontro, onde é realizado o encontro da imagem de Nosso Senhor dos Passos com Nossa Senhora dos Prazeres. O encontro acontece no final da tarde: os homens saem em procissão da Igreja da comunidade carregando a imagem de Nosso Senhor dos Passos em um adro, passam por algumas ruas do povoado e posteriormente voltam à frente da Igreja. Já as

\footnotetext{
${ }^{77}$ Fonte: Trabalho de campo realizado em 29 de março de 2010.
} 
mulheres saem da casa de algum morador, escolhido pela Irmandade, na entrada da cidade, com a imagem de Nossa Senhora das Dores. Ao chegarem na entrada da Igreja acontece então o encontro entre Nossa Senhora das Dores e Nosso Senhor dos Passos, a fim de simbolizar o doloroso encontro entre Maria e Jesus, que carregava a cruz rumo ao calvário.

A Procissão do Encontro acontece como uma grande encenação: a população utiliza figurinos para representar a época. É interessante notar que muitas das roupas que procuram remeter a época da morte de cristo são feitas em hitão e confeccionadas pelas mulheres da comunidade. Por outro lado já existem roupas feitas sob encomenda, vindas de Ouro Preto ou Belo Horizonte. Segundo Suzana Menezes Macedo:

"Antes as encenações eram ainda mais simples, sem muitas falas e sem
muita preparação, era uma coisa mais espontânea. Agora as falas já estão
mais complexas e muita gente quer fazer roupas em outras cidades pra ficar
mais parecido com as encenações das grandes cidades, que aparecem na
televisão. Ainda bem que não tem muito turista na cidade pra ficar vendo
isso nesse dia, porque se não era bem capaz de algumas pessoas quererem
escrever roteiro para peça, e montar figurino de novela (risadas)." 78

Quinta-feira acontece a missa e o cerimonial do Lava-pés e a Adoração do Santíssimo Sacramento, posteriormente ocorre a tradicional Encomenda das Almas pelas ruas de Lavras Novas, a qual é objeto de estudo deste trabalho.

Para a solenidade de Lava-pés é montado um palco em frente a Igreja de Nossa Senhora dos Prazeres, onde ocorre uma encenação. Doze homens da comunidade são escolhidos para representar os apóstolos de Cristo e a voz do padre representa a voz de Jesus. Em volta do palco várias pessoas da comunidade se vestem de anjos e soldados romanos. Segundo os moradores da comunidade, as roupas são reaproveitadas de ano para ano e de uma festa para a outra. Carlos Aurélio de Carvalho afirma que:

"Lá em casa, minha Dona aproveitava as roupas das crianças tudo, ia parando de servir a roupa de anjo num ela passava pro outro, até acabar ou doar pra alguém. Mas lá em casa era minha mulher que fazia as roupas todas na máquina, só as asas de anjo que a gente emprestava da igreja ou comprava, que se fizesse não parava muito certo não. Hoje tem uns anjos muito mais bonitos no meio dos outros, uns anjos mais chiques né? ( risos) Mas eu acho bonito, sendo de bom grado pra Nossa Senhora é bonito., ${ }^{, 79}$

\footnotetext{
${ }^{78}$ Fonte: Trabalho de campo realizado em 29 de março de 2010

${ }^{79}$ Fonte: trabalho de campo realizado em 04 de maio de 2010.
} 
Primeiramente, o padre dirige um sermão aos fiéis que se encontram em frente ao palco, com um discurso sobre a igualdade entre os homens e a importância da humildade, então se coloca em frente aos 12 homens caracterizados de apóstolos e lava seus pés. Durante toda a solenidade são entoados cânticos, muitos deles pelas mulheres da Casa de Cultura Dedela.

Por fim, a imagem de Cristo é retirada da cruz, colocada em uma manjedoura e carregada ao longo da rua principal da comunidade. Esta procissão acontece em silêncio, sem cânticos, sem repique de sinos e tambores, até que a imagem de Jesus retorna à sala paroquial.

A comunidade é convidada a permanecer em adoração solene em suas casas para um momento de reflexão e reza. Daí então todos seguem para as suas casas e o silêncio impera. O sino da Igreja para de tocar até o dia seguinte e ouvir música em volume alto, beber, ou fazer festa são vistos como atos de blasfêmia.

Já com todos os moradores em suas casas, depois de cerca de 2 horas, 2 pessoas da comunidade, escolhidas previamente pela Irmandade, vão até o cemitério do distrito e batem matracas em cima de todas as sepulturas, como o intuito de acordar as almas, as quais receberam rezas e também receberam pedidos de favores.

No ano de 2010 Alderico Sabino Guimarães, de 32 anos, foi um dos que tocou a matraca no cemitério:

"O toque da matraca é como se fosse para as almas acordarem, para fazerem pedidos a quem reza por elas e também pra receberem os pedidos de quem precisa, de quem tem gente doente em casa, precisando. Aí pede pra parente falecido, pra os antigos. E serve pra avisar que é para o povo sair de suas casas que a Encomenda vai começar logo. Mas antes já está tudo preparado pra encomenda. Tem um grupo de mulheres que organiza a Encomenda junto a Irmandade, sabe?" 80

Depois de algum tempo o som da matraca em volta da igreja, convoca a todos a retornarem de suas casas e irem para a rua para participarem do ritual de Encomendação das Almas. O ritual é organizado por uma comissão de moradoras a parte da Irmandade

\footnotetext{
${ }^{80}$ Fonte: trabalho de campo realizado em 01 de abril de 2010.
} 
Nossa Senhora dos Prazeres, que ensaia durante semanas para puxar a procissão que se inicia sempre à meia noite.

Durante a cerimônia a comunidade se concentra em frente à porta da igreja, em silêncio e à luz de velas, para iniciar o traslado do Santíssimo. A procissão é puxada pelas mulheres da comunidade, que cantam o hino da Encomenda das Almas, sem nenhum acompanhamento musical, apenas ouvem-se alguns repiques nos sinos da Igreja de Nossa Senhora dos Prazeres:

\author{
"Alerta, alerta pecador, alerta \\ Quem está dormindo. Acordai \\ Olha que este sono é do pecado \\ É do pecado \\ Peço rezar um Padre Nosso com Ave Maria \\ Ave Maria \\ Pras almas que não tem ninguém por elas \\ Ninguém por elas \\ (Pausa para rezar, cerca de 20 segundos.) \\ Almas que se movem no pecado \\ É no pecado \\ Acordai \\ Peço rezar um Padre Nosso com Ave Maria \\ Ave Maria \\ Pras almas que não tem ninguém por elas \\ Ninguém por elas." 81
}

Durante toda a procissão são carregadas velas e feitas pequenas paradas em frente às tochas, que foram colocadas antes das comemorações da noite, diante das casas onde ocorre algum problema de enfermidade ou necessidades urgentes, para rezar em beneficio destas pessoas. As tochas são acesas antes da saída da procissão com a Chama do Santíssimo, que no final do percurso, é posto junto à manjedoura, na sala paroquial.

É interessante notar que no ano de 2009 o ritual de encomendação das almas não aconteceu por falta de pessoas interessadas em organizá-lo, junto à Irmandade do distrito. D. Prosperina Lessa Viana conta que:

\footnotetext{
${ }^{81}$ Fonte: trabalho de campo realizado em 01 de abril de 2010.
} 
"Na verdade aqui em Lavras Novas ficou um bom tempo sem ter a encomendação, mas isso já faz uns 20 anos, depois voltou a ter. E fui eu que fui na Irmandade falar pra reavivar isso aqui em Lavras Novas, eu e a Lídia, Lídia Afonso de Oliveira, que Deus a tenha, e tomamos as frentes de tudo, aí voltou a ter. Nesse ano que passou não teve porque não tinha ninguém interessado em organizar, e eu já estou muito velha, tem que ter gente mais nova interessada, e teve muito pouca gente interessada, aí não deu. Eu fiquei muito triste, mas não podia resolver isso sozinha, sou velha já. Mas esse ano teve, os próprios jovens ficaram tristes e resolveram organizar. Minha filha já faz tudo que eu fazia" ${ }^{82}$

Segundo D. Vera Lessa, muitas coisas mudaram desde que ela começou a freqüentar a Encomendação das Almas, quando criança:

\begin{abstract}
"As tradições antigamente eram mais respeitadas, como por exemplo, na cerimônia da Encomendação das Almas não se podia ter conversa, um respeito total (...) as coisas não são mais sinceras igual eram. As pessoas estão com a cabeça cheia e relaxada para muitas coisas (...) até que as pessoas vão para ver, não vão com aquele amor e com aquela sinceridade, aí a tradição estava acabando...não tinha mais gente pra fazer porque as pessoas mais velhas que cuidavam da festa estavam ficando cansadas...mas os jovens estão revivendo isso, viram que precisava. Está sendo passado para os mais novos. Os mais velhos vão, mas quem está segurando mais são os mais novos agora. Já foi escrito tudo (...) para não se esquecer as palavras. O povo não quer que acabe...." 83
\end{abstract}

Como a Encomenda das Almas remonta do período colonial, e a luz elétrica só chegou a Lavras Novas na década de 1970, muitos foram os mitos que surgiram na comunidade. Como por exemplo: que as velas viravam ossos na mão das pessoas se elas não respeitassem a Encomenda, que as pessoas veriam fantasmas se olhassem para trás, etc.

A Encomenda das Almas acaba por volta das 2 horas da manhã, então a população volta à suas casas em silêncio, por respeito às almas.

$\mathrm{Na}$ sexta-feira santa a população se penitencia com o jejum, e é conduzida pelos jovens para a Caminhada Penitencial e a Via Sacra, seguida pela solenidade de Ação Litúrgica em Memória à Sagrada Paixão e Morte do Senhor Jesus Cristo.

O altar improvisado na frente da igreja é iluminado, sem cruz, sem velas nem adornos, para recordar a morte de Jesus. Os ministros se colocam no chão, frente ao altar no

\footnotetext{
${ }^{82}$ Fonte: trabalho de campo realizado em 05 de maio de 2010.

${ }^{83}$ Fonte: trabalho de campo realizado em 01 e abril de 2010.
} 
começo da cerimônia, para representar a imagem da humanidade rebaixada e oprimida, e ao mesmo tempo para implorar o perdão por seus pecados. Nesse dia, não ocorre a celebração da missa, apenas são feitas leituras de adoração do Santíssimo.

No Sábado de Aleluia é realizada a Solene Vigília Pascal: Benção do Fogo Novo, Renovação das Promessas de Batismo, Liturgia da Palavra e da Eucaristia, e finalizada com a tradicional Malhação do Judas.

As imagens dos santos de dentro da igreja, que ficaram tapadas durante toda a Quaresma (acredita-se que o mal ronda a Igreja durante a quaresma) são desnudadas no sábado. À meia-noite os sinos da Igreja de Nossa Senhora dos Prazeres soam sete vezes e então os jovens, que esperavam do lado de fora, adentram a igreja cantando músicas religiosas, pulando e dançando para espantar o mal. As músicas são acompanhadas por toque de tambores e possuem ritmo forte, próximo ao congado.

Quando o sino ecoa a décima badalada os jovens saem da igreja e dão voltas em torno dela, se concentrando, posteriormente, em frente ao cruzeiro para a queima do Judas.

A queima acontece em meio a cantoria e bebidas. Quando o fogo é ateado ao boneco que representa Judas, muitos fogos de artifício são soltos e a festa continua ainda por algumas horas. Na sexta-feira já é grande o número de turistas que está na cidade, e muitos deles param para assistir a festa, outros permanecem nos bares e restaurantes da cidade ou nas casas alugadas.

No último dia da Semana Santa, domingo de Páscoa, os jovens e o Coral das Mães apresentam a solenidade de Celebração Eucarística, e a Procissão da Ressurreição, que é conduzida pelo Santíssimo Sacramento pelas ruas da cidade, encerrando com a Coroação da Imagem de Nossa Senhora dos Prazeres.

Neste último dia, a cidade amanhece com uma tapeçaria colocada na rua principal da cidade, feita durante a noite por um grupo de moradores. A tapeçaria possui desenhos feitos em serragem e sementes, e as casas são ilustradas com imagens religiosas, entre outros artesanatos. Mesmo quando o tempo está chuvoso, os lavra-novenses utilizam técnicas de pintura, para de alguma forma, manifestarem sua fé.

A procissão da Ressurreição, que se inicia logo pela manhã, sai da casa de um morador no início da cidade carregando a imagem de Nossa Senhora dos Prazeres e segue pelo tapete de serragem, acompanhada pela banda, que entoa, dentre várias canções a 
música Oh Minas Gerais. Após o termino desta melodia, os fiéis adentram a igreja para uma missa e para ouvirem o Coral das Mães. Nossa Senhora dos Prazeres então é coroada pelas crianças da comunidade vestidas de anjo. Após a saída da igreja a banda toca músicas próximo ao cruzeiro e muitos moradores permanecem ali ainda por algum tempo.

No domingo de Páscoa carros são proibidos de transitar na rua principal e existe a mobilização do comércio, que deixa de funcionar por algumas horas para que os moradores possam orar em silêncio e caminhar pelas ruas tranqüilamente.

Como a Semana Santa ocorre em uma época de feriado nacional, a relação desta com o turismo se dá de forma diferente do que acontece na Festa do Divino e Nossa Senhora dos Prazeres. No período de Semana Santa, principalmente a partir de quinta-feira à noite, o número de turistas na cidade é muito grande. Em alguns anos a comunidade que tem cerca de 1.5000 habitantes chegou a receber 5.000 turistas. ${ }^{84}$

\footnotetext{
${ }^{84}$ Prefeitura de Ouro Preto. Plano de inventário do acervo cultural de Ouro Preto: Secretaria Municipal de Cultura: 2005.
} 


\section{CAPÍTULO IV \\ AS FESTAS POPULARES E SUAS INTER-RELAÇÕES: A PESQUISA, A COMUNIDADE E OS TURISTAS}

Este capítulo tem como objetivo analisar a forma como se dá a interação entre as festas populares subalternas de Lavras Novas e a comunidade, e destas com o aumento constante do turismo na região. Visa, através da interação entre a teoria e a análise da vida cotidiana da comunidade, entender as diferentes formas de apropriação das festas pelo povo lavras-novense, bem como os mecanismos que regem cada uma destas formas em suas diferenças.

Para isto este trabalho recorreu à observação participante (tanto durante os períodos festivos, quanto em dias comuns), a entrevistas com os com os moradores da comunidade e turistas, e a documentos históricos encontrados em Ouro Preto e Mariana.

Ao todo foram realizadas 6 visitas a campo: a primeira de 14 a 19 de junho de 2007; a segunda de 30 de outubro a 3 de novembro de 2008; a terceira de 11 a 13 de setembro de 2009; a quarta de 15 a 18 de outubro de 2009; a quinta de 28 de março a 4 de abril de 2010 e a última de 3 a 9 de maio de 2010.

A primeira visita a campo compreendeu o conhecimento físico da comunidade e conversas informais com os moradores, foi também realizada uma visita à biblioteca Municipal de Ouro Preto para obtenção de cópias de documentos e jornais sobre o Distrito de Lavras Novas. Neste mesmo período foram gravadas a maioria das conversas com os moradores da comunidade utilizadas na produção do radiodocumentário Além da Lenda: A influência da oralidade na formação sócio-cultural de Lavras Novas, trabalho de conclusão de curso apresentado em dezembro de 2007 ao curso de comunicação da Universidade Federal de Viçosa, pela autora deste trabalho.

Já na segunda viagem, época da celebração de Finados, foram feitas entrevistas com turistas e moradores e outra visita a Ouro Preto e Mariana, compreendendo entrevistas e obtenção de documentos no Arquivo Histórico Municipal, na Casa dos Contos, na Casa do Pilar e na Arquidiocese de Mariana. 
A terceira visita a campo foi direcionada a observação da Festa do Divino e de Nossa Senhora dos Prazeres, bem como para fazer entrevistas sobre esta festa com os moradores e turistas presentes no distrito.

A quarta visita compreendeu a busca por documentos históricos em Ouro Preto e Mariana. Nesta visita a campo também foram realizadas entrevistas com o historiador da Prefeitura de Ouro Preto, João Paulo Martins, e com moradores de Lavras Novas.

Durante a quinta visita a comunidade de Lavras Novas foi feita a observação da cerimônia de Semana Santa e do ritual de Encomendação das Almas, neste período também foram feitas entrevistas com os moradores e os turistas.

A última viagem aconteceu durante a semana, período em que o distrito está vazio e a maioria do comércio fechado, exclusivamente para a obtenção de dados sobre as festas pesquisadas através de entrevistas com os moradores, pois não foi possível entrevistar vários dos que participam das festas durante o período das mesmas.

Através destas visitas a campo se tornou possível melhor entender a relação de apropriação das festas pelos moradores da comunidade e a relação destas festas e desta comunidade com o turismo.

Assim, este trabalho procurará expor as peculiaridades existentes nesta localidade, em seu povo e em suas festas, fugido de qualquer determinação simplista e maniqueísta, onde se procura uma pureza antimercadológica inexistente no mundo contemporâneo.

\section{1 - As rezadeiras e suas rezas: Como a população de Lavras Novas se} apropria de suas festas.

\subsection{1 - As diferentes relações do povo com as festas e os festivais}

São várias as festas que podem ser observadas na comunidade de Lavras Novas, como a Folia de Reis, Festa do Divino e de Nossa Senhora dos Prazeres, Coroação de Nossa Senhora, Semana Santa, etc. No distrito acontecem também outros eventos, como o festival de queijos e vinhos Safras Novas, criado em 2007, o festival de jazz, o festival de blues. A maioria destes eventos é criada pelas grandes pousada existentes no distrito (todas com proprietários de fora da comunidade), porém, para não ficarem de fora do lucro com a 
grande quantidade de turistas que adentra o distrito, os moradores aderem à programação. Juliana Vieira Viana, trabalha em um restaurante no restaurante $O$ Fuxico, na parte baixa da comunidade, que só abre aos finais de semana, para atender a demanda turística:

"Quando as pousadas lá de cima, as mais ricas, fazem as coisas, organizam coisas, enche de turista aqui. Ainda mais que eles fazem isso mais é em feriado, né? Antes eles faziam as coisas e nem consultavam o pessoal daqui mesmo, o povo daqui de baixo, mas o pessoal não gostou disso não e falou com eles, agora sempre que eles vão fazer alguma coisa eles avisam a irmandade. A gente até que acha bom ter as coisas, porque entra dinheiro, e a gente vive disso." 85

A maioria destes eventos ocorre durante feriados prolongados e finais de semana, todos com o objetivo de atrair turistas à comunidade. O problema é que os impactos ambientais e sócio-culturais, muitas vezes não são medidos. Em 2007, por exemplo, o distrito de Lavras Novas recebeu mais de 5.000 mil turistas durante o festival Safras Novas. Em 2007, primeiro ano do festival, organizado pelas maiores pousadas da região, o evento ocorreu de forma impositiva sobre os moradores da comunidade. $\mathrm{O}$ que pode ser melhor entendido na fala de Suzana Menezes Macedo:

"Eles simplesmente fizeram e pronto. Ainda levaram nossas mulheres daqui para trabalhar lá, seguindo orientações de chefes franceses e tudo. Vieram fazer comida francesa aqui? Em lugar de cultura mineira? E nem falaram nada com o pessoal daqui de baixo, que é o povo da cidade. Ah, mas aí nós ficamos furiosos, e fizemos na mesma época o Festival Safras Velhas. Colocamos barraquinhas com comida mineira, fizemos apresentação de congado, a marujada, né? Organizamos tudo rapidinho e ficou lindo! Fizemos de protesto mesmo. Depois disso eles conversaram com o povo daqui e ficou acordado que não se faz mais nada aqui sem o consentimento da população." ${ }^{, 6}$

Assim, como se pode observar, há uma grande diferença entre as festas religiosas, (organizadas pelo coletivo dos moradores em parceria com os donos de serviços comerciais) e os eventos direcionados aos turistas. Estes últimos nem sequer possuem, de acordo com a conceituação deste trabalho, as características para serem chamados de festa,

\footnotetext{
${ }^{85}$ Fonte: trabalho de campo realizado em 30 de maio de 2010.

${ }^{86}$ Fonte: trabalho de campo realizado em 29 de março de 2010.
} 
pois não rompem com o tempo linear da comunidade através de sua inserção no que é feito durante os mesmos. Pois na festa,

“... mesmo contrariando as práticas intencionalmente concebidas no momento da festa, os usos e costumes mais profundos vivenciados pela cotidianidade, entranhados no inconsciente, afloram, mostrando a verdadeira face de um povo, moldada através da cultura (...) A festa deve ser vista como um conjunto de atos cerimoniais de caráter coletivo, pela sua colocação dentro de um tempo delimitado, visto como "diverso" da cotidianidade." (FERREIRA, 2000: 136)

Já os eventos que são produzidos para os turistas, para a obtenção de lucro, são fragmentados, não se preocupando, necessariamente, com um intercâmbio cultural, com a afirmação da identidade, não possuindo atos cerimoniais. Suzana Menezes Macedo conta que:

"Como eu, apesar de morar aqui há muitos anos, sou de fora, acho que é bem fácil diferenciar os eventos feitos para ganhar dinheiro com turismo, das festas da comunidade. Acho que a resposta já está aí, né? Uns são eventos isolados, onde o povo da cidade trabalha pra ganhar dinheiro, e só, e os outros são festas de verdade, que mobilizam toda a comunidade." ${ }^{87}$

As festas da comunidade, todas de origem afro-católica, são feitas pelo povo e para o povo, possuem um sentido de pertencimento e de identidade para aquela população, um sentido de unidade que se encerra no real sentido do que é uma comunidade, diferentemente do que ocorre com os festivais e eventos, apesar de existirem turistas na comunidade também nos períodos das festas religiosas.

Portanto, a relação da comunidade com suas festas religiosas é totalmente diferente de sua relação com os eventos direcionados unicamente ao turismo. Esta relação se dá de diferente forma devido aos mecanismos que possibilitam e incentivam as mesmas a se encontrarem em âmbitos diferentes: o simbólico e o econômico. Não que estes não possam existir concomitantemente, porém o que se implica nesta distinção é o foco prioritário em que se ancora cada tipo de relação.

Nos eventos direcionados aos turistas, que acontecem nas pousadas, nos barzinhos, nos restaurantes, e que são acompanhados pelas lojas de artesanatos e lembrancinhas

\footnotetext{
${ }^{87}$ Fonte: trabalho de campo realizado em 29 de março de 2010.
} 
abertas todo o dia, a relação da comunidade com seus bens culturais e com os turistas é baseada no consumo. Já nas festas religiosas, organizadas pela população, a relação com os bens simbólicos da comunidade se encontra acima da relação de consumo que existe com o turismo na região, e a relação de troca e de aprendizado acontece mais pela observação no silêncio, no caminhar e no conhecer do que na compra por si só. Essa diferença pode ser melhor entendida pela fala de Alderico Sabino Guimarães:

"Aqui, quando é final de semana e feriado, principalmente, a gente quer trabalhar pra poder ganhar um pouco de dinheiro com turismo, porque aqui durante a semana não tem nada, as coisas nem abrem, raramente tem algum turista aqui. E aqui não tem mais nada né? É um lugar lindo, eu adoro isso daqui, mas as pessoas só vêm no final de semana. Eu mesmo tenho esses chalezinhos aqui que vocês estão, e estou construindo mais dois. Eu e meu irmão mesmo que fazemos tudo. A gente tem que viver de alguma coisa né? $\mathrm{E}$ todo final de semana tem gente, porque a gente aluga barato. $\mathrm{O}$ pessoal todo gosta, né mesmo? Mas época de festa da irmandade é diferente, muitas vezes a gente para com as coisas que tem nos bares, com as músicas por causa das festas da irmandade. Porque aí é outra coisa, né? A pessoa tem que vir e respeitar a festa que é o final de semana é pra ela né? Até tem coisas nos bares, nos restaurantes, mas nada que atrapalhe a festa. Quando tem festa as outras coisas, que não são da festa, são menos e mais tranqüilas. Tipo, mesinha e música no meio da rua não têm." 88

O irmão de Alderico, Luciano Sabino Guimarães, completa:

"É, até que tem coisas na época de festa aqui, porque às vezes coincide de a festa cair e um feriado, como acontece muito na semana santa. Não vou falar que não atrapalha em nada porque atrapalha sim, eu mesmo as vezes tenho que trabalhar no restaurante aqui e não posso ir nas coisas da festa da irmandade. Ai ajudo nas coisas só quando da tempo, ajudo a fazer o tapete. Mas os turistas, na maioria respeitam. Sempre tem um outro que faz alguma coisa, mas ai a gente conversa, repreende, fala que tem que respeitar. Se tiver na casa de algum morador daqui fazendo bagunça a gente até manda embora. Até já aconteceu isso aqui. Mas no geral o povo gosta de ver, de participar, respeita, acha bonito né? Em época de festa da irmandade o negócio é a festa da irmandade, o resto das coisas pra fazer pra turista tem que ser de acordo, pra não atrapalhar." ${ }^{89}$

Apesar de o turismo ser a principal renda da comunidade, existe uma certa restrição aos eventos relacionados ao turismo na comunidade no período em que se realizam as

\footnotetext{
${ }^{88}$ Fonte: trabalho de campo realizado em 01 de abril de 2010.

${ }^{89}$ Fonte: trabalho de campo realizado em 01 de abril de 2010
} 
festas religiosas da comunidade. No feriado de Semana Santa, conforme o citado no capítulo anterior, os bares ficam mais cheios do que durante as outras festas, pois esta ocorre no feriado, portanto se torna necessário tomar medidas para poder conciliar as festividades de Semana Santa e o grande número de turistas que chega à comunidade.

A Festa do Divino e de Nossa Senhora dos Prazeres, por exemplo, se realiza sempre no final de semana mais próximo ao dia 8 de setembro, porém, nunca realizando esta festa juntamente ao feriado de 7 de setembro, justamente para a festa poder ocorrer em uma data em que o distrito tenha uma quantidade menor de turistas.

O senhor Carlos Aurélio de Carvalho afirma que não existe uma interferência direta do turismo não religioso nas festividades de Semana Santa, mas admite que o fato de a quantidade de turistas durante o feriado ser muito maior que nos finais de semana comuns interfere na participação dos lavra-novenses em suas próprias festas:

"É que é o seguinte, quanto mais gente vem pra cá, mais dinheiro entra pra nós, e muita gente vive só disso aqui, né? De turista. Na verdade os turistas não costumam atrapalhar as festas não. As vezes tem um ou outro que faz algazarra, mas, a festa em si não chega a atrapalhar não. O que é ruim é que quando tem muita gente aqui o trabalho dobrado, de todo mundo, de quem trabalha aqui na minha cooperativa pra fazer mais coisas de bambu, de quem trabalha nos restaurantes... em muitos restaurantes daqui de baixo, e mesmo nas pousadas tem que contratar mais gente pra trabalhar. Ai acaba que o povo daqui vira o feriado trabalhando e não pode participar da festa. Vai só em pouca coisa ver, mas participar mesmo, no dia, acaba que não dá. Mais eu como sou velho, e só trabalho aqui na cooperativa, tenho meu horário, eu vou na festa, participo, vou na Semana Santa... tudo." ${ }^{90}$

Suzana Menezes Macedo pondera sobre o assunto:

"É difícil, porque Semana Santa cai sempre no feriado. Na festa de Nossa Senhora dos Prazeres já da pra fugir de feriado. Final de semana normal o número de turistas é mais tranqüilo. Mas, realmente, Semana Santa é uma época complicada, porque tem muita gente vindo pra cá. Muita gente vem pra fazer esporte radical, turismo ecológico, nem sabe da festa. Problema com desrespeito é raro ter aqui. $\mathrm{O}$ turismo acaba atrapalhando porque consome a maioria das pessoas daqui no trabalho. E como que a pessoa não trabalha? Mesmo porque muitos são funcionários. Não tem jeito." 91

\footnotetext{
${ }^{90}$ Fonte: trabalho de campo realizado em 04 de maio de 2010.

${ }^{91}$ Fonte: trabalho de campo realizado em 29 de março de 2010.
} 
Percebendo esta grande diferença entre a relação da cultura da comunidade com os eventos unicamente direcionados ao turismo e sua relação com suas festas religiosas, realizadas pela Irmandade de Nossa Senhora dos Prazeres, se torna necessário definir os principais elementos dentro desta diferenciação, definir seus motivos e a partir disso traçar um discurso mais aprofundado sobre os possíveis rumos para o turismo e para as festas desta comunidade. Para isto este trabalho tomará como pontos importantes, neste caminho, a questão cultural e identitária e a questão econômica, não procurando desatrelar uma da outra (o que seria praticamente impossível), mas sim procurando identificar as diferenças destas relações (comunidade - eventos turísticos X comunidade - Festas) com as diferenças no enfoque de cada uma (Identidade cultural X economia).

\subsection{2 - Queijos, vinhos e Blues: o turismo dos festivais}

Para analisar a questão dos bens culturais da comunidade de Lavras Novas, bem como a influência do turismo, é necessário considerar que este fenômeno vem ocorrendo em diversas comunidades, a nível global. É um fenômeno universal.

Existe uma convergência entre a produção de bens culturais lúdico-artísticos reconhecidos como populares e os sistemas técnicos e empresariais de disseminação de informações e do comércio de símbolos. Esse tipo de parceria, super difundida nos dias de hoje, aparenta ser uma relação simbiótica, enquanto na verdade acaba por ser uma relação de parasitismo por parte dos sistemas de comunicação, e de dependência por parte das culturas populares.

Esta relação de dependência das culturas populares, principalmente das culturas populares subalternas das pequenas comunidades, pode ser explicada através de sua exclusão do processo capitalista neoliberal e da diferença entre as classes dos indivíduos que se inserem nestes dois grupos (informação e comércio $\mathrm{X}$ culturas populares).

"A diferença entre as classes o os grupos sociais não é apenas econômica. Mas é o resultado desta partição diferenciada na reprodução materialsimbólica da sociedade (...) É por isso que a explicação para a apropriação 
desigual dos bens econômicos culturais não está apenas no campo da produção, mas, na realidade do mundo atual...” (FERREIRA, 2006: p.110)

Neste sentido é necessário entender que dentro desta realidade atual, as pequenas comunidades são os principais focos da indústria do turismo em parceria com a mídia incentivadora, justamente por se tornarem vulneráveis perante ao capitalismo, necessitando adentrar este sistema para poderem garantir sua continuidade.

Dessa forma, várias localidades, como é o caso de Lavras Novas, passaram a receber o turismo como uma solução para seus problemas econômicos e de saneamento, o que muitas vezes procede, a questão é a forma como este processo acontece.

No caso de Lavras Novas, em que se considera uma grande diferença entre os eventos direcionados aos turistas e as festas populares subalternas da comunidade, as análises seguem primeiramente sobre a forma como a comunidade trata o turismo propriamente dito, as atividades direcionadas unicamente ao turismo, que se enquadram na forma de expansão da produção capitalista dentro das pequenas comunidades.

Em Lavras Novas é comum encontrar um tipo de "programação cultural" que parece seguir uma espécie de padrão em várias pequenas comunidades: MPB sendo tocada nos bares, shows de piano e violino nos restaurantes, músicas ambiente que seguem os modelos elitistas, ditos eruditos, tocando nas lojas e pousadas, sem contar que nas grandes pousadas da comunidade encontram-se os mais variados cardápios, com variações de comida portuguesa, italiana, japonesa e até francesa.

Essa padronização do turismo, que se dá em diversas localidades, privilegia o gosto mediano dos turistas, procurando adaptar a localidade, sua gente e sua cultura a ele. Assim a comunidade acaba muitas vezes banindo sua cultura original para se adequar ao gosto desses turistas.

Em Lavras Novas, durante os finais de semana e os feriados, a comunidade toda se mobiliza para receber os turistas, que chegam de todos as partes do país e do mundo. Os estabelecimentos comerciais todos funcionam somente nestes períodos (exceto dois mercados que ficam abertos durante toda a semana e que servem também à comunidade local). Em praticamente em todas as grandes pousadas, em todos os bares e restaurantes é oferecida uma "programação cultural", como meio de atrair o maior número de turistas possível. Porém, em nenhum dos bares, pousadas ou restaurantes nos quais a pesquisa de 
campo foi feita, a programação cultural era compatível com a cultura local. A visita a estes estabelecimentos se deu de forma espontânea, durante os períodos de permanência no distrito (exceto nos períodos em que foram observadas as duas festividades estudadas). Portanto as datas em que os estabelecimentos comerciais dedicados ao turismo foram visitados foram as mesmas em que foram realizadas as visitas a campo, citadas no início deste capítulo.

O bar O Fuxico, no início da rua principal de Lavras Novas, é um dos bares mais frequientados de Lavras Novas, pois tem preços populares e oferece shows à tarde e a noite. Os shows são, quase sempre, de MPB, com voz e violão, na maioria das vezes com artistas trazidos de Ouro Preto, ou mesmo de outras cidades, como Belo Horizonte. Alexandra Costa, dona do estabelecimento, é natural de Belo Horizonte. Ela e o marido começaram a viajar para Lavras Novas logo no início da transformação do distrito em pólo turístico, com o passar do tempo resolveram montar um bar na comunidade, o qual começou a funcionar em 1995. Ao ser indagada do motivo pelo qual o bar privilegia artistas de fora aos nativos da comunidade para apresentações artísticas, Alexandra respondeu:

\begin{abstract}
“Algumas vezes a Banda Quilombo ${ }^{92}$ vem tocar aqui, mas é só por pouco tempo. Na verdade os turistas que freqüentam aqui o local querem mais é tomar uma cervejinha sossegados ouvindo uma boa música. Faço parceria com o pessoal daqui da comunidade sim, mas é que não dá pra por muito tempo. Eu gosto muito do povo daqui, os 4 funcionários aqui do bar são da comunidade." 93
\end{abstract}

Apesar de a maioria dos shows apresentados no Fuxico serem com músicas e artistas que não pertencem à comunidade, a comida servida no bar inclui variados petiscos e bebidas típicas da culinária mineira, como o pastel de angu, o torresmo e os caldos de feijão e de couve, preparados por mulheres da comunidade empregadas no bar de Alexandra. Além disso a localização do bar $O$ Fuxico, no início da rua principal da comunidade, facilita uma observação mais próxima da vida dos moradores.

\footnotetext{
${ }^{92}$ A Banda Quilombo é uma banda local formada por senhores. Era bastante conhecida no início da década de 90, quando fazia apresentações em vários restaurantes e bares de Lavras Novas. O repertório da banda passava pelo forró, samba e congado. A banda ainda existe, mas hoje tem pouca visibilidade na comunidade, tendo apresentações esparsas.

${ }^{93}$ Fonte: trabalho de campo realizado em 12 de setembro de 2009.
} 
Na pousada e restaurante Carumbé ${ }^{94}$, situada na entrada do distrito, e que é um das mais caras presentes na localidade, a relação com a cultura popular da comunidade é ainda mais distante. Inclusive, em seu site ${ }^{95}$, a pousada faz questão de frisar que se encontra longe da população e de barulhos, tratando esse aspecto como ponto positivo. Além da decoração incompatível com a cultura do local onde se encontra, a pousada ainda tem como especialidade as cozinhas italiana e francesa, possuindo poucos pratos típicos de Minas Gerais. Os shows se delimitam a MPB, blues e jazz, em nenhum momento remetendo às origens culturais da comunidade.

A relação da Pousada e Restaurante Carumbé com a comunidade e sua cultura serve para ilustrar o tipo de relação mais comum das pousadas e restaurantes mais requintados com a cultura popular da comunidade de Lavras Novas: Uma relação de simples uso do patrimônio material, da localidade, desprezando o patrimônio imaterial.

Dentre as grandes pousadas da região podemos citar também a Pousada e Restaurante Kokopelli, que sempre promove shows de artistas de fora da comunidade ou dispõe de jazz ou blues como música ambiente.

Todas estas grandes pousadas são de propriedade de pessoas de outros locais do país, nenhum morador da comunidade é dono de uma grande pousada ou restaurante na comunidade. São estas grandes pousadas e restaurantes as responsáveis pela criação de festivais e eventos que tem como único intuito promover o turismo gerador de lucros. Essas pousadas se unem para criarem muitos destes eventos, como foi o caso do festival de queijos e vinhos Safras Novas, o Lavras Blues e outros eventos esporádicos nos finais de semana.

Fora as grandes pousadas, que se instalam em Lavras Novas, unicamente para aproveitarem-se das belezas naturais, existem restaurantes, pousadas e chalés mais simples, todos próximos à rua principal da cidade, cujos donos são naturais de Lavras Novas. Esses novos estabelecimentos comerciais surgiram para procurar concorrer com as grandes pousadas, para que os moradores também pudessem usufruir sua própria terra, sem precisarem ser funcionários. É o caso do restaurante e dos chalés de Seu Domingos Lessa:

\footnotetext{
${ }^{94}$ Carumbé é o nome que se dava às bacias usadas para lavar ouro na região no período de mineração.

${ }^{95} \mathrm{O}$ site da Pousada e Restaurante Carumbé é: www.carumbe.com.br/site/lavrasnovas/index.php.
} 
"Na verdade eu criei isso daqui faz tempo. Esse restaurante começou na cozinha da casa de minha mulher. Tava começando a vir gente pra cá e faltava lugar pra comer, uma comidinha, assim... de casa, né? Ai a gente começou a cobrar uns troquinhos pros viajantes comerem aqui. Com o tempo o número de gente foi aumentando e a gente acabou abrindo um restaurante. Eu já reformei isso daqui, depois fiz uns chalezinhos aí nos fundos. Tudo com precinho bom. Precisei fazer, né? Se a gente não faz os donos lá de cima ${ }^{96}$ ficam aqui na nossa terra ganhando nosso dinheiro e nós aqui de baixo sem nada." 97

O que aconteceu em Lavras Novas foi uma forçosa adaptação dos moradores em relação ao grande número de turistas, uma adaptação inclusive em seu modo de produzir, para poder atender a constante demanda.

Em restaurantes e pousadas como a do Seu Domingos pode-se notar uma grande diferença em relação às pousadas mais requintadas: Apesar de as músicas ambiente quase sempre seguirem o padrão da MPB, a relação com a comunidade é mais direta, apresentando a cultura do local não através de eventos e apresentações, mas sim com o contato direto com os moradores da comunidade. Quem se hospeda em um quarto na casa de nativos, por exemplo, pode conhecer mais de perto a cultura do povo.

Nos pequenos restaurantes, alguns até situados dentro das cozinhas da casa das pessoas, é comum a indicação para conhecer a casa de cultura Dedela, coordenada por Suzana Menezes Macedo. Na casa de cultura pode-se conhecer o grupo Nananã, que faz ensaios e apresentações de marujada, é comum também ouvir diferentes versões sobre a formação de Lavras Novas contada pelos moradores mais velhos, ouvindo também muitos contos e lendas sobre o lugar.

Nos restaurantes menores e nos pequenos bares é comum ouvir-se MPB, músicas lentas ou mesmo as músicas que fazem sucesso na mídia. Porém, seria purismo nomear estes elementos como descaracterização cultural, visto que as culturas populares não se esgotam em vitrines a serem admiradas, seus elementos também estão inseridos no sistema capitalista de produção, sendo influenciados pela mídia e pelos padrões sistêmicos globalizados e impositores, assim como acontece com qualquer cultura popular subalterna ocidental, hoje.

\footnotetext{
${ }^{96}$ Quando Seu Domingos Lesssa fala em donos lá de cima refere-se aos donos das grandes pousadas, que ficam na parte alta, logo na entrada da cidade.

${ }^{97}$ Fonte: trabalho de campo realizado em 03 de maio de 2010.
} 
Assim a realidade de Lavras Novas em relação aos turistas se torna ambígua: de um lado as grandes pousadas que incentivam cada vez mais o turismo predatório, e de outro os serviços oferecidos pelos moradores da comunidade, mais simples, porém mais próximo de um turismo emancipador. Segundo D. Vera Lessa:

"Tem muito turista que vem pra cá e nem chega aqui na parte de baixo, vem um dia ou outro, tira foto e volta pra dentro da pousada. Também, essas pousadas tem tudo lá dentro né? Tudo. O bom é que o pessoal pelo menos não faz bagunça e não atrapalha nada aqui. Não incomoda. Tem outras vezes, em feriado, que tem gente que vem pra cá só pra badernar, ai fica nas casas da gente mesmo, em pousadas daqui de baixo. Mas se tiver atrapalhando os moradores vão lá e conversam, pedem pra parar com a bagunça na cidade dos outros. Se não adiantar o povo põe pra correr daqui, manda embora mesmo. Tem pouco isso aqui hoje, mas já aconteceu." ${ }^{98}$

Com o aumento exacerbado do turismo, devido ao incentivo midiático e mesmo devido à grande publicidade de eventos produzidos pelas pousadas de alto padrão. Lavras Novas se tornou um pólo turístico, cujos moradores não tiveram a oportunidade de planejar o crescimento turístico, ou mesmo de deixar com que o aumento da infra-estrutura ocorresse de modo espontâneo.

As grandes pousadas trouxeram um número de turistas além do suportado pela comunidade, trouxeram eventos incompatíveis com a cultura local, se apropriaram unicamente das belezas naturais do distrito e transformaram os verdadeiros donos do patrimônio material e imaterial em assalariados.

É muito comum os indivíduos naturais de Lavras Novas serem empregados de restaurantes, pousadas e lojas de artesanato, cujos donos não fazem parte da comunidade, são de outras cidades ou mesmo de outros estados.

O turismo em Lavras Novas se iniciou com o turismo cultural e de aventura, ocorrendo de forma esporádica e sem a criação de grandes aglomerações aos finais de semana e mesmo nos feriados. O turismo crescia em um ritmo lento até a década de 1980, afirma Seu Domingos Lessa:

"Ah! Antes não ia aumentando o povo assim não. Vinha gente pra cá nos anos 80 , já vinha aumentando o número de gente, mas a gente recebia em

\footnotetext{
${ }^{98}$ Fonte: trabalho de campo realizado em 01 de abril de 2010.
} 
quartos em casa mesmo. Ia fazendo chalezinhos aos poucos, ia montando os restaurantes e as lojinhas improvisados e depois aos poucos ajeitando. Depois construíram essas pousadas enormes aí... começou a sair coisa daqui em jornal, em televisão, aí qualquer coisinha enchia de gente, mas é bom né?" 99

Ao ser indagado sobre os prós e os contras do aumento rápido do turismo na comunidade, principalmente a partir da década de 1990, Seu Domingos conta:

"Eu digo que é bom porque traz dinheiro pra comunidade, aqui antes era muito pobre. Melhorou muito. O ruim foi que do jeito que cresceu o povo mesmo não teve jeito de acompanhar. As pousadas lá de cima e o aparecimento daqui em tudo quanto é jornal e revista trouxeram gente de mais de uma vez. Se tivesse sido do jeito que estava sendo o próprio povo daqui podia ser dono das coisas, criar os eventos, as coisas pra trazer gente. Isso do jeito nosso aqui. Quem não gostasse não vinha, uai. (risos)" 100

Suzana Menezes Macedo completa:

"Acabou que o povo de fora virou dono das coisas aqui, e o povo daqui empregado. Lógico, né? O povo daqui não tinha dinheiro pra abrir pousadas e restaurante do tipo dos que começaram a surgir no início da década de 90. Acabou que o povo daqui teve que se adaptar: hoje são donos de várias coisas, fazem vários eventos, e tem força mesmo para impedir de essas pousadas grandes fazerem algum evento que o povo não queira. Hoje em dia a maioria das coisas são discutidas na associação de moradores ou mesmo na Irmandade Nossa Senhora dos Prazeres. O povo daqui tá aprendendo a largar de ser bobo." 101

Em Lavras Novas, hoje, existem vários estabelecimentos pertencentes a nativos, como restaurantes, pousadas, lojas de roupas e artesanato, bem como chalés para aluguel, na maioria das vezes construído pelos próprios moradores, nos terrenos da casa onde moram.

Assim, a população de Lavras Novas, que vinha se acostumando com a chegada do turismo à sua comunidade desde o início da década de 1980, se deparou com um aumento abrupto deste na década de 1990. Com o crescimento sem planejamento por parte da

\footnotetext{
${ }^{99}$ Fonte: trabalho de campo realizado em 03 de maio de 2010.

${ }^{100}$ Fonte: trabalho de campo realizado em 03 de maio de 2010.

${ }^{101}$ Fonte: trabalho de campo realizado em 29 de março de 2010.
} 
população local, em um primeiro momento, a comunidade se tornou vulnerável à imposição dos grandes estabelecimentos comerciais que se empreenderam no local, trazendo visibilidade e trabalho assalariado.

Porém, em um segundo momento, que se pode tratar como atual, a comunidade começa a fazer valer seus princípios e sua tradição, não aceitando mais imposições sobre as realizações de eventos, e procurando desenvolver-se para atender a demanda turística fora dos domínios das grandes pousadas e restaurantes. Hoje, os eventos desenvolvidos pelas pousadas, os shows nos bares e restaurantes, têm de ser discutidos juntamente a associação de moradores e os possíveis impactos analisados. A comunidade de Lavras Novas sentiu o peso de um turismo desordenado e sem planejamento e está procurando, aos poucos, organizar as atividades turísticas. Como pode ser observado através da fala de Itamar de Carvalho, natural de Lavras Novas, 26 anos, que concluiu o curso técnico de turismo em Ouro Preto:

"Agora a comunidade está se organizando mais. Não só para as festas
religiosas, mas pra tudo, pra desenvolver o turismo. Aqui a gente (a gente
que eu digo é o povo daqui de baixo, mais pobre, que nasceu aqui mesmo)
está começando a mudar as coisas. Mas agora é mais em relação à
organização das coisas que tem aqui, de organizar as coisas, de colocar
regras para o funcionamento dos bares, colocar hora pra acabar música alta,
de... ir falar com turista que está fazendo arruaça, combinar as coisas com
as pousadas antes de fazer... essas coisas, né? E até que tem dado certo,
mas ainda tem muita coisa pra fazer." 102

No turismo não religioso, a maior preocupação ainda é o lucro, como na grande maioria das regiões onde esta atividade se desenvolve. O lucro obtido através das atividades do ramo do turismo não se adequam a comunidade, mas sim a comunidade adequa-se a elas. Com um início nestes moldes, Lavras Novas procura soluções para conciliar os eventos turísticos e seu modo de vida, de maneira a gerar menores impactos.

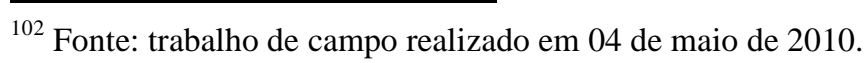




\subsection{3 - Santos e pagãos: o turismo religioso e suas peculiaridades}

Ao pronunciar a expressão "turismo religioso", coloca-se em contanto duas dimensões aparentemente opostas: uma atitude de lazer, descompromissada, desterritorializada, e outra atitude de fé, relacionada à identidade, a ritos, a valores. Contudo, na atual configuração do campo religioso no Brasil não se pode tomar a religião como dotada de uma substância imutável, refratária a atitudes de lazer e divertimento. (Silveira, 2003: 42).

Neste trabalho não se pretende colocar turismo e religião em antagonismo, pelo campo da religião se situar na esfera mágica e simbólica. A procura pela esfera identitária, mágica e simbólica se torna uma das possibilidades para a diminuição dos elementos predatórios nas pequenas comunidades.

Dessa forma, o turismo religioso a que esta pesquisa se refere, na comunidade de Lavras Novas, vai além do turismo das romarias e peregrinações, encontrando na fé, um denominador comum entre comunidade e turista, onde não é necessária a imposição de regras, nem o trabalho servil do morador para com o turista, mas sim, onde o que predomina é a interação no campo simbólico.

Assim, em Lavras Novas, o turismo durante as festas religiosas se diferencia dos demais tipos de turismo (inclusos no que foi explicitado no tópico anterior) por não apresentar como foco primordial a obtenção de lucro, apesar de o consumo estar presente também nestes períodos.

O turismo religioso necessita de um enfoque diferenciado, justamente por não apresentar um produto material consumível (por mais que se criem produtos, para a venda, atrelados às festas religiosas) e por ele estar composto por um tipo diferente de turista.

O turista religioso não procura simplesmente lazer, mas sim cultivar sua fé, sua devoção, procura algo que vai além dos bens e prazeres materiais, portanto este tipo de turista procura a afirmação de sua visita a certa localidade pelo valor imaterial intrínseco a ele através de sua cultura e de sua tradição.

A maioria dos turistas que vão até a comunidade interessados nas festividades religiosas são turistas provenientes, em sua maioria, dos outros distritos de Ouro Preto que ficam próximo a Lavras Novas, como: Cachoeira do Campo, Aramantina, São Bartolomeu, 
Santo Antônio do Salto, Santo Antônio do Leite, Santa Rita, etc. Entre estes distritos de Ouro Preto, incluindo o de Lavras Novas, acontece uma espécie de reciprocidade nas visitas aos eventos religiosos.

Por apresentarem uma formação histórica parecida, e uma inter-relação desde os tempos da colônia, todas estas comunidades apresentam uma forte religiosidade, com festas religiosas tradicionais. É comum a irmandade de um distrito organizar viagens para participar de festas organizadas pela irmandade de outros distritos. Como se pode observar na fala de D. Prosperina Lessa Viana:

“A gente organizava muita ida na festa de São Sebastião, na festa de São Benedito de Santo Antônio, tudo aqui pelas redondezas. É muito bonito. Eu ia bem mais, agora só vou de vez em quando porque a idade já cansa, né? Mas, assim, vem muita gente daqui dos distritos perto pras festas daqui de Lavras Novas. Vem gente de Santo Antônio do Salto, de Santo Antônio do Leite, da Chapada, você precisa ver. Esse pessoal vem participar da festa mesmo e a maioria acaba ficando na casa do pessoal daqui. Aqui em casa mesmo sempre fica gente. Aí quando o povo daqui vai p lá, pra outro lugar, na festa, também fica na casa do povo de lá. E é bom ... muito bom." 103

É interessante notar que entre os distritos de Ouro Preto existe muita consangüinidade. D. Prosperina conta que:

"Tem Lessa lá, tem Lessa aqui. Os Vieira também tem em Santo Antônio do Salto. Tem gente que é parente mesmo, mas tem gente que tem o mesmo sobrenome e nem sabe se é parente, não. Deve ser, não é mesmo? Deve ser tudo o mesmo povo que veio pra cá há muitos anos e foi se esparramando. Sei que parente ou não parente nós somos todos irmãos perante Nossa Senhora dos Prazeres e a luz divina." 104

Durante as festas religiosas da comunidade os turistas vindos de outros distritos da cidade de Ouro Preto participam atentos, acompanhando as procissões, as rezas e até mesmo tendo idéias para as próximas festas em suas comunidades. Seu João Maia veio de Santo Antônio do Salto,e trouxe toda a família, para as celebrações de Semana Santa em Lavras Novas:

\footnotetext{
${ }^{103}$ Fonte: trabalho de campo realizado em 20 de março de 2010.

104 Fonte: trabalho de campo realizado em 29 de março de 2010.
} 
"A festa de Semana Santa aqui é muito bonita. Se eu pudesse eu participava de tudo, mas só dá pra vir mais no fim da semana. A gente vem na festa, vai na procissão, canta. Sai pra dar umas voltas também, conversar com os amigos (...) Eu fico na cãs de um compadre meu há muitos anos. Eles também vão pra lá na Festa de Santo Antônio, que também é muito bonita. A gente vem pra cá, copia umas idéias, eles vão pra lá e copiam também (risos). Nessa as festas vão ficando cada vez mais bonitas." 105

Como se pode perceber na fala de Seu João e de D. Prosperina, o turismo feito por quem visita a comunidade no intuito de participar de suas festas, pode ajudar a enriquecer a cultura popular do local, colaborar com a afirmação da identidade da comunidade, causando impactos menores sobre os valores simbólicos locais. Este tipo de turismo pode facilitar a ocorrência de trocas simbólicas que ajudam a resgatar a própria identidade da comunidade, este resgate, porém, pode, algumas vezes, significar a incorporação constante de novos valores aos tradicionais. Ferreira afirma:

“... este conflito, longe de ser algo prejudicial, é uma experiência salutar, porque esta renovação, dialeticamente, enriquece a identidade cultural da comunidade, pois ao incorporar novos valores culturais atesta o caráter cumulativo e dinâmico da experiência humana na construção da cultura." (Ferreira, 2006: 64)

Este tipo de turista não cria demandas que imponham à comunidade o desenvolvimento de atividades que fujam aos seus gostos e valores tradicionais. A infraestrutura da qual este turista precisa já está presente naturalmente na comunidade, porém, analisando por outro ângulo, este tipo de turista pouco incrementa a economia local.

Alguns turistas de outras localidades também vão para Lavras Novas para acompanhar as festas, porém em menor quantidade. Estes geralmente são provenientes de Ouro Preto e Belo Horizonte. Marta Silva Sena, de 60 anos, é de Belo Horizonte e diz que sempre vem a Lavras Novas durante a Festa do Divino por ser muito devota:

"Eu venho pra cá acompanhar a festa mesmo. Até aproveito pra comer em um lugar gostoso, pra dar umas voltas, mas meu interesse mesmo é a festa. Eu sou muito devota, sabe? Consegui muitas bênçãos pedindo ao Divino. A festa daqui é diferente de tudo que eu já tinha visto, o povo tem uma fé!

\footnotetext{
${ }^{105}$ Fonte: trabalho de campo realizado em 03 de abril de 2010.
} 
Desde que vim pela primeira vez não parei de vir mais. Agora já vou indo que ainda tenho que tomar banho pra ir pra missa (risos)." 106

Assim como Marta, turistas de outras localidades também se deslocam até Lavras Novas para participar e apreciar as festividades. Mesmo que em menor número, estes fazem girar a economia local, se hospedando em chalés ou em quartos alugados por moradores e consumindo na comunidade.

Porém, Lavras Novas, durante as festas religiosas, não recebe somente os turistas que vão para participar das festas, recebe também turistas interessados em apenas desfrutar as belas vistas da localidade, em fazer ecoturismo, em desfrutar da infra-estrutura das grandes pousadas ou da boa comida oferecida nos restaurantes lavra-novenses.

Como as festas religiosas são realizadas sempre nos finais de semana e ainda algumas datas de festas caem em períodos de feriado (Semana Santa e Dia de Finados), no período das festas a comunidade acaba recebendo 2 tipos distintos de turistas: os que praticam turismo religioso, e os interessados unicamente em atividades de lazer. D. Lídia Ribeiro de Carvalho conta:

"Nos tempos de festa vem muita gente pra festa mesmo, mas tem muita gente que vem pra aproveitar o lugar, beber, ouvir música, andar nas pedras daqui, ir nas cachoeiras, e que não quer ir na festa, esse povo não está interessado. Problema deles, né? Não atrapalhando já está louco de bom (risos)." 107

Durante os finais de semana festivos, a comunidade consegue conciliar melhor as festas religiosas e a recepção aos turistas, mas nem sempre foi assim. Itamar de Carvalho afirma que assim que o distrito começou a receber um fluxo constante e grande de turistas, muitos moradores ficaram deslumbrados com as possibilidades de lucro e deixaram a organização e participação nas festas religiosas de lado:

"Eu ainda era menino quando isso começou a encher mesmo. Eu via muita gente deixando de ir nas festas nossas aqui, festas que fazem parte da gente, pra poder montar negócio improvisado pra ganhar dinheiro em final de semana. A gente ouvia o povo comentar também, né? Que tal coisa não tinha ficado boa porque não sei quem não queria ajudar, outro não podia,

\footnotetext{
${ }^{106}$ Fonte: trabalho de campo realizado em 11 de setembro de 2009.

${ }^{107}$ Fonte: trabalho de campo realizado em 12 de setembro de 2009.
} 
essas coisas. Ainda bem que isso mudou. Depois as coisas se ajeitaram. Acho que naquela época tava tudo começando, devia de ser por isso. E aqui era bem mais pobre. Esta todo mundo precisando de dinheiro de verdade" 108

D. Lídia completa:

“Ah! Teve mesmo. Teve uns anos aí, mas já faz uns 20 anos já, que as festas ficaram a deus dará. Tava todo mundo preocupado em montar sua coisa, em ganhar o seu, e as festas ficaram mais ou menos. Aí eu falei lá na mesa administrativa da irmandade pra eles fazerem alguma coisa, eu e a Efigênia. Nas reuniões da irmandade isso foi falado e acho que o povo tomou tento, né? Viu que estava fazendo coisa errada. Mas isso durou uns 2, 3 anos no máximo, esse desleixo. Mas depois voltou tudo de novo a fazer direitinho." 109

A comunidade já criou várias formas para conciliar o trabalho com a recepção dos turistas e a organização e participação nas festas, dentre elas está o revezamento de pessoas da família na participação dos eventos festivos, quando esta família possui um estabelecimento comercial.

Outra medida tomada pela população local para que o turismo não interfira na realização das festas é a não-produção de eventos concomitantes a ela, ou seja, no mesmo final de semana, pois a divulgação atrai um número de turistas muito grande, o que pode colocar em risco a participação efetiva dos lavra-novenses em suas festas.

A comunidade decidiu, dentro da associação de moradores, juntamente a Mesa Administrativa da Irmandade de Nossa Senhora dos Prazeres, que seria necessária uma reunião entre os moradores e todos os donos de estabelecimentos comerciais existentes dentro da comunidade, visando estabelecer limites para a realização de eventos e a criação de regras para os mesmos, dos mais simples aos mais complexos.

Segundo Jessi, presidente da Mesa Administrativa da Irmandade de Nossa Senhora dos Prazeres, uma conversa séria entre a irmandade, moradores e empreendedores se fez inadiável após a realização arbitrária (pelas grandes pousadas) do Festival de Queijo e Vinhos Safras Novas, o qual foi questionado pelos moradores através do Festival Safras

\footnotetext{
${ }^{108}$ Fonte: trabalho de campo realizado em 04 de maio de 2010.

${ }^{109}$ Fonte: trabalho de campo realizado em 12 de setembro de 2009.
} 
Velhas. Segundo Jessi, esta conversa ocorreu ainda em 2007, ano de realização do Safras Novas, e surtiu muito bons efeitos.

"Foi muito bom ter posto todo mundo pra conversar, os moradores reclamaram e os donos das pousadas ouviram. Teve até uma coisa ou outra que eles não queriam acatar, mas tiveram que acatar, porque a cidade é da gente. Por exemplo, a gente exigiu que fosse consultado antes de fazer eventos aqui, que fossem combinadas as coisas em conjunto e que não queríamos que fizesse coisa em final de semana de festa da irmandade. Eles tentaram não querer, mas tiveram que aceitar, mesmo porque a gente explicou os motivos da gente. As vezes tem um problema ou outro, mas coisa simples. O bom é que as coisas estão andando." 110

Dentre as exigências da população com os estabelecimentos comerciais, como bares e restaurantes, estão a de não fazer shows e nem colocar mesas e cadeiras ao ar livre depois das $22 \mathrm{~h}$; e mesmo em locais fechados, manter o som até, no máximo $3 \mathrm{~h}$, em volume que não incomode as casas vizinhas. Nos períodos de festa religiosa as regras ficam mais severas: os bares não colocam mesinhas ao ar livre em nenhum horário, a música ao vivo que ocorre todas as tardes de final de semana é suspensa ou então levada para dentro de ambientes fechados, com som mais baixo.

Em relação às casas alugadas a grupos de turistas por moradores, o dono da casa alugada fica encarregado por alertar os turistas sobre as regras de convivência na comunidade e também, se em época de festa, pedir que o turista respeite as celebrações ligadas à festa. Caso haja barulho incômodo na residência, ou mesmo na rua, os moradores deverão chegar e conversar com os turistas.

Questões relacionadas ao meio ambiente também são pensadas, placas e cartazes são facilmente encontrados nos estabelecimentos comerciais da comunidade, a fim de conscientizar o turista sobre sua responsabilidade com o meio ambiente. Rafael Ribeiro, de 30 anos, é guia e trabalha com ecoturismo:

"Já teve caso de a gente ver gente jogando coisas na cachoeira, de a gente ver gente fazendo churrasco e largando coisas, aí a gente fala mesmo. Tem que chegar numa boa, conversando... geralmente os turistas não acham ruim não, escutam. Mas uma vez ou outra aparece um invocado. Uma vez a

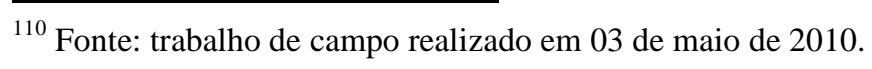


gente já colocou um grupinho aí pra correr. Destruir a cidade dos outros? Aí não, né?" 111

Durante as festas populares da comunidade os cuidados são ainda maiores, para que não se interfira em nada da realização da festa. Como a quantidade de turistas aos finais de semana comuns é moderada, com a colaboração de todos os segmentos da sociedade se tornou mais fácil conciliar turismo e festas religiosas. Na maioria dos finais de semana de festa, são colocados cartazes avisando sobre os horários das procissões, dos eventos e das missas, convidando o turista a conhecer um pouco mais sobre a cultura da comunidade e pedindo ao turista que respeite a festa.

Segundo D. Lurdes as medidas tomadas pela comunidade têm dado certo. De acordo com ela, quase não existem problema com os turistas em finais de semana, principalmente no das festas.

“.... É difícil ter problema com turista aqui. As vezes te problema porque eles alugam casa e fazem festa até tarde, porque fazem algazarra na rua, mas é pouco. O povo daqui fala e eles param. Em época de festa a gente exige respeito maior, mas o povo respeita sim. É difícil ter problema com isso. Depois que não tem mais outras coisas no mesmo final de semana de festa, não tem música alta em bar, e essas coisas, né? Até que resolveu." 112

Mas, nem todas as festas religiosas de Lavras Novas caem no final de semana, algumas são, necessariamente, comemoradas em feriados. Nestes casos muitos moradores reclamam que a quantidade de turistas é muito grande, e que isso atrapalha a organização e execução das festas. É o caso da Semana Santa e do Dia de Finados, por exemplo.

A quantidade de turistas em feriados prolongados é tão maior que nos finais de semana normais, que são chamados vários empregados extras nas pousadas, nas lojas, nos bares e restaurantes. Lavras Novas chega a receber cerca de 5 mil turistas em alguns feriado, como já citado no capítulo anterior. Na maior parte do tempo a maioria dos moradores está trabalhando e acaba não podendo participar dos eventos festivos.

Assim, a população do distrito se preocupa em encontrar uma forma de conciliar sua participação na festividade e os serviços prestados aos turistas, que gera lucros à

\footnotetext{
${ }^{111}$ Fonte: trabalho de campo realizado em 04 de maio de 2010.

${ }^{112}$ Fonte: trabalho de campo realizado em 13 de setembro de 2009.
} 
comunidade. Como a maioria dos habitantes de Lavras Novas possui um negócio familiar, como suítes para alugar no quintal de suas casas, restaurantes de comida caseira, lojas de lembrancinhas ou artesanato, ou trabalham na área de comércio ou serviços relacionados ao turismo, muitas vezes acabam participando somente com apoio financeiro para a realização da Semana Santa, pois não conseguem estar presentes de forma efetiva. Luciano Sabino Guimarães confirma:

“... participo, agora, com contribuição em dinheiro pra poder fazer a festa, essas coisas assim, ou enfeitando a rua de madrugada, quando já larguei o serviço. Mas já participei muito, fui guarda romano, essas coisas, mais agora, por enquanto, não dá porque trabalho a noite, ai não dá para acompanhar a procissão, muito difícil pra mim. Tem gente de mais nos restaurantes, nos bares, nas lojas. Ano que vem, se Deus quiser, vou me empenhar mais..." 113

Alderico Sabino Guimarães acrescenta ainda a fala do irmão dizendo que:

“... a tradição da cidade mudou sim, porque antes todo mundo podia participar, quando não tinha o turismo, quando ele não era forte, hoje as pessoas aqui, mexem com o turismo, muitas pessoas ficam presas em casa, e não podem participar por causa disso, têm que tomar conta das pousadas, de suas casas. Festa que cai assim no feriado é complicado. Se cai em um final de semana normal ainda é mais tranqüilo, tem turista, mas é em quantidade normal, mas em feriado é realmente muito cheio isso aqui, não dá, se não vira uma bagunça só." 114

Nos feriados, são poucos os visitantes que vão à comunidade para participar da cerimônia. Durante a procissão, as rezas, a maioria está nos bares cantando, ou nos restaurantes. Alguns até colocam som alto nas casas alugadas ou nos carros. Outros bebem e cantam no meio da rua. Os lavra-novenses procuram conversar com os turistas que façam esse tipo de coisa, porém, como a quantidade de pessoas na comunidade é muito grande nesses períodos, as programações dos bares e restaurantes extensas, e a maioria dos moradores está trabalhando, fica difícil controlar. Jessi conta que :

"É gente de mais aqui em feriado, aí ainda junta com período de festa, é lógico que a festa sai prejudicada. A gente vive do turismo aqui, não tem

\footnotetext{
${ }^{113}$ Fonte: trabalho de campo realizado em 01 de abril de 2010.

${ }^{114}$ Fonte: trabalho de campo realizado em 01 de abril de 2010.
} 
como. O problema mesmo é nas épocas de feriado, não estamos tendo como controlar. Tem gente bêbada que destrói as coisas da cidade. É complicado. O negócio é controlar o número de pessoas que entra na cidade nesses períodos, mas quem tem bar, quem tem loja, não quer porque acha que perde dinheiro. Aí complica, que que vai fazer?" 115

Outro fato, que chama a atenção acontece na madrugada do Sábado Santo para o Domingo de Ressurreição, durante a Semana Santa, no qual a tapeçaria de artesanato feita na rua é ainda um pouco desrespeitada pelos turistas. Pois durante a noite, anteriormente a produção do tapete, são colocadas notificações nos carros, e distribuídos para as pessoas informativos com o horário que não se pode transitar de carro pela cidade. Mesmo assim esta regra ainda é desrespeitada, fazendo com que o tapete seja, muitas vezes, danificado antes da procissão.

D. Lurdes diz que até a forma de enfeitar a rua para as festas mudou, nas épocas de feriado:

"Antes as ruas todas ficavam enfeitadas, tinha bandeirinha por todo lado,
enfeite com corte de pano, bambu, mas ... agora já não fica tudo enfeitado
como era antigamente. Não tem jeito, como que enfeita? Tem muita gente
na cidade, e não dá nem tempo de fazer as coisas com o povo trabalhando.
Antigamente enfeitava bem mais. Semana Santa era muito mais enfeitado."
116

Segundo Jessi, o povo está começando a perceber que é preciso controlar a entrada de turistas durante os feriados, principalmente durante os feriados festivos. Até mesmo os donos de estabelecimentos comerciais estão começando a achar essa medida necessária, exceto os donos das grandes pousadas. "Acredito que dentro de 1 ou 2 anos a gente já consiga votar a favor disso", afirma Jessi.

Como se pode observar, a apropriação das festas pelos moradores de Lavras Novas acontece de diferentes formas, condicionada a forma como o turismo se dá em diferentes períodos do ano. A população está encontrando um equilíbrio entre o turismo como atividade econômica e a atividade religiosa da população, durante os finais de semana

\footnotetext{
${ }^{115}$ Fonte: trabalho de campo realizado em 3 de maio de 2010.

${ }^{116}$ Fonte: trabalho de campo realizado em 02 de abril de 2010.
} 
festivos, e para isso viu necessário elencar prioridades e criar regras para reduzir os impactos. 


\section{CONSIDERAÇÕES FINAIS}

De acordo com os resultados obtidos através da pesquisa de campo, e com as análises já feitas durante o trabalho, se torna possível entender os mecanismos atrelados à mídia e ao turismo, como influenciam, e de que forma, o futuro da identidade sócio-cultural do distrito de Lavras Novas.

Para isso, é necessário relembrar que o surgimento do turismo como principal atividade econômica em Lavras Novas é apenas um caso dentre os vários outros que ocorrem hoje, a nível global, de acordo com a superestrutura sistêmica ditada pelo capital. No atual panorama em que se enquadram pequenas comunidades, como Lavras Novas, o turismo se torna a única possibilidade econômica para a população.

Considerando a forma de apropriação das festas populares pela população local, bem como a forma como a comunidade administra seu território, e as análises feitas nos capítulos anteriores, fica claro que a população vem se conscientizando através da criação de espaços coletivos (ou mesmo do uso de espaços antigos, utilizados para outros fins inicialmente), para a discussão sobre a necessidade de valorizar seu modo de vida. Por meio da expansão da consciência nas discussões em grupo, a comunidade vem buscando, aos poucos, melhorar sua realidade. Pois, como afirma Marx, a consciência é um produto social:

"São os homens os produtores das suas representações, das suas idéias, etc; mas os homens reais agentes, tais como são condicionados por um desenvolvimento determinado das suas forças produtivas e das relações que lhes correspondem. A consciência não pode ser coisa diversa do ser consciente e o ser dos homens é o seu processo de vida real. (...) Desde o início que pesa uma maldição sobre «o espírito», a de estar «manchado» por uma matéria que se apresenta aqui sob a forma de camadas de ar agitadas, de sons, de linguagem em suma. A linguagem é tão velha quanto a consciência - a linguagem é a consciência real, prática, existente também para outros homens, existente também igualmente para mim mesmo pela primeira vez, e, tal como a consciência, a linguagem só aparece com a necessidade, a necessidade de comunicação com os outros homens. (...) A consciência é portanto, desde início, um produto social, e assim sucederá enquanto existirem homens em geral." (MARX, 1984: 38) 
Grupos responsáveis por apenas assuntos relacionados à assuntos religiosos, como é o caso da Irmandade Nossa Senhora dos Prazeres de Lavras Novas, passaram, com o tempo, a tomar consciência da importância de tratar assuntos relacionados ao turismo na região, mesmo porque as atividades turísticas vinham influenciando na execução das festas populares na comunidade, bem como a participação do povo nas mesmas.

Essa consciência surgiu da necessidade de mudança, pois o turismo incentivado pela mídia em seus moldes capitalistas não pressupõe respeito e igualdade, tem apenas como função a criação de produtos consumíveis, de locais vazios de cultura, autônomos, que sejam desfrutáveis e propiciem ainda mais consumo.

A partir dessa necessidade de mudança, houve a união entre a associação de moradores, entre comerciantes, e entre a irmandade, para juntos poderem discutir medidas que levassem a uma melhor convivência entre os turistas e a comunidade. Muitas destas medidas foram analisadas, discutidas e vêm realmente gerando resultados eficientes em Lavras Novas, possibilitando uma convivência menos conflitiva entre turistas e moradores.

Estão entre estas medidas: a preferência pela realização das festas em finais de semana que não coincidam com feriados (como é o caso de a semana da Festa do Divino e de Nossa Senhora dos Prazeres se dar próximo do dia 7 de setembro, feriado, e a comunidade priorizar sua realização em um final de semana antes ou depois deste feriado); a proibição da realização de eventos pelas grandes pousadas em períodos de festa religiosa; a proibição da realização de shows ao ar livre em finais de semana festivos; a obrigatoriedade de uma conversa entre donos de estabelecimentos comerciais e a comunidade antes da realização de eventos, etc.

Todas estas medidas foram tomadas a partir da conscientização da população de Lavras Novas. Uma espécie de retomada da identidade sócio-cultural da população, o que resultou na união do povo em associações e grupos que visam o desenvolvimento não predatório desta região.

Porém, a criação de espaço para discussão de questões relacionadas ao turismo e sua dupla relação com a economia e o cotidiano da comunidade, é relativamente recente. $\mathrm{O}$ distrito vem sendo explorado pelo mercado do turismo e exposto na mídia como pólo turístico há cerca de 30 anos e as discussões em grupo sobre assuntos relacionados a preservação cultural da comunidade e de suas festas começaram esparsas nos últimos 10 
anos, e se tornaram rotineiras a partir do ano de 2007 , ano da realização do festival de queijos e vinhos Safras Novas.

Como as propostas de melhorias no convívio entre população e turistas é recente, pode-se notar que a comunidade ainda está no início de uma transformação social, na qual alguns elementos são priorizados em detrimento de outros. Conforme já citado, as preocupações da comunidade se restringem ao número de turistas, na não interferência de eventos nas festas religiosas e na vida cotidiana dos lavra-novenses, o que já é um grande passo considerando o caráter recente da implantação de políticas para o turismo local.

Mesmo assim, ainda não existe uma valorização da cultura local intricada a maioria dos eventos turísticos. A música e dança tradicionais na comunidade são apresentadas somente em festas religiosas, tendo a própria comunidade como alvo. Os turistas podem assistir ensaios do grupo Nananã, na Casa de Cultura Dedela, mas este tipo de apresentação é excluído dos espaços referentes a eventos. As bandas locais, os instrumentistas da região ainda são substituídos com naturalidade pelos shows de rock e MPB, ao gosto dos turistas, não valorizando o que é natural de Lavras Novas.

Os causos e lendas da comunidade são relegados à inutilidade e substituídos, muitas vezes, por histórias fantasiosas sobre a formação do distrito, com o intuito de atrair turistas. $\mathrm{Na}$ maioria dos sites relacionados a serviços de hospedagem e a gastronomia, é comum tratar-se à comunidade como um antigo refúgio para negros fugidos, mesmo sabendo que a história do distrito está intrincada ao início da mineração e da escravatura em Minas Gerais.

Como afirmado no primeiro capítulo deste trabalho, remeter o surgimento de Lavras Novas a uma comunidade quilombola formada por negros fugidos, realmente cria uma aura de mistério sobre a localidade, atraindo turistas, porém, ao se apoiar a estrutura de formação histórica do local nesta inverdade, perde-se a oportunidade de conhecimento e criação de um turismo educativo na região.

Considerando a importância histórica da mineração no Brasil e em Minas Gerais, e que o distrito de Lavras Novas possui uma grande quantidade de locais e monumentos que fazem parte do Patrimônio Histórico Nacional (como minas desativadas remanescentes do final do século XVII; a Igreja de Nossa Senhora dos Prazeres e o Cruzeiro, que datam do início do século XVIII; uma imagem de Nossa Senhora dos Prazeres e casas restauradas que datam do mesmo período, além do patrimônio imaterial.), a possibilidade da criação de 
um turismo educativo é latente.

O desenvolvimento desta espécie de turismo, partindo do povo da comunidade, em parceria com o poder público, pode gerar lucros para a comunidade (pois os turistas fariam uso da infra-estrutura local) e também ajudar na preservação do patrimônio histórico de Lavras Novas, através da criação de medidas políticas para sua valorização. Valorização esta que pode surgir concomitantemente com a valorização da verdadeira história do povo local, de suas raízes e de suas tradições.

Entre a realidade e as possibilidades, pode-se dizer que Lavras Novas está procurando minimizar os elementos predatórios e indo rumo a um turismo emancipador, principalmente no que diz respeito às festas pesquisadas: Festa do Divino e de Nossa Senhora dos Prazeres, e a Encomendação das Almas.

É necessário entender que o turismo emancipador de que falamos aqui, se insere na lógica capitalista de mercado. Lógica esta que impossibilita uma perfeita harmonia entre a geração de lucro e a preservação da identidade sócio-cultural.

Por outro lado, muitas das propostas que falam em turismo emancipador parecem querer construir uma comunidade isolada do mundo globalizado e de seu modo de produção. Parecem querer transformar pequenas comunidades em vitrines observativas academicamente, como se fosse possível viver em isolamento. Esta visão é demasiado romântica, e negligencia o acesso à mídia e à globalização presente nas instituições de ensino. Limitar uma comunidade ao isolamento, corresponderia a eliminar seu poder de transformação e de troca, limitar a melhoria na qualidade de vida de sua população e a expansão de consciência dos moradores locais.

Ser banido do processo neoliberal, como foram, inicialmente, as pequenas, comunidades, criou uma forma alternativa de vida nestes locais, uma vida isolada e com escassez. Continuar vivendo no isolamento significaria para estar comunidades continuar vivendo na pobreza, sem acesso a educação e saneamento básico. O turismo, em comunidades como Lavras Novas trouxe visibilidade e melhorias para a população local e não deve ser tratado (devido a seus caracteres predatórios ainda presentes) como algo a ser extirpado ou não incentivado de nenhum modo. Deve ser tratado como uma atividade econômica que traz novas possibilidades e que deve ser administrada pela população local, de forma a não produzir deformações nas atividades sócio-culturais da comunidade. 
Assim, o trabalho de campo comprovou que a comunidade de Lavras Novas vem buscando transformar, aos poucos, o turismo predatório em turismo emancipador através da criação coletiva de políticas para um melhor convívio entre a comunidade, seus costumes, suas festas e os turistas.

Os dois objetos de estudo desta pesquisa, a Festa do Divino e de Nossa Senhora dos Prazeres e a Encomendação das Almas, convergiram para o entendimento das festas populares como promissores instrumentos de transformação e comunicação das classes subalternas, onde as alternativas construídas pela própria população em relação às festas populares, abrem caminho para novas esperanças em relação aos problemas ainda vividos em Lavras Novas. 


\section{REFERÊNCIAS BIBLIOGRÁFICAS}

ADORNO, T.W. A indústria cultural. In: Cohn, G. (Org.). Comunicação e indústria cultural. São Paulo: Nacional, 1978.

ADORNO, Theodor W. \& HORKHEIMER, Max. Indústria Cultural: o iluminismo como mistificação das massas. In: Almeida, Jorge M.B. "Indústria Cultural e Sociedade". Paz e Terra, 2002.

ADORNO. T. W. Experiências científicas nos Estados Unidos. In: ADORNO. T. W. Palavras e Sinais. Petrópolis: Vozes, 1995, p. 137 -178.

ANDRADE, M. de. Danças dramáticas do Brasil. São Paulo, Martins, 1966.

ANTONIL, A. J. Cultura e opulência do Brasil por suas drogas e minas. Belo Horizonte: Itatiaia; São Paulo: Edusp, 1982.

BAUMAN, Z.. Vidas Desperdiçadas. Rio de Janeiro: Zahar, 2005.

BARRETO, M. Turismo e legado cultural. 4. ed. Campinas: Papirus, 2003. 96 p.

BOURDIEU, P. A Economia das trocas simbólicas. São Paulo: Perspectiva, 1992.

BRECHT. B. O debate sobre o expressionismo. In: MACHADO. C. E. J. Um capítulo da história da modernidade estética: Debate sobre o expressionismo. São Paulo: Editora UNESP, 239 -266.

BOSCHI. C. C. Os leigos e o poder: as irmandades leigas e a política colonizadora em Minas Gerais. São Paulo: Ática, 1986.

CANCLINI, N.G, RONCAGLLOLO . Cultura Transnacional y Culturas populares. Peru: IPAL, 1988.

COELHO, T. O que é indústria cultural. São Paulo: Brasiliense, 1998.

Correio gourmet [22 de junho de 2010] (http://correiogourmand.com.br/default.htm)

Enciclopédia Larousse Cultural. Editora Nova:1995.

DIAS, Amarildo Ribeiro. A ideologia das classes subalternas através das festas. 2009, 202 p. Dissertação (Mestrado em Ciências da Comunicação). ECA-USP, São Paulo.

FERREIRA, M. N. Alternativas metodológicas para a produção científica. São Paulo. Celacc/ Eca/ USP. 2006.

-----. Comunicação, resistência e cidadania: as festas populares. Comunicação e Política, v. 24, p. 61-71, 2006.

-------. A festa como objeto de estudo: Uma introdução. Extraprensa: São Paulo -Celacc-ECA/USP, v. 8, n. outubro, p. 14-22, 2000.

-------. As Festas Populares na Expansão do Turismo: a experiência italiana. São Paulo: Arte\&Ciência, 2001. $111 \mathrm{p}$.

------. Globalizar a luta para globalizar a esperança. Comunicação e Política, Rio de Janeiro - R.J, v. 23, n. $03,2005$.

-------. Os antigos rituais agrários itálicos e suas manifestações na atualidade. Comunicação e Política, Rio de Janeiro, v. VII, p. 121-140, 2000.

-------. Os desafios da produção científica no neoliberalismo: As culturas e a comunicação subalterna. Comunicação e Política, Rio de Janeiro, v. 25, p. 101-120, 2006.

-------. Identidade cultural e turismo emancipador. São Paulo: Celacc/ECA/USP, 2005. 224 p.

-------. Globalização e Identidade Cultura na América Latina. São Paulo: CEBELA, 1995.

FOSTER, H. Leituras em resistência cultural. In: Foster.H. Recodificação: arte, espetáculo, política cultural. São Paulo: Casa Editorial Paulista, 1996. Cap 3. p. 209- 2.

Gomes. L.M.R, Guido. E.S, Ribeiro.A, Griffith. J.J.Turismo - Visão e Ação - volume 5 - n.3 -

set./dez. 2003

HALBWACHS, M. A memória coletiva. São Paulo: Vértice, 1990.

HALL, S. A Identidade Cultural na pós-modernidade. Rio de Janeiro:DP\&A, 2000.

----. Da Diáspora - Identidades e mediações culturais. Belo Horizonte: Editora UFMG, 2006. 410

p. 
LÉVI-STRAUSS, C. Mito e significado. Lisboa: Edições 70, 1978.

LÉVY, P. Os Três Tempos do Espírito: A oralidade primária, a escrita e a informática. In: LÉVY, P. As tecnologias da inteligência: Rio de Janeiro: Editora 34, 1994. p 75- 132.

LUKÁCS, G. Narrar ou descrever. In: LUKÁCS, G. Ensaios sobre literatura. Rio de Janeiro: Civilização Brasileira, 1968. p. 47 - 99.

------ . A arte como autoconsciência do desenvolvimento da humanidade. In: NETTO. J. P. Georg Lukács: Sociologia. Rio de Janeiro: Ática, p. 190 - 202.

-------. Introdução aos Escritos estéticos de Marx e Engels. In: LUKÁCS. G. Ensaios sobre a literatura. Rio de Janeiro: Civilização Brasileira, 1968, p. 13 - 45.

LUNA, F.V e COSTA, I. N. A Presença do Elemento Sudanês nas Minas Gerais. Suplemento Cultural do Jornal O Estado de São Paulo, São Paulo, ano II, no. 188, 26/11/1978, p. 14-16.

MARX, K. Para a crítica da economia política. São Paulo: Abril Cultural, 1982.

------. Manuscritos econômico-filosóficos. São Paulo: Boitempo, 2004.

------. A ideologia Alemã. Editora Moraes: São Paulo, 1984

MARTÍN-BARBERO, J. Dos meios às mediações: Comunicação, cultura e hegemonia. Rio de Janeiro: Editora UFRJ, 1997.

MEDEIROS, J. Elegia de utopias e mitos. Caros Amigos, Belo Horizonte, MG, n. 84, p. 42, 2004.

MELO, J. M. As festas populares como processos comunicacionais: roteiro para o seu

inventário no limiar do século XXI. Líbero: Revista Acadêmica de Pós-Graduação da faculdade de Comunicação Social Cásper Líbero. Ano III. Vol. 3, n.6, 2000.

MORAES FILHO, M. Festas e tradições populares no Brasil. Rio de Janeiro: Garnier, 1967.

MOURÃO, P. K. C. Matriz de Nossa Senhora dos Prazeres, de Lavras Novas, Ouro Preto. In: MOURÃO, P. K. C. As igrejas setecentistas de Minas. 3.ed. Rio de Janeiro: Itatiaia, 1986. Vol 3. p. 104.

MUKUNA, K. Contribuição bantu na música popular brasileira. São Paulo: Global, 1980.

NÚBIA P. M. Negras raízes mineiras: Os Arturos. $2^{a}$ ed. Belo Horizonte: Mazza: 2000.

ORTIZ. R. Pierre Bourdieu: sociologia. São Paulo: Ática, 1983.

OMT (2010) Disponível em <http//:www.world-turism.org>. Acesso em 25 de maio de 2010.

PAIVA, R. O Espírito Comum - comunidade, mídia e globalismo. Rio de Janeiro: Mauad,1998.

Prefeitura de Ouro Preto. Plano de inventário do acervo cultural de Ouro Preto: Secretaria Municipal de Cultura: 2005.

ROCHA, Everaldo P. G. O que é etnocentrismo. São Paulo: Brasiliense, 1987.

Ribeiro. D. Cultura e Alienação. In: Os brasileiros: Teoria do Brasil. Petrópoles: Vozes, 1983. p 81166.

Site Oficial de Lavras Novas [25 de maio de 2010] (http://www.lavrasnovas.com.br)

SILVEIRA, Emerson Sena da. Turismo e consumo: a religião como lazer em aparecida. In ABUMANSSUR, Edin Sued. (org.). Turismo religioso: ensaios antropológicos sobre religião e turismo. Campinas: Papirus, 2003, p. 69-106.

TÁRCIA. C. Jornal Santo de Casa. Ouro Preto: 1998, n.2.

TAVARES. J.C. Dicionário de Santos: hagiológico, iconográfico, de atributos, de padroados, de compositores, de música religiosa. Porto: Lello e irmãos editores, 1990.

-----. Jornal Santo de Casa. Ouro Preto: 2002, n.40.

-----. Jornal Santo de Casa. Ouro Preto: 2002, n.41.

------. Jornal Santo de Casa. Ouro Preto: 2003, n.43.

------. Jornal Santo de Casa. Ouro Preto: 2003, n.44.

------. Jornal Santo de Casa. Ouro Preto: 2003, n.45.

------. Jornal Santo de Casa. Ouro Preto: 2003, n.47.

------. Jornal Santo de Casa. Ouro Preto: 2003, n.48.

------. Jornal Santo de Casa. Ouro Preto: 2003, n.49.

------. Jornal Santo de Casa. Ouro Preto: 2003, n.51.

------. Jornal Vila Rica. Ouro Preto: 2005, n.131. 
VENANCIO, Renato Pinto. Os Últimos Carijós: Escravidão Indígena em Minas Gerais: 1711-1725. Revista Brasileira de História, São Paulo, v. 17, n. 34, 1997.

WILLIAMS, R. Palavras-chave: um vocabulário de cultura e sociedade. $1^{\text {a }}$ Ed. São Paulo: Bom Tempo, 2007.

WILLIAMS, R. Base e Superestrutura na Teoria Cultural Marxista. Revista USP, São Paulo, no 65, p.210-224, 2005. 
ANEXOS:

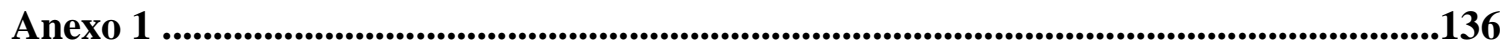

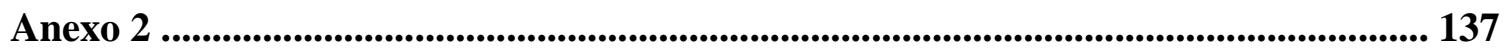

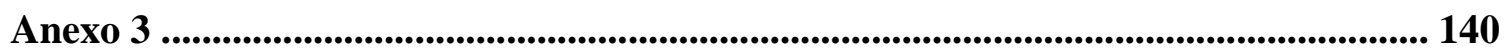

